E-COSMIC: A BUSINESS PROCESS MODEL BASED FUNCTIONAL SIZE ESTIMATION APPROACH

\author{
A THESIS SUBMITTED TO \\ THE GRADUATE SCHOOL OF INFORMATICS \\ OF \\ THE MIDDLE EAST TECHNICAL UNIVERSITY
}

BY

\begin{abstract}
MAHIR KAYA
IN PARTIAL FULFILLMENT OF THE REQUIREMENTS FOR THE DEGREE OF MASTER OF SCIENCE

IN

THE DEPARTMENT OF INFORMATION SYSTEMS
\end{abstract}

FEBRUARY 2010 
Approval of the Graduate School of Informatics

Prof. Dr. Nazife BAYKAL

Director

I certify that this thesis satisfies all the requirements as a thesis for the degree of Master of Science.

Assist. Prof. Dr. Tuğba TAŞKAYA TEMizEL

Head of Department

This is to certify that we have read this thesis and that in our opinion it is fully adequate, in scope and quality, as a thesis for the degree of Master of Science.

Assoc. Prof. Dr. Onur DEMIRÖRS

Supervisor

Examining Committee Members

Assist. Prof. Dr. Altan KOÇYiĞiT

(METU, II)

Assoc. Prof. Dr. Onur DEMIRÖRS

(METU, II)

Assist. Prof. Dr. Aysu BETIN CAN

(METU,II)

Dr. İdris DOĞAN

(DPT)

Dr. Selçuk GÜCEĞLiOĞLU

(BAŞBAKANLIK) 
I hereby declare that all information in this document has been obtained and presented in accordance with academic rules and ethical conduct. I also declare that, as required by these rules and conduct, I have fully cited and referenced all material and results that are not original to this work.

Name, Last Name: Mahir KAYA

Signature: 


\title{
ABSTRACT \\ E-COSMIC: A BUSINESS PROCESS MODEL BASED FUNCTIONAL SIZE ESTIMATION APPROACH
}

\author{
KAYA, Mahir \\ M.Sc., Department of Information Systems \\ Supervisor: Assoc. Prof. Dr. Onur Demirörs
}

February 2010, 120 pages

\begin{abstract}
The cost and effort estimation of projects depend on software size. A software product size is needed at as early a phase of the project as possible. Conventional Early Functional Size Estimation methods generate size at the early phase but result in subjectivity and unrepeatability due to manual calculation. On the other hand, automated Functional Size Measurement calculation approaches require constructs which are available in considerably late software development phases.
\end{abstract}


In this study we developed an approach called e-Cosmic to calculate and automate the functional size measurement based on the business processes. Functions and input and output relationship types of each function are identified in the business process model. The size of each relationship type is determined by assigning appropriate data movements based on the COSMIC Measurement Manual. Then, relationship type size is aggregated to produce the size of each function. The size of the software product is the sum of the size of these functions. Automation of this process based on business process model is performed by developing a script in the ARIS tool concept.

Three case studies were conducted to validate the proposed functional size estimation method (e-Cosmic). The size of the products in the case studies are measured manually with COSMIC FSM (Abran et al, 2007) as well as using a conventional early estimation method, called Early and Quick COSMIC FFP. We compared the results of different approaches and discussed the usability of e-Cosmic based on the findings.

Keywords: Early size estimation, Functional size measurement, Business process model. 


\title{
ÖZ \\ E-COSMIC: IŞ SÜRECI MODELI TEMELLI FONKSIYONEL BÜYÜKLÜK KESTIRIM YAKLAŞIMI
}

\author{
KAYA, Mahir \\ Yüksek Lisans, Bilişim Sistemleri Bölümü \\ Tez Yöneticisi: Doç. Dr.Onur Demirörs
}

Şubat 2010, 120 sayfa

\begin{abstract}
Projelerin maliyet ve işgücü kestirimleri yazılımın büyüklüğüne bağlıdır. Bir yazılım ürününün büyüklüğüne, projenin mümkün olduğu kadar erken bir safhasında ihtiyaç duyulur. Geleneksel erken büyüklük kestirim yöntemleri büyüklüğü erken aşamada bulmakta fakat elle hesaplamadan dolayı öznelliğe ve tekrarlanamayan sonuç üretimine neden olmaktadır. Diğer taraftan otomatikleştirilmiş FBÖ hesaplama yaklaşımları yazııım geliştirme safhalarının oldukça ileri aşamasındaki yapılara intiyaç duyarlar.
\end{abstract}

Bu çalışmada, iş sureçleri temel alınarak fonsiyonel büyüklük ölçümünü hesaplamak ve otomatikleştirmek için e-Cosmic olarak adlandırılan bir yaklaşım geliştirilmiştir. Iş süreç 
modelindeki fonksiyonlar ve her fonksiyonun girdi ve çıktı ilişki çeşitleri tanımlanmıştır. Her ilişki çeşidinin büyüklüğü, COSMIC ölçüm elkitabı temel alınarak uygun veri hareketleri atanması ile belirlenmiştir. Daha sonra, her fonksiyonun büyüklügünü bulmak için ilişki çeşitleri büyüklüğü toplanır. Yazılım ürünün büyüklüğü ise bu fonksiyonların büyüklüğünün toplamıdır. Bu sürecin, işsüreçleri modeli temel alınarak otomatikleştirilmesi ARIS aracında bir kod sayfası geliştirilerek gerçekleştirilmiştir.

Önerilen fonksiyonel büyüklük kestirim yönteminin (e-Cosmic) geçerlemesi için üç örnek olay incelemesi yürütülmüştür. Örnek olaylardaki ürünlerin büyüklüğü hem COSMIC FBÖ hem de Early and Quick COSMIC FFP olarak adlandırılan geleneksel bir erken kestirim modeli kullanılarak elle ölçüldü. Farklı yaklaşımların sonuçları karşılaştıııldı ve bulgular temel alınarak e-Cosmic yönteminin kullanılabilirliği tartışıldı.

Anahtar Kelimeler: Erken büyüklük kestirimi, Fonksiyonel büyüklük ölçme, İ̧̧ süreci modeli. 
To Yasemin Çetin 


\section{ACKNOWLEDGMENTS}

I wish to offer my sincere thanks and appreciation to my supervisor Assoc. Prof. Dr. Onur Demirörs for his precious help, invaluable suggestions, continuous support, guidance, criticisms, encouragements and patience throughout this study.

I would like to also express my special gratitude to Çağaçan Değer for his support and suggestions throughout my research.

I am very grateful to Özden Özcan Top, Ahmet Coşkunçay and Banu Aysolmaz for their support during the thesis study.

I would also like to thank my friends Murat Güneş, Anna Güneş, Ersin Karaman, Fatih Ömrüuzun, Rahime Belen, Yalın Baştanlar and Erdir Ungan for their friendship and encouragement.

I appreciate Ayşe Ceylan, Sibel Gülnar, Necla Işıklar and Ali Kantar in the institute for their kindness since the beginning of my M.Sc. study.

I will never forget the support of my friends Cansel Kadıoğlu, Evren Şumuer, Ali Sinan Dike and Murat Özkaptan.

I would like to express my deepest gratitude to my parents, my brother and my sisters for their love, encouragement, and support throughout my education.

Finally, special thanks to Yasemin Çetin, who endured this long process with me, for her continuous encouragement, infinite patience and moral support. 


\section{TABLE OF CONTENTS}

ABSTRACT OCZ

2.1. Software Size Measurement/Estimation Methods ................................................. 5

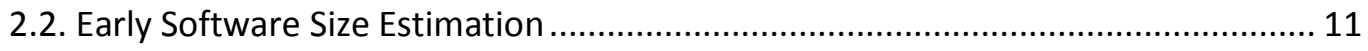

2.2.1. Jones Very Early Size Predictor....................................................................... 11

2.2.2. Standard Component Sizing ................................................................ 13

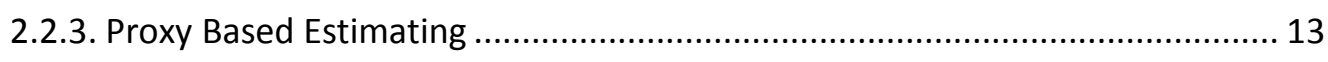

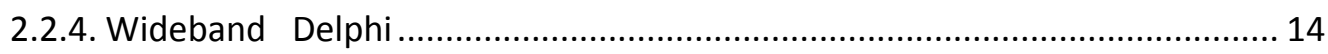

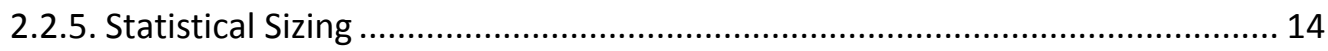




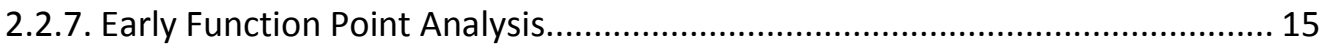

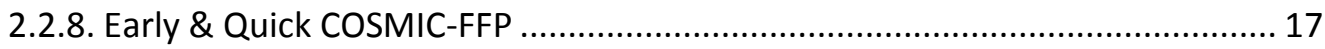

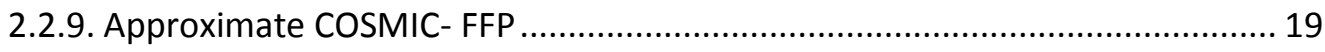

2.3. Software Size Automation Approaches............................................................ 19

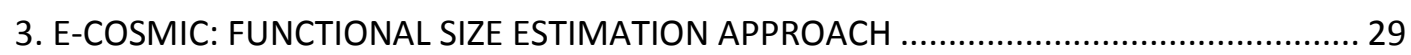

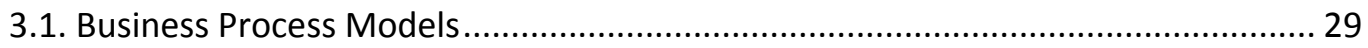

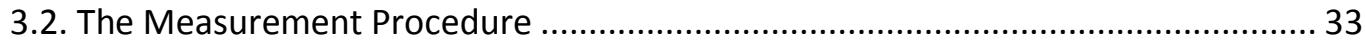

3.2.1. Functional Size Calculation Algorithm ............................................................ 35

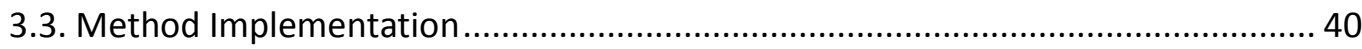

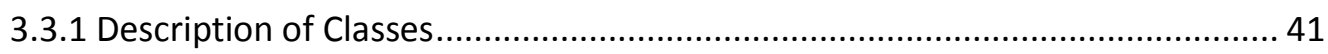

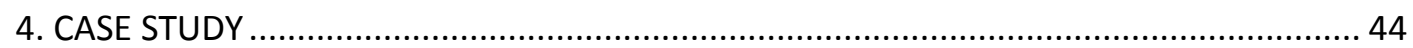

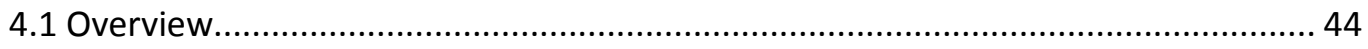

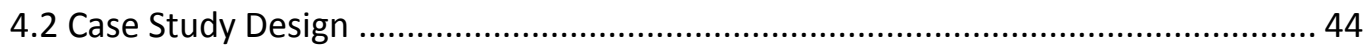

4.2.1 Case Study 1: Constructing e-Cosmic FSE method ................................ 47

4.2.2 Case Study 2: Comparing Estimation Methods .................................... 49

4.2.3 Case Study 3: Implementation of e-Cosmic FSE method ........................... 50

4.3 General Discussions on the Case Studies and the Results ................................. 51

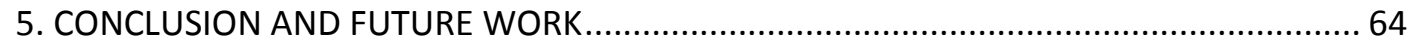

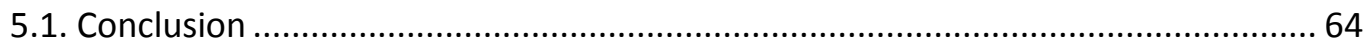

5.2. Future Work .................................................................................. 66

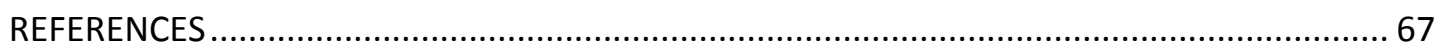

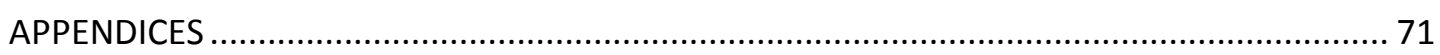

A. Business Process Model.............................................................................. 71

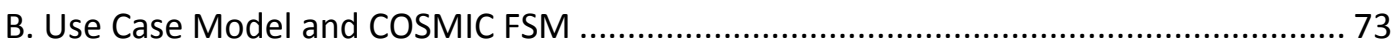




\section{LIST OF TABLES}

TABLE

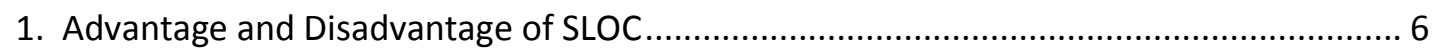

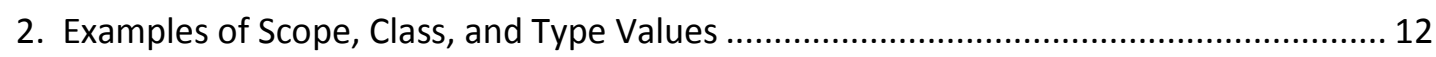

3. E\&QCFFP 2.0 elements ranges and numerical values.................................................... 18

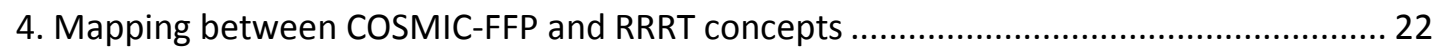

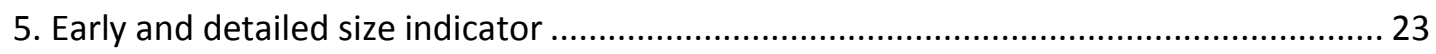

6. Comparison of proposals of the functional size automation........................................... 27

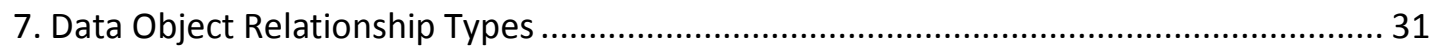

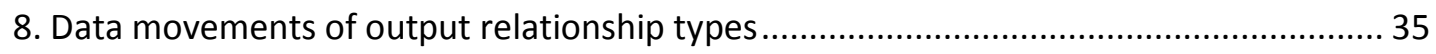

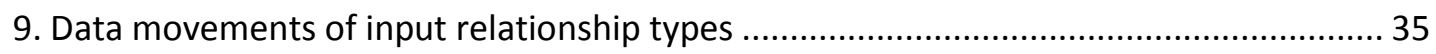

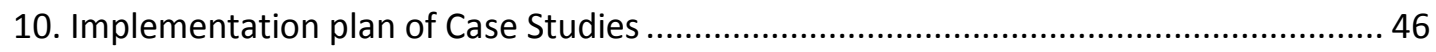

11. Summary of e-Cosmic FP of the "Extending Independent Auditor Pool"...................... 51

12. Cosmic Function Point of "Extending Independent Auditor Pool" by means of COSMIC

13. Update, delete, and list pattern for an entity. 54

14. Mapping of relationship types into data movements for "create IA selection criteria" 56

15. Mapping of relationship types into data movements for "update IA outputs" .............. 57

16. CFP count of each functional process for software products by e-Cosmic ..................... 58

17. Statistical analysis of the case studies with respect to size of the functional processes 59 18. Deviation between total functional sizes of the software products with respect to the methods 60 
19. Implementation of Early and Quick COSMIC FFP method on the case studies 61

20. Size estimates by Early and Quick COSMIC FFP and the deviations with respect to COSMIC FSM. 61

21. Effort values for COSMIC FSM and e-Cosmic. 62 


\section{LIST OF FIGURES}

FIGURE

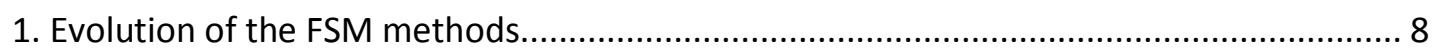

2. Data movement types and their relationship with software......................................... 10

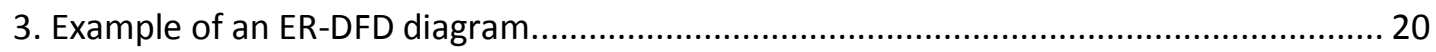

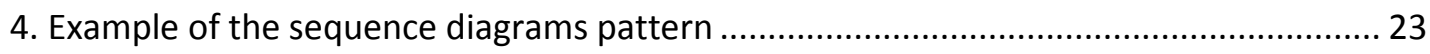

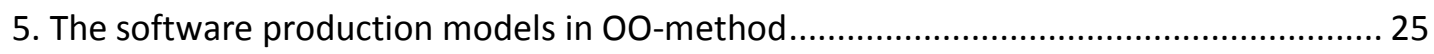

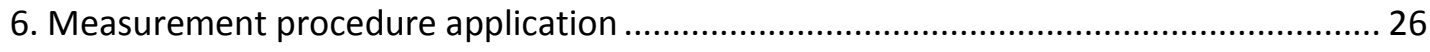

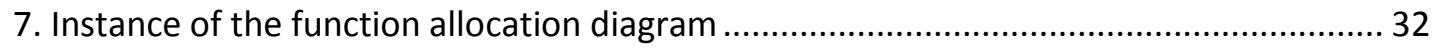

8. The main procedure of the e-Cosmic FSE method ........................................................ 37

9. The detail of the Identify Data Movement Type Step.......................................................... 38

10. The detail of the Identify Application System step ....................................................... 39

11. Function allocation diagram of "create IA selection criteria" ....................................... 56

12. Function allocation diagram of "update IA outputs" .................................................... 57

13. Estimation deviations between total functional sizes of the software products with

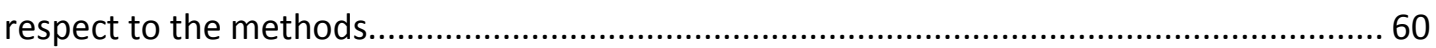

14. Comparison of the functional size of the software products with respect to the employed methods. 61 


\section{LIST OF ABBREVIATIONS AND ACRONYMS}

$\begin{array}{ll}\text { ARIS } & : \text { Architecture of Integrated Information Systems } \\ \text { BPM } & : \text { Business Process Modeling } \\ \text { CFP } & : \text { COSMIC Function Point } \\ \text { Cfsu } & : \text { COSMIC functional size unit } \\ \text { COSMIC } & : \text { Common Software Measurement International Consortium } \\ \text { COSMIC FFP } & : \text { COSMIC Full Function Point } \\ \text { CRUD } & : \text { Create Read Update Delete } \\ \text { DET } & : \text { Data Element Type } \\ \text { DFD } & : \text { Data Flow Diagram } \\ \text { E } & : \text { Entry } \\ \text { E\&Q COSMIC FFP } & : \text { Early and Quick COSMIC Full Function Point } \\ \text { E\&QCFFP } & : \text { Early and Quick COSMIC Full Function Point } \\ \text { eEPC } & : \text { Extended Event Driven Process Chain } \\ \text { EIAP } & : \text { Extending Independent Assessor Pool } \\ \text { EFPA } & : \text { Early Function Point Analysis } \\ \text { EFSE } & : \text { Early Functional Size Estimation } \\ \text { ER } & : \text { Entity Relationship } \\ \text { IA } & : \text { Independent Auditor } \\ \text { FAD } & : \text { Function Allocation Diagram } \\ \text { FBÖ } & : \text { Fonksiyonel Büyüklük Ölçümü } \\ \text { FFP } & : \text { Function Point Analysis } \\ \text { FP } & \text { FPA }\end{array}$




\begin{tabular}{|c|c|}
\hline FSM & : Functional Size Measurement \\
\hline FUR & : Functional User Requirement \\
\hline GP & : General Process \\
\hline IFPUG & : International Function Point Users Group \\
\hline ILF & : Internal Logical File \\
\hline LDG & : Logical Data Group \\
\hline LOC & : Lines of Code \\
\hline MDG & : Multiple Data Group, \\
\hline MIS & : Management Information Systems \\
\hline MP & : Macro Process \\
\hline NESMA & : Netherland Software Metrics Association \\
\hline $\mathrm{OO}$ & : Object Oriented \\
\hline OO-FPA & : Object Oriented Function Point Analysis \\
\hline $\mathrm{OOI}$ & : Object of Interest \\
\hline PM & : Problem Management \\
\hline PPP & : Perform Project Payments \\
\hline PROBE & : PROxy-Based Estimating \\
\hline PSP & : Personal Software Process \\
\hline $\mathrm{R}$ & : Read \\
\hline RRTT & : Rational Rose Real Time \\
\hline RUP & : Rational Unified Process \\
\hline Sfsu & : Scenario function size unit \\
\hline SLOC & : Source Line of Code \\
\hline SPR & : Software Productivity Research \\
\hline TP & : Typical Process \\
\hline Ufsu & : Use case function size unit \\
\hline UML & : Unified Modeling Language \\
\hline W & : Write \\
\hline$x$ & : Exit \\
\hline
\end{tabular}




\section{CHAPTER 1}

\section{INTRODUCTION}

Software industry continues to have problems related to project management. The major problems are related to difficulties of achieving high product quality and estimating effort and the time required for projects (Glass, 2003). The accuracy of size estimation is considered to be one of the most significant causes of management problems as estimated size is the basis of accurate effort prediction approaches.

It is at the beginning of the project when we most need the software product size in order to make a realistic effort prediction and a proper allocation of available time and resources. In addition to being the most reliable indicator of effort prediction models software size is frequently utilized by other quality measures to normalize and compare the process outcomes.

Among the various size measurement methods, the ones based on "functionality" are widely-used due to their earlier applicability in the software life cycle. Although "Line of Code" (LOC) based size estimation has some drawbacks, it had been widely used until Allan Albrecht introduced the idea of measuring a size of software by means of its requirements or functional specifications. Funtional size became a significant innovation since the method does not depend on the development environment and programming language of the software product (Symons, 2001). 
In earlier Functional Size Measurement (FSM) methods, generation of the functional size of a software product might have been varying depending on the assumptions of the measurer. It was heavily dependent on the way how the measurer maps the software requirements represented in natural language to the elements of the FSM method. Various FSM methods and a set of related standards have been proposed and published since the original size estimation method proposed by Albrecht (1979). Modern FSM methodologies such as COSMIC (ISO/IEC 19761, 2003a), IFPUG Function Point Analysis (ISO/IEC 20926, 2003b) and Mark II Function Point Analysis (ISO/IEC 20968, 2002) can be reliably applied after the requirement specification phase.

There are also various early functional size estimation methods (Meli, 1997; Santillo and Melli, 1998; Abran, Desharnais, Oligny, St-Pierre \& Symons, 2003; Conte, lorio, Meli \& Santillo, 2004; Galorath and Evans, 2006; Jones, 2007) that enable functional size prediction (in COSMIC, IFPUG or Mark II) earlier than the software requirements phase. Early functional size estimation methods entail a certain degree of subjectivity (Santillo and Meli, 1998). They are also frequently criticized of being unrepeatable and subjective (Vogelezang, 2005).

Functional size estimation starts with extracting Functional User Requirements (FURs) from software product requirements. However, researchers who worked on formalizing and automating function point measurement have been largely interested in extracting elements of FSM methods from the software artifacts such as Data Flow Diagrams (DFD), Entity Relationship (ER) Diagrams, State Diagrams and Object - Oriented Diagrams.

During the recent years, software size estimation from Object-Oriented Design artifacts has emerged as a good solution for software size estimation problems such as measurer dependency or subjectivity, low accuracy and reliability and high measurement costs (Diab, Koukane, Frappier \& St-Denis, 2005). In order to overcome these problems, considerable researches have been conducted on developing software size measurement algorithms and mappings for Object-Oriented Design artifacts (Poels, 2003; Diab et al., 2005; CondoriFernandez, Abrahao \& Pastor, 2007; Levesque, Bevo \& Cao, 2008). However, researchers 
have not reached to an agreement on a unified definition of Object-Oriented Design artifacts to be used for automation of software size (van den Berg, Dekkers \& Oudshoorn, 2005). Furthermore Object-Oriented Design artifacts needed for software size estimation might not be available in early phases of the software life cycle. Although most studies have used class diagram and sequence diagrams as input artifacts for automation of software size estimation, class and sequence diagrams may be available only considerably later during the software development process than the time when the functional size can be measured manually (Uemura, Kusumoto \& Inoue, 1999). Generation of these artifacts also requires one third of all project development effort (Meli, 1997). In addition, it has been observed that most FSM automation approaches could not make their algorithm compatible with the whole measurement procedure of a FSM method (Abrahao and Emilio, 2008).

It has been hypothesized that a solution for cost effective, early size measurement was to establish an approach to measaure functional size based on process model constructs.

Business process models are frequently developed during organizational process improvement studies or system analysis phases of information system development projects. In other words, these models are available before the requirement specification phase of a software development project.

In this study to overcome the reliability and subjectivity problems, a mapping between functional size estimation components and common business process model constructs was developed and to decrease the measurement costs, the counting process was automated. The mapping and automation algorithm were also integrated into the methodology called e-Cosmic.

In e-Cosmic, the business process model elements are mapped to the main components, "functional processes" of COSMIC FSM method (Abran et al, 2007) and components of functional processes are mapped to different types of externally observable relationship types that are represented as input to and output of activities of processes. An algorithm 
was defined to count the occurrences of those relationships. This algorithm was implemented in a specific process modeling environment called ARIS (Davis and Brabander, 2007).

In order to validate e-Cosmic functional size estimation method, three case studies have been conducted. The applicability of e-Cosmic functional size estimation approach was explored in the first case study. After refinements to the approach, second case study was conducted. During the second case study, a well known early functional size estimation method called Early and Quick COSMIC Full Function Point (Meli, Abran, Ho \& Oligny, 2000) was also implemented and the results were compared with e-Cosmic. Third case study was conducted to observe the deviations between COSMIC FSM results and estimation results.

In Chapter 2, a literature review on related subjects is presented and discussed. COSMIC FSM method which is used as a base model is described in this chapter. In addition, early functional size estimation methods and FSM automation approaches available in the literature are summarized and compared.

In chapter 3, e-Cosmic estimation methodology is explained. Mapping between the concepts of the process model constructs and the COSMIC FSM is detailed.

In chapter 4, we described the case studies that we have performed to validate e-Cosmic Functional size estimation method.

In chapter 5, significance and contributions of the study are presented and suggestions for future work are provided. 


\section{CHAPTER 2}

\section{RELATED RESEARCH}

This chapter presents the results of the literature review on software size measurement/estimation methods, early software size estimation approaches and automation approaches of software functional size measurement.

\subsection{Software Size Measurement/Estimation Methods}

Since the early computer era of 1940s, software size measurement has been a prominent but difficult activity. Software size is necessary to make a reliable project plan and properly allocate time and resources. In addition, size may help post-assessment about development effort by providing feedback on quality and productivity, on which various software measures depend.

There has been considerable research in the literature on the accurate and complete estimation of software size. These various approaches can be classified as technologyindependent methods such as Function Point Analysis (FPA) method and technologydependent methods such as LOC or number of classes.

Although counting program code is the oldest method and is used widely, the debate on how good it represents the size of software has come into prominence. In addition, there is not a consensus on definition of the measurement procedure such as counting comment line or only executable statements. The advantages and disadvantages of the LOC are shown in Table 1 (Galorath and Evans, 2006). 
Table 1: Advantage and Disadvantage of SLOC

\begin{tabular}{|c|c|}
\hline Advantage & Disadvantage \\
\hline Easy to compute & It heavily depends on how code is written \\
\hline Intuitive & Multiple definitions for what constitutes a line of code. \\
\hline Granular & Varies dramatically based on technology used \\
\hline \multirow[t]{2}{*}{ Natural by-product of process } & It becomes available at the end of the development. \\
\hline & Some languages difficult to count automatically \\
\hline
\end{tabular}

In the late 1970s, in order to overcome deficiencies of source code based approaches, Albrecht (1979) proposed a method based on measuring amount of functionality delivered to user. The size is measured from a functional, or user, point of view. The Function Point technique is independent of the computer language, development methodology, technology or the capability of the program developers. Symons (2001) stated that "At the time it was a genuine breakthrough in thinking by providing the first method for sizing software which was independent of the technology to be used for its development" (Symons, 2001: p413).

Albrecht's model counts software product in terms of four characteristics; namely External Inputs and Outputs, User Interactions, External Interfaces and Files used by the system. After identification of these types of components in a specification, they are weighted from 3 (simple) to 15 (complex). The Function Point Method has evolved and got refined in course of time. The result of these refinements is the "counting manual" produced by IBM in the early eighties. International Function Point Users Group (IFPUG) was formed in 1986. This organization produced its own Counting Practices Manual to clarify and standardize rules for the application of FPA. Since the first publication of IFPUG FPA, each release of these IFPUG publications has provided refinements to the technique originally presented by Albrecht. The IFPUG (Release 4.2) was published in 2005.

There are four functional size measurement methods that are certified by ISO/IEC. These are IFPUG FPA, Mark II FPA, Netherland Software Metrics Association (NESMA) FPA and 
COSMIC FFP. NESMA and IFPUG methods are alike and Mark II method is used less frequently (van den Berg et al, 2005). The history of FPA methods are shown in Figure 1 (Levesque et al, 2008). The detailed discussion of differences between FPA methods, and their evolutions are out of the scope of this thesis. COSMIC, details of which is given later in this section, is selected as FPA method in this thesis study because of the fact that it is easy to apply, suitable for MIS applications, has a measurement procedure more appropriate for counting business process model and the definition of entity attributes is not required for counting. 


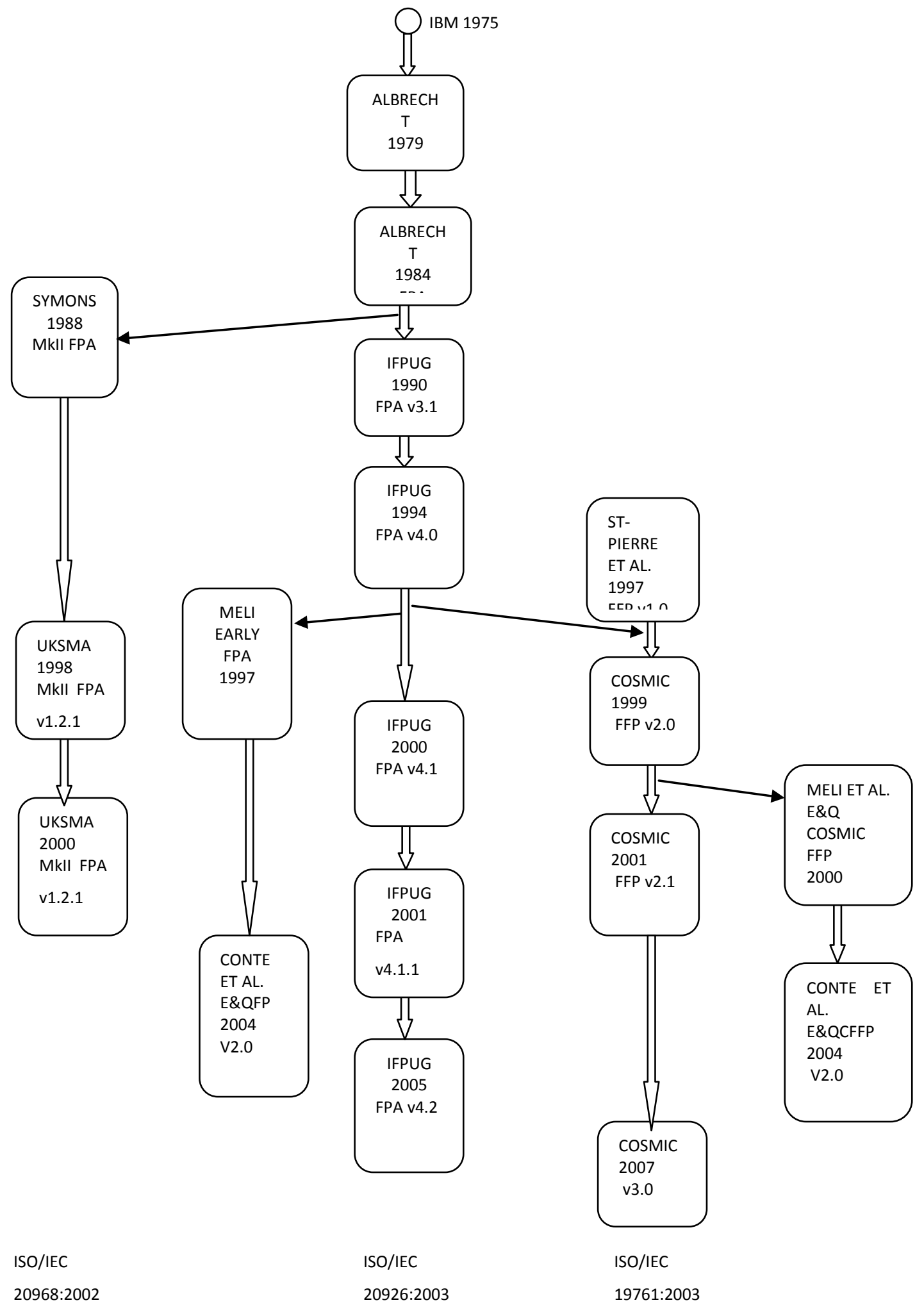

Source: Based on Levesque et al. (2008), edited by the author

Figure 1: Evolution of the FSM methods 
The COSMIC FSM method is accepted as a second generation size measurement method. The word "COSMIC" stands for "Common Software Measurement International Consortium". The COSMIC Function Point method evolved from "Full Function Point" method coupled with some aspects of Mark II function point (Jones, 2008). A group of software metrics experts established COSMIC in 1999 (Abran, 1999). It has been improved and new versions have been released since then.

The COSMIC method was designed as a standardized method of measuring a functional size of software from the functional domains that are business application (or MIS) software and real-time software (Abran et al., 2007). The functional size of any component of software can be measured as seen by direct users of that component. On the other hand, it has not been suitable for measuring complex mathematical algorithms such as expert systems and simulation systems. In addition to this, it does not take into account neither the influence of complexity arising from technology nor the influence of the number of data attributes per data movement on software functional size.

The measurement process of the method includes three phases: the measurement strategy, the mapping of the concepts and the measurement phase that represents value assignments. In the first phase, the purpose and the scope of the measurement must be identified. Then, functional users, which send or receive data to or from the functional process, must be identified. FURs must be extracted from software artifacts. Finally, the "levels of granularity" should be identified in the beginning of the measurement. Scope and purpose affect software size in terms of both "user viewpoint" or "developer viewpoint" and entry-exit pair across the boundary. These terms also help determining the boundary of the application.

In the mapping phase, functional processes, which are elementary components of a set of FURs, must be identified. It comprises a unique, cohesive and independently executable set of data movements. Functional user triggers the functional process by an entry data movement. Then, the data group and the object of interest (OOI) should be determined. A data group is a set of data attributes that are distinct, non empty, unordered and non 
redundant. OOIs can be any "entity" which is related with FURs. It is optional to define attributes of a data group (Abran et al., 2007).

In the measurement phase, the data movements for each functional process should be identified. Data movements are the Entries, eXits, Reads and Writes crossing the boundary between the functional user and the application (ISO/IEC, 2003a). A visual representation can be seen in Figure 2. After identification of all data movements, we can apply measurement function as assigning 1 CFP to each data movement of the functional process, when all functional processes are aggregated, the functional size of the measured piece of the software is generated.

The data movements are described as follows:

- An Entry (E) is a movement of a data group from the user's side of the boundary to the inside of the boundary

- An Exit $(X)$ is a movement of a data group from inside the boundary to the user side.

- A Read $(R)$ is a movement of a data group from the persistent storage to the functional process which requires it.

- A Write (W) is a movement of a data group from the functional process to the persistent storage.

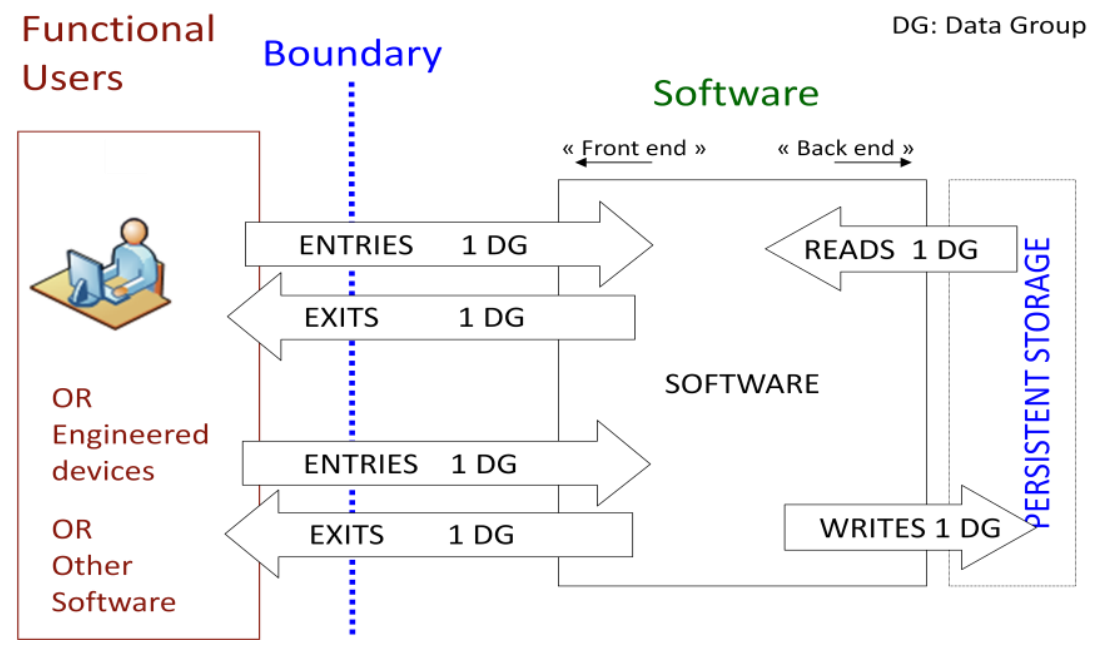

Source: Based on Abran et al. (2007), edited by the author

Figure 2: Data movement types and their relationship with software 


\subsection{Early Software Size Estimation}

The most important advantage of FSM methods is their usability when FURs of business application are defined. However, project managers also need a method for planning and managing the tasks of the requirements phase as requirement specification tasks comprises from $15 \%$ to $40 \%$ of the total work effort (Meli, 1997).

In order to overcome this problem a few techniques for early functional size estimation are developed. In this section we will describe each early functional size estimation method to represent their applicability. Strengths and weaknesses of them will be identified.

\subsubsection{Jones Very Early Size Predictor}

This is an estimation method developed by Capers Jones. Jones (2007) tried to transform function point metric from sizing a very difficult task into one that is now not only easy to apply but comparatively accurate as well.

Most software cost estimating tools need to identify the project in terms of scope, class and type. The method utilizes taxonomy for defining software projects. Early size approximation of function points are produced by utilizing this project identification mechanism. Although this basic method of sizing is far from producing reliable results for serious cost estimating purposes, if we do not have enough information about the project it emerges as a good solution to find project size. The examples of the scope, class and type of taxonomy for guessing at the approximate size of the software are depicted in Table 2.

In order to apply this superficial sizing method, we firstly identify numeric list values of the project in terms of scope, class, and type factors and then apply the following formula proposed by Jones (2007):

Size $=(\text { Scope }+ \text { Class }+ \text { Type })^{2.35}$ 
Table 2: Examples of Scope, Class, and Type Values

\begin{tabular}{|c|c|c|}
\hline Scope: & Class: & Type: \\
\hline 1) Subroutine & 1) Individual software & 1) Nonprocedural \\
\hline 2) Module & 2) Shareware & 2) Web applet \\
\hline 3) Reusable module & 3) Academic software & 3) Batch (not database) \\
\hline 4) Disposable prototype & 4) Single location - internal & 4) Interactive \\
\hline 5) Evolutionary prototype & 5) Multi location - internal & 5) Interactive GUI or web -based \\
\hline 6) Standalone program & 6) Contract project - civilian & 6) Batch database \\
\hline 7) Component of a system & 7) Time sharing & 7) Interactive database \\
\hline 8) Release of system & 8) Military services & 8) Client/server \\
\hline 9) New system & 9) Internet & 9) Mathematical \\
\hline \multirow[t]{11}{*}{ 10) Compound system } & 10) Leased software & 10) Systems \\
\hline & 11) Bundled software & 11) Communications \\
\hline & 12) Marketed commercially & 12) Process control \\
\hline & 13) Outsource contract & 13) Trusted system \\
\hline & 14) Government contract & 14) Embedded \\
\hline & 15) Military contract & 15) Image processing \\
\hline & & 16) Multimedia \\
\hline & & 17) Robotics \\
\hline & & 18) Artificial intelligence \\
\hline & & 19) Neural net \\
\hline & & 20) Hybrid: mixed \\
\hline
\end{tabular}

Source: Based on Jones (2007) 
This rough approximation method gives a limited size value. If we use the highest numeric list values of scope, class, and type, the maximum size of a project may be approximately 7675 FP. According to this value, we would conclude that the method is not suitable for large software projects. However this approximation method is enough to see whether an application will be a trivial one. In addition, Jones (2007) suggested that this taxonomy would be suitable for other metrics such as object points, CFPs, or engineering function points by using the proper power for formula. Since this empirical formula utilizes only a fundamental taxonomy to try to find applications with similar patterns, it can be applied on thousands of projects in existence to come up with appropriate power for specific projects.

\subsubsection{Standard Component Sizing}

Standard component sizing depends on identification of a number of key components and then comparison to the collected past data related to this key components (Vogelezang, 2005). An estimation of average and extreme size for key components can be produced by comparison of historical data on similar components, so data of previous projects is required to apply the method. Another method suggested by Putnam and Myers relies on Fuzzy logic concepts.

Fuzzy logic is used as a systematic way to perform comparison with past work. It was used by Putnam and Myers for software sizing purposes after adaptation to this field. According to the project size, systems built previously are divided into six sub-categories. In order to represent quartiles, four ranges are created within each size category. A new information system is compared to the past projects, thus depending on the expert opinion the size of the new system can be estimated (Vogelezang, 2005).

\subsubsection{Proxy Based Estimating}

PROxy-Based Estimating (PROBE) method has evolved from the similarity based approach. Referring to Humphrey (1995), Vogelezang (2005) states that if a component needed to be developed is similar to the one built previously, the result of its software metrics will resemble to the previously completed work. 
Historical data is needed to apply the method. A size range is assigned to each conceptual function. In order to estimate size and effort in the Personal Software Process (PSP) which is a discipline that enables software engineers to monitor, test, and improve their own work, PROBE method can be used.

In the PROBE method, individual engineers break down past works into individual components. A type such as data or logic is identified for each component and then from very small to very large a size is counted and assigned to each component. Before a new project is started and determined a resource allocation, the size estimation of the project must be finished. The project is firstly separated into tasks according to the types and sizes and then a formula is applied in order to estimate size.

\subsubsection{Wideband Delphi}

Software size estimate mostly needs judgment of the estimator. Lacking rigor, this process may sometimes generate biased results about size of the software product (Galorath and Evans, 2006). In order to eliminate these disadvantages, one can apply Delphi estimation method. That is based upon software size estimations of expert teams and individuals. These groups and individuals start with the same description of the task and produce estimates anonymously. The average size is calculated based on estimation of the experts by a moderator and this average and all other estimates are given to the experts in order to repeat estimation. This process is repeated until the estimates get close enough and a consensus is reached (Boehm, 1981). In addition, this method might take much time to agree on a size; on the other hand, experts may not reach a consensus.

\subsubsection{Statistical Sizing}

The method relies on asking questions to the developer in order to determine a range of potential sizes that is classified by "least", "likely", and "most" (Galorath and Evans, 2006). In this method, estimator prepares a questionnaire to handle all expected and unanticipated situations during the development phase of the software product. 
The questions are asked to the developer consecutively since the order of the question is important. The initial question most likely would be that "what do you think the size of the software product will be". Then, other questions are designed according to capturing all of the risk related to the product. The classification of the results is depicted as follows:

- Least $=$ " What is the best case size?"

- Likely ="What is the expected size?"

- $\quad$ Most ="What is the worst case size?"

Galorath and Evans (2006) determined a formula in order to apply statistical sizing method as follows:

Expected value $=[$ Least $+(4 *$ Likely $)+$ Most $] / 6$

Standard deviation $=$ Most - Least

Expected size for any probability level can be calculated by using the standard deviation and "bell curve" probability table. This method is also known as Three-point estimation technique (Meli and Santillo, 1999).

\subsubsection{FPA}

This method is structured from many approaches so as to estimate the functional size of the software product (Vogelezang, 2005). Not only does this method benefit from some feature of the fuzzy logic and standard-component sizing but it is the adjusted convergence midpoint of the Delphi method and Early and Quick FPA method. Weight factors of the requirements are assigned by estimators in this approach. Then, a minimum, an average, and a maximum estimate values are determined for each weight factor. When we compare this method to the Early and Quick FPA and Delphi method, this method is less complex than Early and Quick method and it needs less time than Delphi method.

\subsubsection{Early Function Point Analysis}

Early Function Point Analysis (EFPA) method was introduced in 1997 (Meli, 1997), and then it is refined and exemplified by Santillo and Meli (1998). Early Function Point technique is not perceived as alternative measurement method to the FPA method since it is developed 
to produce a fast and early estimate as compared to the FPA (Meli, 1997). The measurement procedure of the method is based on using both analogical and analytical classification of functionalities. As considering this approach, we can see that the method produces better software product estimation compared to previously covered approaches.

The method allows estimators to identify software objects, which are composed of logical data and functionalities aspects, at different levels of detail. This aspect makes the method more robust because it is easy to increase detailed level of the software application brunch that is previously produced; on the other hand, little or nothing may be known about another software branch that is completely innovative (Santillo and Meli, 1998). The method enables estimators to use all information about the software application by supporting the different detail level of the software objects. There is a minimum, an average, and a maximum estimate for each type of object. Early \& Quick IFPUG Function Point (E\&QFP 2.0), which is an evolution of this technique, was released in 2004 (Conte et al., 2004). The technique is performed through statistically and analytically validated tables of values. There are 6 software objects in E\&QFP 2.0. From high level to low level, these objects are macro process, general process, typical process, functional process, multiple data group and logical data group. Macro process is a set of two or more average general processes. A general process contains a set of two or more average functional processes. The methodology defines a functional process as the elementary processes of the standard FPA. A typical process is a particular case of general process composed of "create, read, update, delete" (CRUD) and list (L) operations. Finally, logical data groups are presented to be a group of logical data attributes. Multiple data groups consist of a set of two or more logical data groups.

A set of size values based on statistical/analytical tables is determined for each software object, and then these values are summed in order to find the overall result (Conte et al., 2004). These methods rely on the estimator's ability to identify and assess the software objects accurately and completely. Therefore, this situation increases the subjectivity of the method. 


\subsubsection{Early \& Quick COSMIC-FFP}

In order to extend software domain of the EFPA method, EFPA research group has designed E\&Q COSMIC FFP based on present COSMIC FFP (Abran et al., 2003) principles. Such an extension was needed for EFPA was based on IFPUG FPA, which is suitable mostly for MIS domain and thus requires a domain expansion.

Meli et al. (2000) stated that Early \& Quick estimation must not be perceived as an accurate measure of the software functional size, but only an estimation of that measure allowed to be produced for a wide range of software at early stages of the development life cycle. E\&Q COSMIC FFP 2.0 is released as a new proposal of the first version (Conte et al., 2004).

In order to apply the measurement procedure of the COSMIC FFP, a new software product has to be represented according to the software breakdown structure (Meli et al., 2000). The software product is decomposed towards finding a single node consisting of unique and ordered set of data movements in the function tree and then accepting those leaves as an input for measurement process to produce final size for the software item under measurement. On the other hand, in the early stages, it is not possible to distinguish the single data movements because of the fact that detailed level of information is not available. Thus, forecasts of average process size, at the intermediate and top levels, are assigned. Then, final result is produced by aggregating the intermediate results. Moreover, the size of functional process in the COSMIC FFP is not bounded as E\&Q COSMIC FFP. The component ranges and the numerical assignment for the E\&Q COSMIC FFP 2.0 Release Candidate is represented in Table 3. But it should be noted that this technique also entails a certain degree of subjectivity as EFPA does. 
Table 3: E\&QCFFP 2.0 elements ranges and numerical values

\begin{tabular}{|c|c|c|c|c|c|}
\hline Type & Level & Ranges / COSMIC Equivalent & $\begin{array}{l}\text { Min. } \\
\text { CFSU }\end{array}$ & $\begin{array}{l}\text { Most } \\
\text { likely } \\
\text { CFSU }\end{array}$ & $\begin{array}{l}\text { Max. } \\
\text { CFSU }\end{array}$ \\
\hline \multirow{4}{*}{$\begin{array}{l}\text { Functional } \\
\text { Process }\end{array}$} & Small & 1-5 Data movements & 2.0 & 3.9 & 5.0 \\
\hline & Medium & 5-8 Data movements & 5.0 & 6.9 & 8.0 \\
\hline & Large & 8-14 Data movements & $\begin{array}{l}8.0 \\
10.5 \\
14.0\end{array}$ & $\begin{array}{l}8.0 \\
10.5 \\
14.0\end{array}$ & $\begin{array}{l}8.0 \\
10.5 \\
14.0\end{array}$ \\
\hline & $\begin{array}{l}\text { Very } \\
\text { Large }\end{array}$ & 14+ Data movements & 14.0 & 23.7 & 30.0 \\
\hline \multirow[t]{3}{*}{$\begin{array}{l}\text { Typical } \\
\text { Process }\end{array}$} & Small & $\begin{array}{l}\text { CRUD (Small/Medium processes); } \\
\text { CRUD + List (Small processes) }\end{array}$ & 15.6 & 20.4 & 27.6 \\
\hline & Medium & $\begin{array}{l}\text { CRUD (Medium/Large processes); } \\
\text { CRUD + List (Medium processes); } \\
\text { CRUD + List }+ \text { Report (Small } \\
\text { processes) }\end{array}$ & 27.6 & 32.3 & 42.0 \\
\hline & Large & $\begin{array}{l}\text { CRUD (Large processes); } \\
\text { CRUD + List (Medium/Large } \\
\text { processes); } \\
\text { CRUD + List + Report (Medium } \\
\text { proc's) }\end{array}$ & 42.0 & 48.5 & 63.0 \\
\hline \multirow{3}{*}{$\begin{array}{l}\text { General } \\
\text { Process }\end{array}$} & Small & 6-10 generic FP's & 20.0 & 60.0 & 110.0 \\
\hline & Medium & 10-15 generic FP's & 40.0 & 95.0 & 160.0 \\
\hline & Large & 15-20 generic FP's & 60.0 & 130.0 & 220.0 \\
\hline \multirow{3}{*}{$\begin{array}{l}\text { Macro } \\
\text { Process }\end{array}$} & Small & 2-4 generic GP's & 120.0 & 285.0 & 520.0 \\
\hline & Medium & 4-6 generic GP's & 240.0 & 475.0 & 780.0 \\
\hline & Large & 6-10 generic GP's & 360.0 & 760.0 & $1,300.0$ \\
\hline
\end{tabular}

Source: Based on Conte et al. (2004) 


\subsubsection{Approximate COSMIC- FFP}

This technique is based on using an average value produced from previous software applications for the size of a functional process. An approximate version of the COSMICFFP method was designed in order to generate a software size estimation at an early phase of the software development process, when information needed to produce a size estimate by means of the detailed rules in the Measurement Manual is not available (Abran et al., 2003). The main aim of this method is to create a concept at a higher level of abstraction than the Data Movement, and then functional process is defined as first higher level abstraction. The size estimation of an application is produced by multiplying the quantity of the functional processes by the average size of a functional process. Subsequent COSMIC (2007) measurement manual excluded this section from the context. However, conducted literature review has failed to identify the reason for this exclusion.

\subsection{Software Size Automation Approaches}

In this section, we present the automation approach on measurement procedure of the FSM methods. During the literature survey, we identified a number of attempts to automate measurement procedure of the FSM methods by means of the software models. Ever since the first FPA method was introduced, it has evolved continuously and new methods were proposed. All of these methods define software size estimation procedure in a descriptive way that lacks a formal foundation (Fetcke, 1999). Many researchers have tried to translate the informal counting rules expressed in natural language that lacks formalization (Lamma, Mello \& Riguzzi, 2004). Fenton and Pfleeger (1997) defined the importance of the rules in terms of support for consistency in measurement and provision of a basis for interpreting data.

It is important to make automation of the function point measurement possible so as to produce consistent measurement results with minimum effort (Uemura et al., 1999). Automation of the measurement procedure enables support measurement repeatability, reductions in measurement variance, removes estimator's dependency and estimator's need for advanced measurement training and eliminates measurement related costs. 
Marin, Giachetti \& Pastor (2008) conducted a comprehensive survey on measurement process approaches that use conceptual models. This survey indicated eleven proposals of functional size measurement procedures based on COSMIC FSM. This survey has been one of the most important and detailed survey on measurement process proposals so far. In addition to these, we have examined other proposals such as Fectke et al. (1997), Lamma et al. (2004), Rask (1991), Poels (2003), Uemura et al. (1999), van den Berg et al. (2005), Hericko et al. (2006) and Diab et al. (2005). Hericko et al. (2006) also criticized the proposals of Fetcke et al. (1997), Uemura et al. (1999). We selected nine proposals for detailed explanation in order to represent differences of the models.

\section{Proposal of Lamma et al. (2004)}

A knowledge based approach for the automated measurement of the Function Point metrics is proposed by integrating ER diagram and DFD. FPA method rules were specialized according to the ER-DFD model. Proposed model is implemented in Prolog that automatically counts Function Point by analyzing the graph. The example graph is depicted in Figure 3.

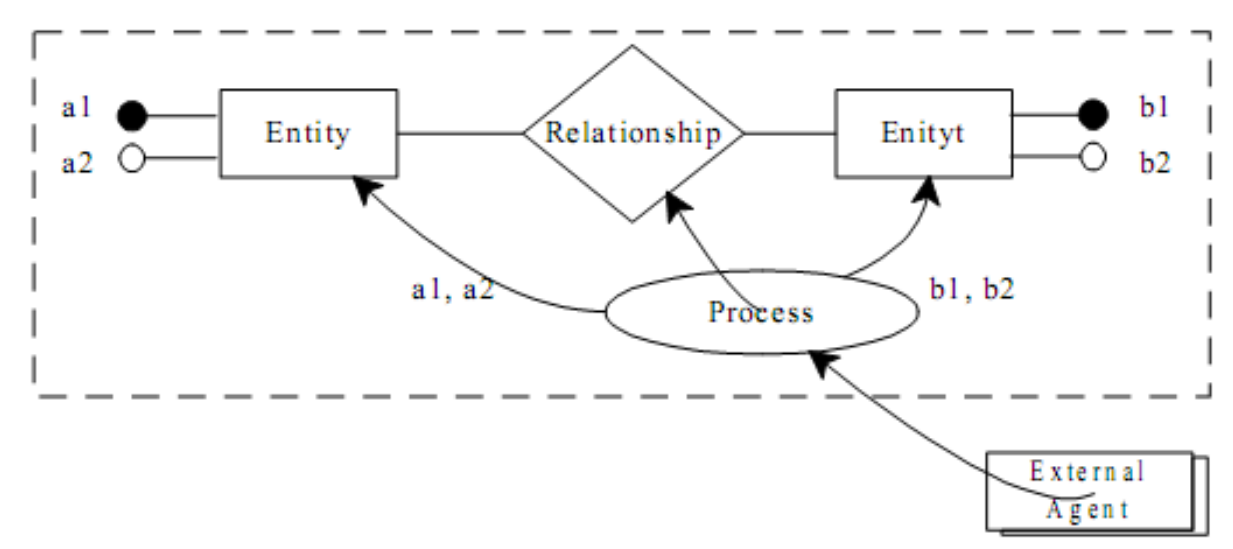

Source: Based on Lamma et al. (1997)

Figure 3: Example of an ER-DFD diagram.

Formal rules for counting Function Points on ER-DFD are identified. Every process in the model is defined as an elementary process of the FPA method, every attribute of an entity is accepted as Data Element Type (DET), and the direction of arrow between entity and process of DFD represents the transaction type such as EI, EO, or EQ. This model has not 
been accepted widely because of the fact that conceptual model representation of the software products has already transformed to the object oriented area. In addition to this, Rask (1991) proposed algorithms to generate function points from DFD.

\section{Proposal of Bevo et al. (1999) and Jenner (2001)}

The characteristics of these proposals are very similar. Both of them present a mapping between COSMIC FFP concepts and Unified Modeling Language (UML) based specifications. Bevo et al. (1999) used diagrams of use cases, scenarios, and classes as input artifacts but proposal of Jenner (2001) differs from previous work in terms of using sequence diagrams instead of scenarios which are sequence of interactions that occur inside a use case. This difference shows its effect in granularity level of use cases. Bevo et al. (1999) defined a mapping between use cases and COSMIC FFP functional processes. The boundary of the system is represented as a use case diagram. While scenarios represent data movements, a data group is represented as a class. The attributes of those classes constitute attributes of a data group. Each actor of the UML notations represents functional user. On the other hand, Jenner (2001) argued that a mapping of use cases on to functional processes may include some shortcomings. Jenner (2001) provided appropriateness of accepting a sequence diagram for each use case and each use case as a sequence of functional process, states Marin (2008). Poels (2002) introduced this conflict that is raised between Bevo et al. (1999) and Jenner (2001) as well.

\section{Proposal of Diab et al. (2005)}

Diab et al. designed a software tool named $\mu$ CROSE in order to automate functional size estimation of real time applications for Rational Rose Real Time (RRRT) models. The ROOM charts used for input are a type of state chart diagram. The model consists of a set of formal rules. The RRRT model has two different viewpoints such as structure and behavior. The structure of an RRRT is composed of capsules, protocols, and data classes. A capsule is an active entity. A protocol represents a set of possible messages exchanged between capsules. And the dynamic aspects of each capsules is specified with extended finite state machine. Table 4 depicts the correspondence between COSMIC-FFP and RRRT concepts. 
Table 4: Mapping between COSMIC-FFP and RRRT concepts

\begin{tabular}{ll}
\hline COSMIC-FFP concepts & RRRT concepts \\
\hline Layer & Set of capsules \\
Boundary & Conceptual boundary of a set of capsules \\
Data Group & Message or a data type \\
Functional Process & One or several transitions \\
\hline Triggering event & Arrival of an external message \\
Data movements & Actions and messages \\
\hline
\end{tabular}

Source: Based on Diab et al. (2005)

It is the first tool to provide automatic measurement of COSMIC FFP. The validation phase of the $\mu$ CROSE with an expert emerged as an important behavior of the COSMIC-FFP. One of them is that $\mu \mathrm{CROSE}$ identifies one data group for all simple attributes of a capsule; however, the expert identifies one data group per simple attribute of a capsule. We want to indicate that the number of data groups determines the number of data movements (Entry, eXit, Read, Write).

\section{Proposal of Azzouz and Abran (2004)}

The proposal resembles previous works such as Bevo (1999) and Jenner (2001). The main difference of the proposal is to make early indicators of functional size measurement possible. The proposal defines three levels of the size estimation concept. The bottom level describes the detailed functional size measurement as in Table 5. Furthermore, because of the fact that there is no UML equivalence of the layer, this problem has been overcome by requesting information from the user manually. The developed tool used artifacts of the application that is produced with the Rational Unified Process (RUP). The solution mapping of the proposal different from previous works is that a new UML stereotype is defined in order to distinguish a trigger event from a simple message in use-case diagrams (Azzouz and Abran, 2004). 
Table 5: Early and detailed size indicator

\begin{tabular}{|c|c|c|}
\hline Development phase & RUP artifacts used & Unit Convention \\
\hline $\begin{array}{l}\text { Business modeling } \\
\text { Requirement analysis }\end{array}$ & Use-case diagram & Use case function size unit (Ufsu) \\
\hline Analysis / Design & Scenarios & Scenario function size unit (Sfsu) \\
\hline Analysis / Design & Detailed scenarios & Cosmic function size unit (Cfsu) \\
\hline
\end{tabular}

Source: Based on Azzouz (2004)

\section{Proposal of Uemura et al. (1999)}

Uemura et al. (1999) proposed detailed FPA measurement rules for the design specifications which are based on the UML. The proposal is also supported with a tool. It focuses on OO-FPA mapping like previous attempts such as Fetcke et al. (1997). Class diagrams and sequence diagrams represent the input of the measurement process. Object of the sequence diagrams defines boundary of the measurement. The objects with methods that change the state of other objects are mapped to ILF. Others are considered as EIF. There are five different sequence diagram patterns restricted by some common assumptions in order to identify type of the transactional functions. The example of the pattern 5 is depicted in Figure 4 (Uemura et al., 1999).

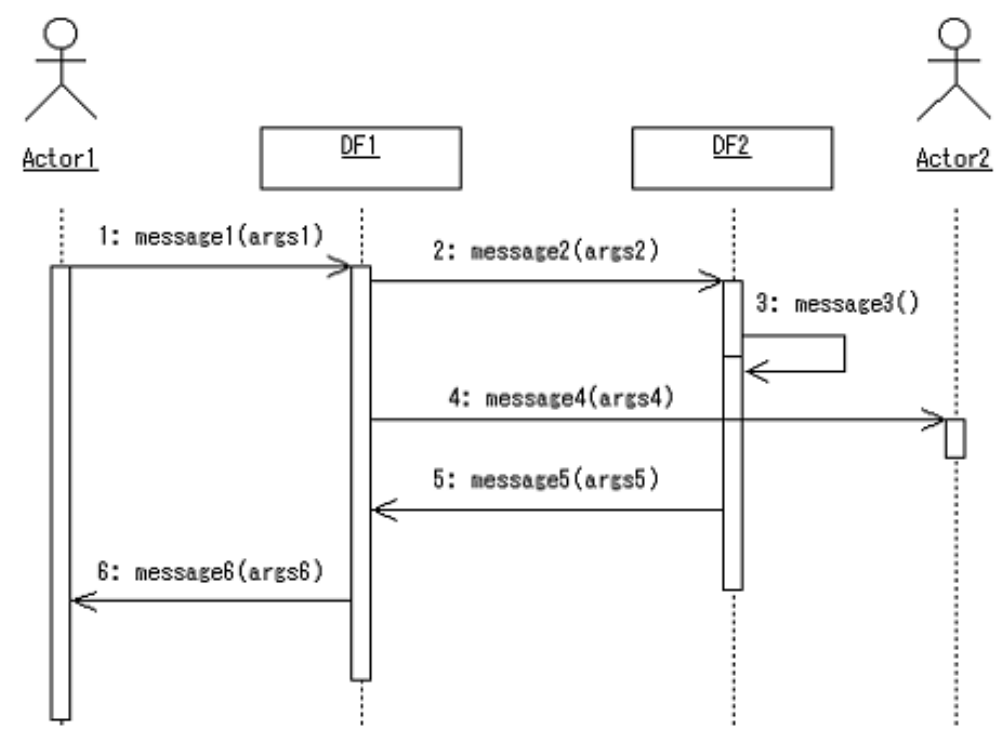

Source: Based on Uemura et al. (1999)

Figure 4: Example of the sequence diagrams pattern 
Although the five patterns is considered enough for determining the transactional function without relying on any additional information, there are some drawbacks. The messages without any argument are not counted and the case of a message being used in different sequence diagrams is not explored in depth (Hericko et al., 2006).

\section{Proposal of Poels (2002)}

The proposal is to provide a set of rules for mapping COSMIC FFP concepts to the Object Oriented (OO) methodology such as MERODE (Snoeck et al., 1999) composed of business model and services model. Poels (2002) supports that event-based 00 enterprise modeling that uses MERODE is suitable for real world and system events. The business model includes class diagrams, an object-event table that describes which type of business events affect which type of business domain objects, and state transition diagrams model. The information system service model provides end-user event transactions to the enterprise model (Poels, 2003). The proposal defines rules of the layered architecture. We can describe functional user of the business layer as objects of the services layer; on the other hand, the functional user of the service layer corresponds to objects of the user interface layer. Functional process of the business model is a set of class methods which are invoked by the occurrence of a type of business event. Functional process of the service model is a non-persistent service object. Data movements are identified according to type of the different class methods (Poels, 2003).

\section{Proposal of Condori-Fernandez et al. (2007)}

Condori-Fernandez et al. (2007) provide an FSM procedure, called RmFFP, which is defined in a systematic way in order to estimate the functional size of a software product from its corresponding requirements specification in the OO-Method approach. As shown in Figure 5, the OO-Method generates software application in an automatic way on different platforms by means of model transformations. OO-Method is comprised of the Requirement Model, which represents the system's functionality, the Conceptual Model, which represents static and dynamic properties of the functional requirements, and the Execution Model, which provide transition from problem space to solution space. 


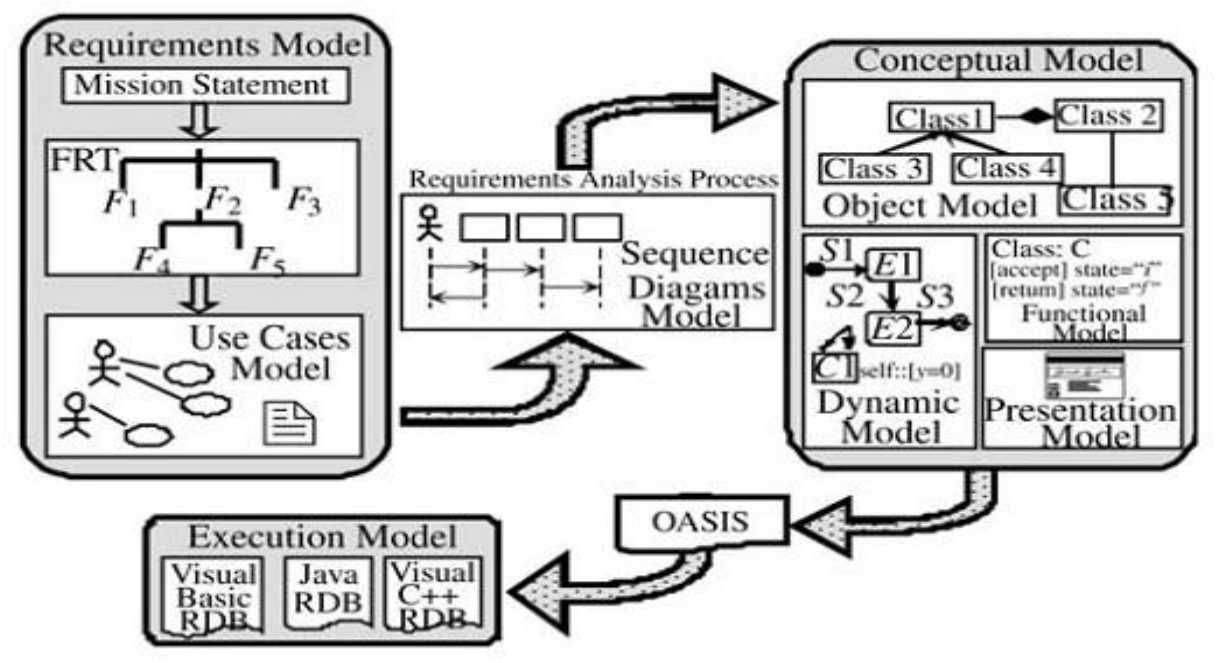

Source: Based on Condori-Fernandez et al. (2007)

Figure 5: The software production models in 00-method

There are three important steps to needed for the application of the measurement procedure. These are software documentation gathering, construction of the software model, and application of the numerical assignment rules. The measurement procedure of the proposals is depicted in Figure 6 (Condori-Fernandez et al. 2007). Use case diagram boundary with actors is accepted as system boundary to be measured. Each primary and secondary use cases that must be leaf node of the function refinement tree are accepted as functional process. Each object of the sequence diagram that includes actor, control class, or entity class is accepted as a data group. The messages of the sequence diagrams are accepted as data movements. 


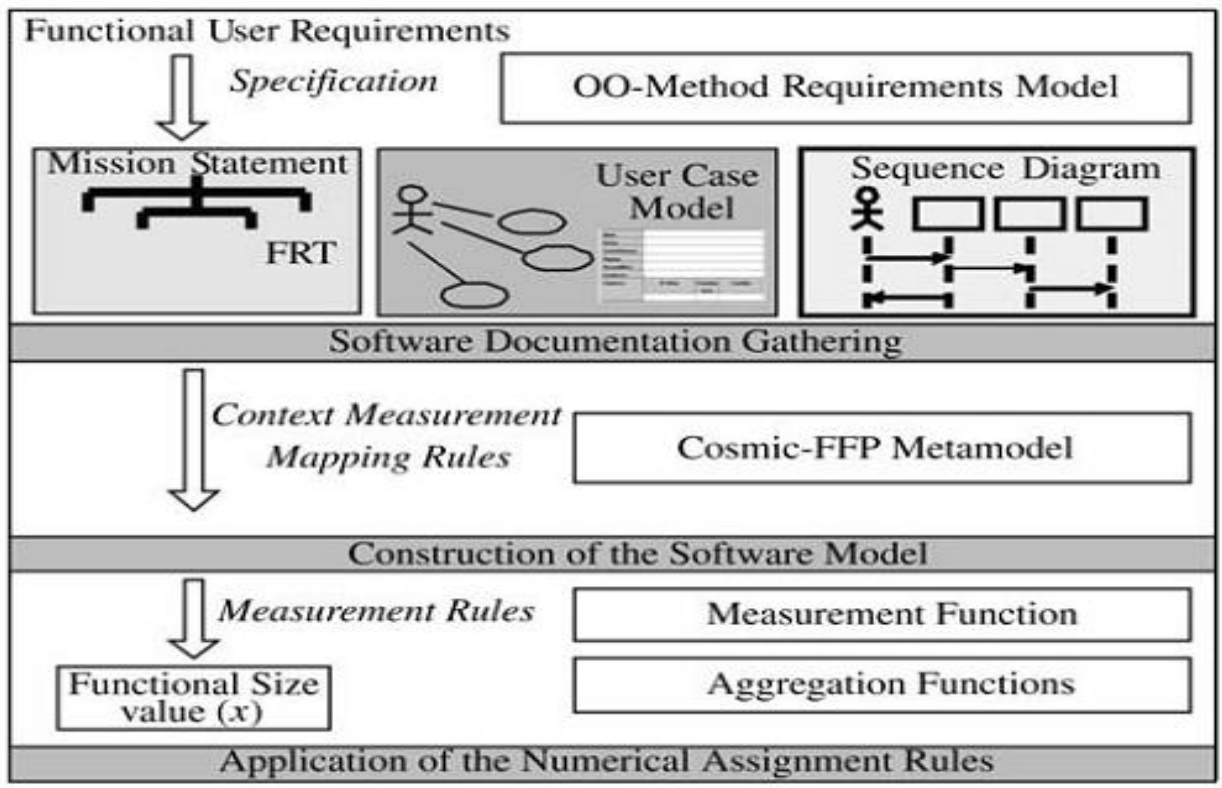

Source: Based on Condori-Fernandez et al. (2007)

Figure 6: Measurement procedure application

\section{Proposal of Levesque et al. (2008)}

The proposal is based on UML specifications such as use case diagrams and sequence diagrams in order to generate functional size of the software product. However, the difference of the proposal from previous work is that Levesque et al. (2008) also considers data manipulation type of the functional process type in order to take into account the complexity of the process.

Comparison of proposals of the functional size automation is given in the Table 6 . The table provides an overview of the reviewed methods in terms of the measurement method they are based on, the input artifacts that they make use of and whether the process has been automated by creating and implementing a script. Table 6 also covers whether the discussed methods have been validated in the relevant studies. 
Table 6: Comparison of proposals of the functional size automation

\begin{tabular}{|c|c|c|c|c|}
\hline Proposal & FSM method & $\begin{array}{l}\text { Input } \\
\text { Artifacts }\end{array}$ & Automated & Validated \\
\hline $\begin{array}{l}\text { Lamma et al. } \\
\text { (1997) }\end{array}$ & $\begin{array}{l}\text { IFPUG FPA v } \\
4.0\end{array}$ & ER-DFD Diagrams & $\begin{array}{l}\text { FUN } \\
\text { (written in } \\
\text { Prolog) }\end{array}$ & No \\
\hline $\begin{array}{l}\text { Bevo et al. } \\
\text { (1999) }\end{array}$ & $\begin{array}{l}\text { COSMIC FFP v. } \\
2.0\end{array}$ & $\begin{array}{l}\text { Use Case, } \\
\text { Scenarios, and } \\
\text { Class Diagrams }\end{array}$ & $\begin{array}{l}\text { Metric } \\
\text { Xpert }\end{array}$ & Yes (case study) \\
\hline Jenner (2001) & $\begin{array}{l}\text { COSMIC FFP v. } \\
2.0\end{array}$ & $\begin{array}{l}\text { Use Case, } \\
\text { Sequences and } \\
\text { Class Diagrams }\end{array}$ & No & Yes (case study) \\
\hline $\begin{array}{l}\text { Diab et al. } \\
\text { (2001) }\end{array}$ & $\begin{array}{l}\text { COSMIC FFP v. } \\
2.2\end{array}$ & $\begin{array}{l}\text { RRRT model } \\
\text { artifacts }\end{array}$ & $\mu \mathrm{CROSE}$ & $\begin{array}{l}\text { Yes (case study, } \\
\text { COSMIC experts) }\end{array}$ \\
\hline $\begin{array}{l}\text { Azzouz and } \\
\text { Abran (2004) }\end{array}$ & $\begin{array}{l}\text { COSMIC FFP v. } \\
2.2\end{array}$ & RUP artifacts & $\begin{array}{l}\text { COSMIC- } \\
\text { RUP }\end{array}$ & Yes (case study) \\
\hline $\begin{array}{l}\text { Uemura et al. } \\
\text { (1999) }\end{array}$ & $\begin{array}{l}\text { IFPUG FPA v } \\
4.0\end{array}$ & $\begin{array}{l}\text { Classes, and } \\
\text { Sequence Diagrams }\end{array}$ & Yes & Yes (Case Study) \\
\hline Poels (2002) & $\begin{array}{l}\text { COSMIC FFP v. } \\
2.1\end{array}$ & $\begin{array}{l}\text { MERODE model } \\
\text { artifacts }\end{array}$ & No & Yes \\
\hline $\begin{array}{l}\text { Condori- } \\
\text { Fernandez }\end{array}$ & $\begin{array}{l}\text { COSMIC FFP v. } \\
2.2\end{array}$ & $\begin{array}{l}\text { OO-Method } \\
\text { requirements } \\
\text { model artifacts }\end{array}$ & $\begin{array}{l}\text { RETO (not } \\
\text { ready) }\end{array}$ & Yes (Case Study) \\
\hline $\begin{array}{l}\text { Levesque et al. } \\
\text { (2008) }\end{array}$ & $\begin{array}{l}\text { COSMIC FFP v. } \\
2.1\end{array}$ & $\begin{array}{l}\text { Use Cases and } \\
\text { Sequence Diagrams }\end{array}$ & No & Yes (Case study) \\
\hline
\end{tabular}

During the literature survey we observed two important improvement opportunities related to early functional size estimation. First, lack of measurement manual of early functional size estimation methods makes the reliability of them directly proportional to the estimator's ability and thus introduces subjectivity to the measurement process. An objective formulation needs to be placed at the core of a proposition for a new functional 
size estimation method, so that formal representation of estimation methods is possible. Such formalization requires a passage from the business realm to the software realm. A potential candidate for such transition is business process model. FSM from the business process models is a new issue and no approach and tool can be found in the literature that automatically generates functional size of the software product from business process models.

Secondly, it has been observed that there is considerable room for improvement by automation of the measurement process. On the application side, such formalization is possible through the automation of the size estimation process. Automating the FSM is a challenging but a rewarding research area as well. Its challenge is mostly due to the difficulties related to the identification and representation of method elements accurately. The rewards include minimizing effort and time spent for measurement, eliminating errors that depend on measurer's ability and increasing repeatability.

In order to perform these improvements, we develop the early functional size estimation method based on measurement manual of COSMIC FSM method in the next chapter. 


\section{CHAPTER 3}

\section{E-COSMIC: FUNCTIONAL SIZE ESTIMATION APPROACH}

Components of the design and implementation of the e-Cosmic method are grouped under three headings and they will be explained in detail respectively.

1. Business Process Model: Business Process Model (BPM) description is used in model extraction that is input to the e-Cosmic FSE method. BPM elements and diagrams were investigated to determine COSMIC FSM method elements and transform them to eCosmic FSE method. The automation requirements of the methodology have also been taken into account during investigation.

2. Method Specification: A method for generating early functional size estimation on business process model using eEPC diagram, function allocation diagram and its elements was developed and formalized based on the COSMIC FSM method principles.

3. Method Implementation: A script that makes use of the specified e-Cosmic FSE method and documents was written in this study. The script calculates functional size based on the e-Cosmic formalism and reports the results.

\subsection{Business Process Models}

EFPA leads to a certain degree of subjectivity due to the fact that "The reliability of the EFPA is directly proportional to the estimator's ability to recognize the components of the 
system as part of one of the proposed classes" (Santillo and Meli, 1998: p7). Hence, early size estimation method developers suggested that the expression of user requirements should be formalized as much as possible. Demirörs and Gencel (2004) claim that business process models may help this formalization. In order to decrease the subjectivity of early size estimation methods, definition of requirements has to be formalized. Since business process models enable the identification of software objects at higher abstraction levels, they are very useful to create a structured estimation process and a standard guideline.

In e-Cosmic, BPM was utilized as an approach for early software functional size estimation. More specifically, eEPC Modeling was used with Architecture of Integrated Information Systems (ARIS) concept for this study, so that roles, inputs, outputs and their relationships could be shown precisely, and functions could be presented with their triggering event.

Essentially there are four types of objects used in the eEPC. These are events, functions, rules and resources (data, entity, organization, and system). An event can trigger a function or a function can produce an event, so combinations of events and functions in a sequence produce eEPCs. Triggering multiple events or functions entails logical operators which are already part of the modeling notation.

Alternative or parallel paths are modeled with logical operators, for example, the AND logical operator is used when all paths are parallel and functions are done simultaneously, the XOR is used to choose only one of alternative paths, the OR logical operator is used when one or more alternative paths can be followed simultaneously. These are some basic examples; however, more complex expressions can be formed according to needs. eEPCs can be hierarchically structured across any number of levels by assigning more detailed eEPCs to every function within an eEPC; thus, it is easy to show sub-processes (Davis and Brabander, 2007).

In addition to business process models, two important concepts are used for the formulation of the proposed e-Cosmic FSE Method. These are Function Tree and Function Allocation Model. We need to define process purpose of the measurement model before 
the definition of function tree. The process purpose is a high level description of the nature and purpose of the system. The goal of this phase is to define what the system will and will not do.

The function tree, on the other hand, depicts the hierarchical decomposition of the business functions as a module representation. It is an organization of external functions and it does not say anything about the internal process of functions. In addition to this, it consists of main business process flow and its leaf nodes are function allocation diagrams that represent the function of desired model with inputs, outputs, and relationships.

Function Allocation Model is used for modeling the functional requirements of system from the view of the user. It represents relationships between function and its environment (Davis and Brabander, 2007). This model is composed of organization, data, systems, knowledge, products and general resources subcomponents. However, this framework covers business processes at a high level. Therefore, we specialize these subcomponents so that they can be related to software size estimation approach. We use the concept of entity to cover data aspects of business process model. The concept of roles refers to organization. Application system is used to account for existing systems of the business process model whereas documents are used to cover general resources. These resource objects, namely entity, roles, application system and document, are allocated to functions in the Function Allocation Diagram (FAD) in the eEPC.

We design FAD based on "CRUDL" to describe whether a process creates, reads, updates, lists or deletes a data object. Object connection to the function is based on these simple relationships depicted in Table 7. FAD is summarized in Figure 7. Functions and some of its relationships are depicted.

Table 7: Data Object Relationship Types

\begin{tabular}{lll}
\hline Connection Direction & Relationship & Base operation \\
\hline Input connection (from & Is input for & Reads \\
data object to function) & & \\
\hline
\end{tabular}


Table 7 ( continued)

\begin{tabular}{lll}
\hline & Reads & Reads \\
& Uses & Updates, Lists \\
\hline & Views & Lists \\
\hline $\begin{array}{l}\text { Output connection (from } \\
\text { function to data object) }\end{array}$ & Has output of & Creates \\
\cline { 2 - 3 } & Changes & \\
& Deletes & Updates, Lists \\
& Views & Deletes \\
\hline & Archives & Lists \\
\hline
\end{tabular}

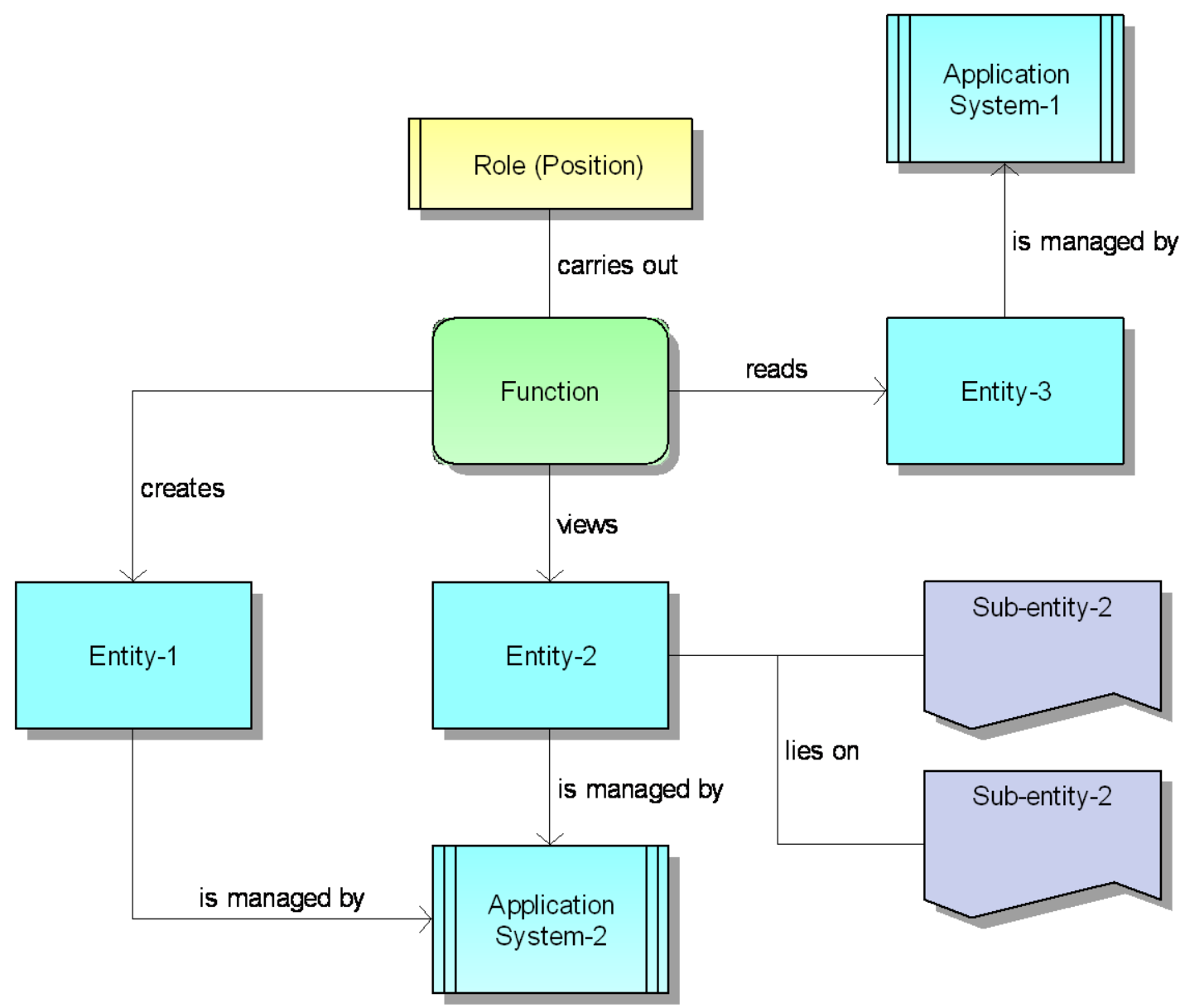

Figure 7: Instance of the function allocation diagram 
Function of the FAD represents base functional components of the proposed method. Each relationship type represents a connection type such as creates, reads and views between a function and an entity. In addition, each entity has to be associated with an application system. Role represents user perspective of the model. For instance, we can interpret part of this diagram as "role views Entity-2 on Application System-2". In addition, Entity-2 is composed of two sub-entities.

\subsection{The Measurement Procedure}

The aim of this measurement procedure is to represent mapping rules between business process model elements and COSMIC FSM method in order to construct e-Cosmic FSE method and its automation principles. Functional requirements are specified by means of business process flow for a product that is intended to support that business process.

\section{Step 1. Identification of the Software Boundary}

Software size varies in terms of identification of the software boundary, since the total size of software aggregated from separately measured software components is more than the size of measurement of whole software. The measurement of the software component but not the whole software system adds an entry-exit pair to the size of software during the interaction with other part of the software components. In addition to this, it is important to identify the users of the system. A role in the business process model or eEPC measurement model approach can be a person who is the user of the application or an external application and device. As a result, user concept of e-Cosmic FSE method is related to roles of eEPC measurement model. We have designed measurement procedure for eCosmic FSE method as follow;

- We should accept each role of eEPC measurement model as a user of the system.

- The border between roles of processes and the set of process flow diagrams can be accepted as the boundary of the system to be measured.

\section{Step 2. Identification of Functional Processes}

The main advantage of the business process modeling based on eEPC is event triggering dependency. Each function in the eEPC model has to be initiated by at least an event sent 
by an actor or by the occurrence of a temporal event. Therefore, each function of the eEPC measurement model is identified as a functional process of e-Cosmic FSE method. The important part here is the level of granularity. We assume that each function that is identified as a functional process has to go down at FAD level, namely, this function does not include any business process flow assignment. COSMIC FSM method defines each functional process to be constituted of at least two data movements (Entry-eXit or EntryWrite), which has to be taken into account for definition of each functional process.

- We should accept each function of eEPC without any assignment as a functional process of e-Cosmic FSE method. It is mandatory to have a FAD diagram for each function involved measurement procedure.

\section{Step 3. Identification of Object of Interest and Data Groups}

The concept of data group is related to the object of interest. Moreover, COSMIC FSM method has not claimed definition of data group attributes as a mandatory phase for size estimation. However, the attributes of an entity can be accepted as attributes that must represent the smallest piece of information. Thus, entities which are specified in the FAD are identified as data groups because they represent a set of attributes of persistent objects. The roles are also candidate for entity so that they have a set of attributes. As a result, we have to add two new mapping rules related to the identification of data groups.

- We should accept each entity in the FADs as a data group.

- We should accept each role that participates in a FAD as a data group

\section{Step 4. Identification of Data Movements}

COSMIC FSM method is based on data movements that are Entry, Read, Write, and eXit. Data movements are identified in the relationship types represented in the function allocation diagrams. First of all, we have to consider output relationship types. Create, view, and list are basic output relationship types. As shown in Table 8 and Table 9, the appropriate set of data movement types are assigned to each output relationship types. The basic relationship types that are labeled with the above stereotype define data movement types in Table 8. 
Table 8: Data movements of output relationship types

\begin{tabular}{ll}
\hline $\begin{array}{l}\text { Output relationship type } \\
\text { (stereotype) }\end{array}$ & Data movement types \\
\hline Creates & 1 Entry, 1 Write \\
Views & 1 Entry, 1 Read, 1 eXit \\
Lists & 1 Entry, 1 Read, 1 eXit \\
Changes & 1 Entry, 1 Read, 1 eXit, 1 Write \\
Deletes & 1 Entry, 1 Write \\
\hline Archives & 1 Entry, 1 Write \\
Updates & 1 Entry, 1 Write \\
\hline
\end{tabular}

Table 9: Data movements of input relationship types

\begin{tabular}{ll}
\hline $\begin{array}{l}\text { Input relationship type } \\
\text { (stereotype) }\end{array}$ & Data movement types \\
\hline Reads & 1 Read \\
Views & 1 Entry, 1 Read, 1 eXit \\
Uses & 1 Entry, 1 Read, 1 eXit, 1 write \\
\hline
\end{tabular}

When an entity used according to these data movements includes attributes of different sub-entities, it is necessary to identify additionally each data movement for each sub-entity. The difference between list and view relationship types is that list relationship type is used for retrieving all instances of an entity in order to allow further selections whereas view relationship type is used for retrieving details of an entity. All confirmation and error messages within the scope of the function have to be accepted as only one eXit data movement.

\subsubsection{Functional Size Calculation Algorithm}

The purpose of this phase is to represent how the measurement procedure proposed in the previous subsection can be applied to the project consisting of business process model and to produce a quantitative value that shows the functional size of the software product. We 
can apply that measurement procedure to the business processes either automatically or manually. Furthermore, a script was developed to estimate software size from the business process model automatically.

In order to define the size of the software product, firstly requirements of the software product presented as business process models has to be transformed to the functional user requirements. However, extracting the e-Cosmic FSE method elements from the functional user requirements is not only time consuming but also error prone work. Instead, elements of the e-Cosmic FSE method developed according to the COSMIC FSM method compatible with the business process model results in effective and correct deliverables than previously discussed approaches. The requirements in the business process model are detailed system-level requirements. The main measurement procedure of the e-Cosmic FSE method is depicted in Figure 8. 


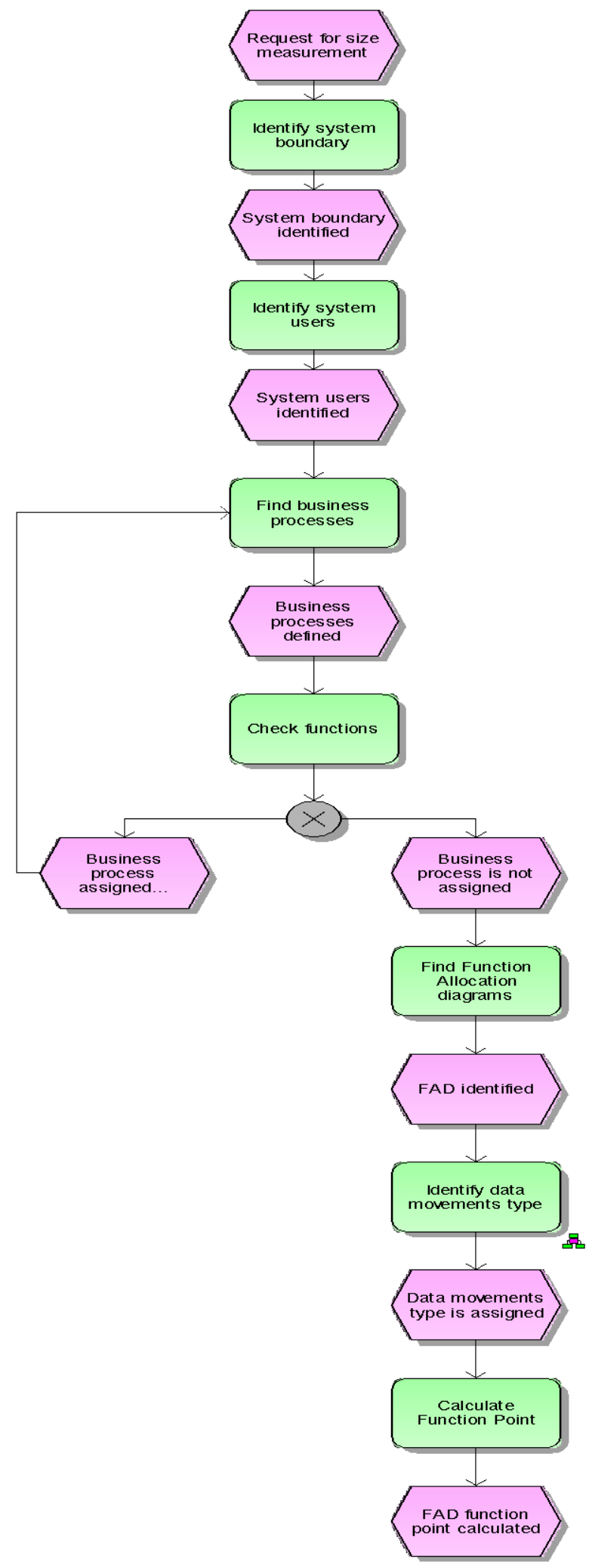

Figure 8: The main procedure of the e-Cosmic FSE method 
The detail of the Identify Data Movement Type step is depicted in Figure 9.

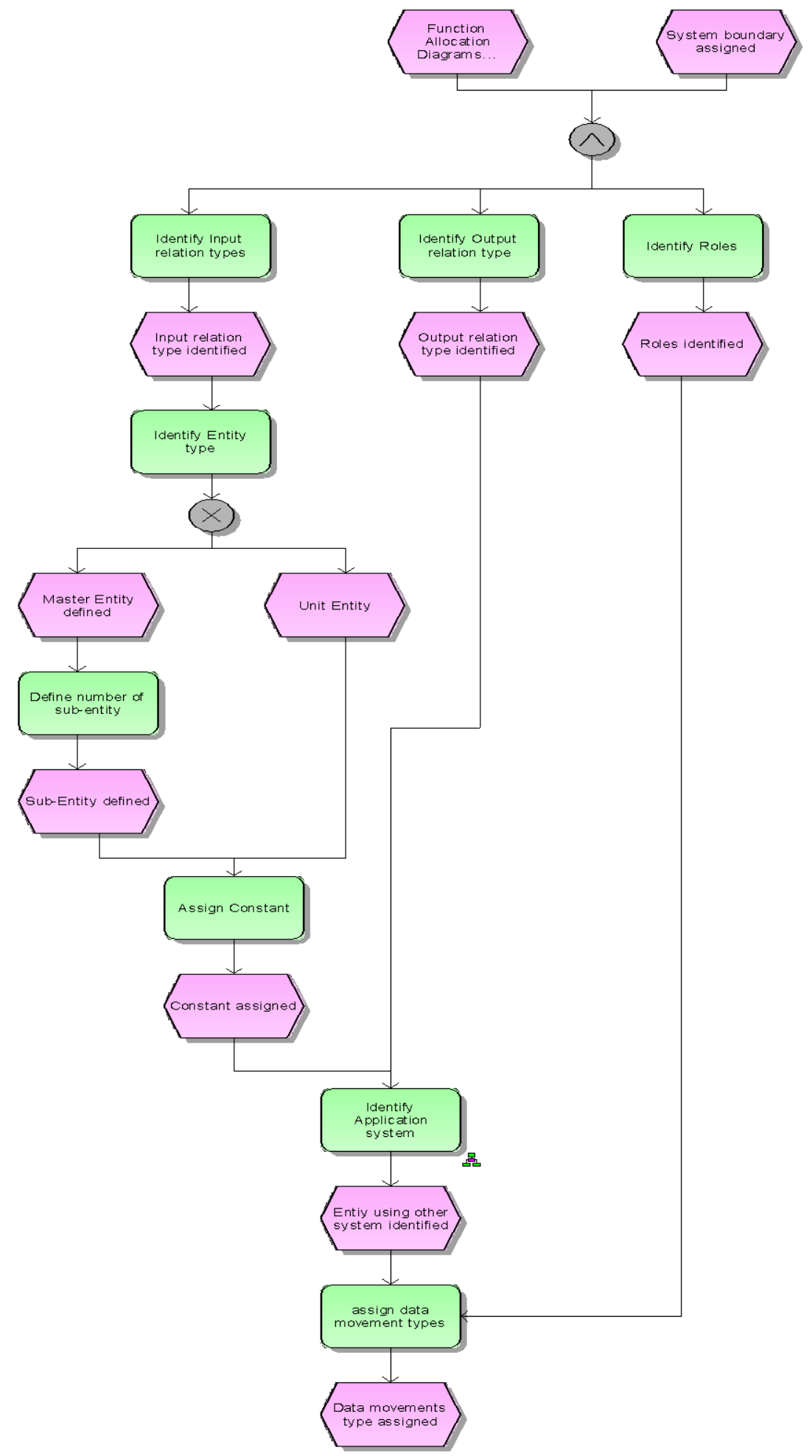

Figure 9: The detail of the Identify Data Movement Type Step 
The detail of the Identify Application System step is depicted in Figure 10.

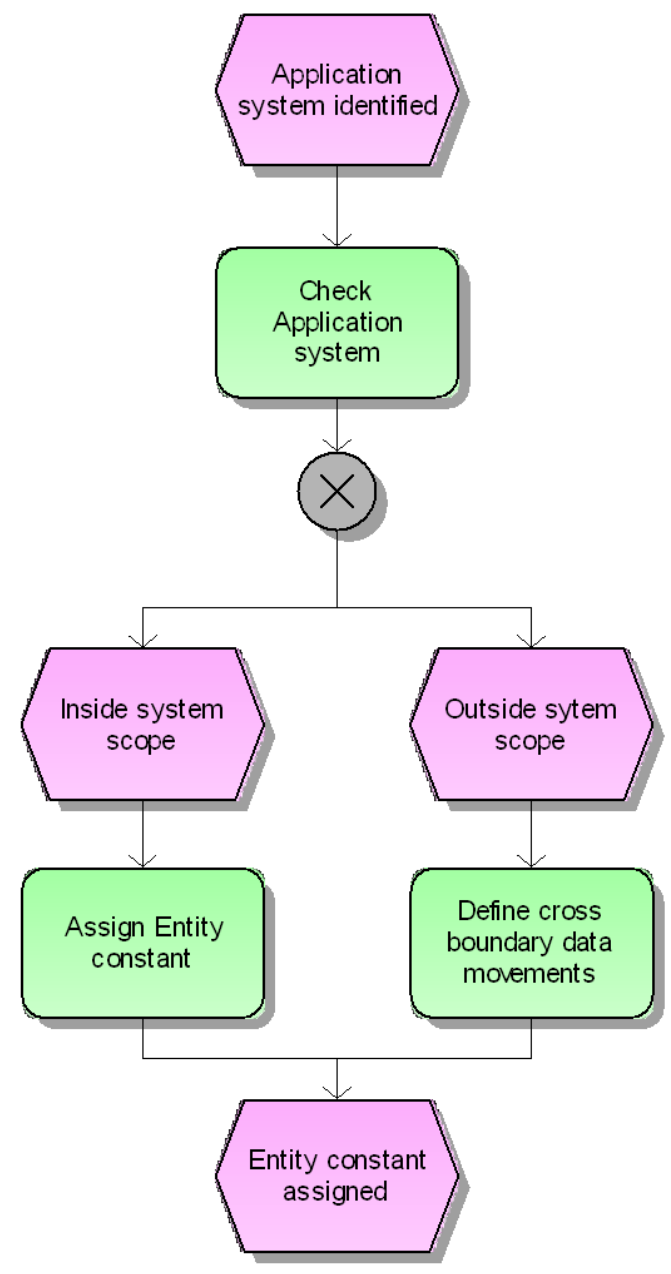

Figure 10: The detail of the Identify Application System step

According to algorithm defined in Figure 8, Figure 9 and Figure 10, firstly software boundary has to be identified as either a whole database that business process model is based on for structure or a module that is a part of database. As a result of this definition, interactions between users and system are easily defined. Then, business processes generating the modules are identified as a starting point of the function definition. The most important part of the function definition is to determine it without any business process assignment. Functions without any business process assignment are named as base functions from this point. 
Base function is figured as FAD in order to determine input, output, relationship types, roles and application systems. Input and output relationship types definition is the most important part of measurement in terms of assignment of data movements

Application system type definition help the determination of the boundary and application systems that are placed outside the software measurement scope also connect some entities. The interaction of those type entities with measured system requires entry-exit pair of data movements. Entities are also separated into two parts; master entity and unit entity. This separation not only affects software size but makes the proposed model more suitable to the COSMIC FSM method with respect to identification of objects of interest as well. Since Master Entity consists of more than one sub-entity, we have to add set of data movements as many as the quantity of sub-entities to the function point of function allocation diagram.

Input and output relationship definition determines each entity behavior since each entity is assigned a set of data movements in terms of relationship types. The assignment of a set of data movements is explicitly identified in previous subsection.

The functional size of a FAD is equal to the sum of all data movements defined in the same FAD. The size of whole system is found by aggregation of functional size of functional allocation diagrams.

\subsection{Method Implementation}

Business process model is developed in ARIS tool environment; therefore, same environment also is used for automating the functional size of the software product. The tool has been developed by IDS Scheer AG to support consultants and companies in creating, analyzing, and evaluating company processes in terms of business process (Scheer, 2001). Each object of the ARIS tool has lots of attributes that consist of common and objects specific properties such as Name, Identifier, and Description. The ARIS toolset enables users to write their own scripts or edit written scripts through a script editor. 
The e-Cosmic script was developed using the ARIS Scripting language which is based on the JavaScript programming language. ARIS Script is a scripting language of ARIS Tool. The core functionality of the e-Cosmic script reports functional size of the software product from business process model. In addition, functional size generation can be filtered according to the groups of the database in order to report partial size of the software.

The execution of the script starts from taking necessary information such as language, database, group, output format and model for the script and controls them. Firstly, database or group selection is completed according to desired functional size measurement approach. And then all groups selected before is searched and sorted by group hierarchy. When these processes are completed, function allocation diagrams are constructed and its functions are identified. Since each function is composed of roles, entities and application systems, counting procedure starts from identifying each of them. All these processes are executed according to the algorithm described in the previous section.

ARIS tool scripting language is composed of various predefined classes and methods. The script is not only composed of sub programs but uses these predefined classes and methods as well. The summary of ARIS tool classes and methods are described in the following subsections (ARIS tool, 2009).

\subsubsection{Description of Classes}

The classes described below are the defined classes of the ARIS Tool Set which are used in the tool. In addition, only common classes used in the script are mentioned below.

1. Context object: The object is a basic class of ARIS tool used to define language and output format.

getSelectedLanguage ( ) : Returns the selected database language

getSelectedFile ( ) : Returns the name of the output file. If several output files have been created, this is the name of the file displayed after running the report.

getSelectedFormat ( ) : Returns the selected output format 
2. ArisData Object : The ARIS start object is registered as the "ArisData" object in each script. It provides database-dependent methods and objects, e.g. the selection data for user (selected groups, models, objects) in the script.

getSelectedFilters ( ) : Returns the list of selected method filters (in context) as a list of MethodFilter objects.

getSelectedDatabases ( ) : Returns the list of selected databases (in context) as a list of Database objects. In the current version only one database can be selected. The list contains only the database that is also returned by ActiveDatabase.

getSelectedGroups ( ): Returns all selected groups. Navigation and inquiries are carried out using the ARIS object model.

sort ( Object[] aObjects, int kriterium1, int localeID ) : Sorts the transferred array containing items of the "Item" class (objects, models etc.) based on the specified sorting criteria.

\section{Database Object}

Find ( int SearchKind ): General database search. Return all items in the database that correspond to the specified search criteria.

\section{Group Object}

ModelListFilter ( int modelTypeNum ) : Returns a list of all models in the group with the specified model type.

\section{Model Object}

ObjOcclistFilter ( int value ) : Returns the object occurrences in the model which meet the specified criteria as a list of object occurrences

\section{ObjOcc Object}

ObjDef ( ) : Returns the object definition as ObjDef .

CxnOcclist ( ) : Returns all relationship occurrences attached to the object occurrence.

7. CxnOcc Object: The object represents a relationship occurrence.

CxnDef ( ) : Returns the relationship definition.

ActiveType_( ) : Returns the active name of the relationship. 
SourceObjOcc ( ) : Returns the occurrence of the source object.

TargetObjOcc ( ) : Returns the occurrence of the target object.

\section{ObjDef Object}

ActiveType_( ) : Returns the active name of the relationship.

9. Item Object: This class contains the common methods of all attribute-bearing items and is also the basic class of all specialized items (object, model, etc.)

Name (int): Returns the name of the item in the specified language as a string.

10. Output Object: The object is an Output object for the ARIS report and outputting documents in RTF, HTML, XLS, PDF and Text (UTF-8) formats.

OutputLn (String $p_{-} s T$ Text, String $p_{-}$Font, int $p_{-}$iFontSize, int $p_{-}$FontColor, int p_BkColor, int p_Format, int p_ilndent): Output of a text in report with line break. 


\section{CHAPTER 4}

\section{CASE STUDY}

This chapter presents case studies performed to validate e-Cosmic Functional size estimation method.

\subsection{Overview}

We performed case studies in order to analyze functional size measurement potential of business process models and validate measurement results.

E-Cosmic FSE method requires business process model as input artifacts to apply its measurement procedure. We have applied the proposed method to a continuing project. We explore the applicability of business process models for functional size measurement and developing an approach for doing this during the first case study. The second and third case studies are performed for comparison and method validation.

\subsection{Case Study Design}

We planned three case studies. The goal of the first case study was to explore applicability of the proposed method. Hence, use cases of the first case study were created in order to apply COSMIC FSM method for finding size of the first software product. When e-Cosmic FSE method was applied to the business process model manually to quantify software size of the first product, we also examined possible deviations from the size obtained by 
applying COSMIC FSM. Because of these concerns the first case study was not used for validation purposes.

Second case study was conducted with a wider view of the applicability of the method. Although both cases are in the information system domain, they reflect different views on software products. The second and third cases are more complex data-driven functions than the first case study. In addition, second and third case studies also contain measurement result of other early estimation method in order to compare their results to the results of the proposed estimation method. Third case study was performed after the script was applied to the whole project. According to the algorithm presented at the previous chapter, script was executed to take whole project as an input. When whole project functional size was determined, we decided to implement the third case study in order to complete the validation purpose. All of the selected case products are in the MIS domain.

The details of the case studies are described in this chapter. The main aim of the experimental study was to validate the e-Cosmic FSE procedure. Other aims were to determine possible improvement opportunities and measure the effectiveness of the method and discover if there were other benefits of the method. The aim of this thesis study is not only to create an early functional size estimation method and support it with measurement manual but to automate this measurement procedure as well.

The research questions of the case studies are

- What are the business process model's elements that can be utilized for measuring functional size?

- What are the problems and difficulties of the current early functional size estimation based methods and improvement opportunities?

- Is there a significant deviation between the proposed early size estimation method and COSMIC FSM method results? 
- How much does the proposed early size estimation method improve software size estimation with respect to the available methods in the literature?

The implementation plan of the case studies is depicted in Table 10.

Table 10: Implementation plan of Case Studies

\begin{tabular}{|c|c|}
\hline No & Activity to be performed \\
\hline & Case study 1 (Part 1 ) \\
\hline 1 & Identification of a coherent set of business processes. \\
\hline 2 & $\begin{array}{l}\text { Software requirement specifications of the first set of business processes are } \\
\text { constituted. }\end{array}$ \\
\hline 3 & $\begin{array}{l}\text { The size of the first set of business processes is counted based on defined } \\
\text { requirements by using COSMIC FSM v3.0. }\end{array}$ \\
\hline 4 & $\begin{array}{l}\text { e-Cosmic FSE developed in the context of this thesis study is applied to count } \\
\text { the size of the first set of business processes. }\end{array}$ \\
\hline \multirow[t]{2}{*}{5} & e-Cosmic FSE v1.0 is constituted. \\
\hline & Case Study 2 (Part 2) \\
\hline 6 & Identification of a coherent set of business processes. \\
\hline 7 & $\begin{array}{l}\text { Software requirement specifications of the second set of business processes } \\
\text { are constituted. }\end{array}$ \\
\hline 8 & $\begin{array}{l}\text { The size of the second set of business processes is counted based on defined } \\
\text { requirements by using COSMIC FSM v3.0. }\end{array}$ \\
\hline 9 & $\begin{array}{l}\text { e-Cosmic FSE is applied to count the size of the second set of business } \\
\text { processes. }\end{array}$ \\
\hline \multirow[t]{2}{*}{10} & $\begin{array}{l}\text { Other early estimation method (Early and Quick COSMIC FFP) is applied to the } \\
\text { first and second set of business processes in order to compare results. }\end{array}$ \\
\hline & Case Study 3 (Part 3) \\
\hline 11 & Identification of a coherent set of business processes. \\
\hline 12 & $\begin{array}{l}\text { Software requirement specifications of the third set of business processes are } \\
\text { constituted. }\end{array}$ \\
\hline
\end{tabular}


Table 10 ( continued)

13 The size of the third set of business processes is counted based on defined requirements by using COSMIC FSM v3.0.

14 Other early estimation method (Early and Quick COSMIC FFP) is applied to the third set of business processes in order to compare results.

15 Script is completed by using ARIS tool scripting language and applied all set of business processes.

16 Functional size of the third set of business processes is calculated by executing script.

17 Results are compared.

\subsubsection{Case Study 1: Constructing e-Cosmic FSE method}

The goal of the first case study is exploration of the similar concepts in business process models and functional size measurement method and establishment of a draft early size estimation method. Specifically, the first case attempts to address the research question of identifying the business process model elements that can be utilized for measuring functional size and point out the problems and difficulties of the current early functional size estimation based methods. We also explored any improvement opportunities during the early functional size estimation by means of comparing the proposed method results to the COSMIC FSM results.

Business processes of the "Extending Independent Auditor Pool" (EIAP) of Development Agency were chosen as the business process set to be applied. We selected EIAP since it displays an adequate level of complexity. That is, EIAP has different process levels which provide a rich environment to test the proposed method. But it is not too complex so that it is possible to identify improvement opportunities for e-Cosmic.

EIAP business processes were modeled with eEPC by using ARIS tool. We determined that eEPC business process models is suitable for identifying COSMIC base functional components, we also utilized a resource allocation mapping concept for each function 
involved in the size measurement scope of the eEPC diagrams. We also decide whether function might be a part of the software product at this phase. If we develop a FAD for a function, we associate this function as a part of the software product.

We determined the business processes of the first case study that is part of the Development Agency Process Modelling project in order to count size of the software product. To calculate the size of the software product we need to determine the requirements of the same product. COSMIC FSM is designed to measure software product size from its FURs. Uses cases are used to extract FURs, and then each FUR is decomposed to functional processes.

We extracted the functional user requirements as input to the COSMIC FSM method for software size estimation. To provide the integrity among the size measurement results, the functional sizes of the case products measured were filled in a preformatted Excel table which consisted of "functional process name", "data movement type", and "data group description". Then this size of the software product was verified by a certificated COSMIC FSM measurer. Use case models are also verified by an object-oriented analysis/design expert. In addition, all of the sizes of the case products were measured by using COSMIC v3.0 by the author of this thesis. The use case model and COSMIC FSM method results are given in Appendix B.

Once the size of the software products was measured, we started constructing e-Cosmic FSE procedure on the business process models of the first case study in order to estimate functional size manually.

The instance of business process model in the EIAP considered being a part of the software product is given in Appendix A. The business process model includes 9 functions initiated by events. Each function also includes 1 FAD to represent input-output relationships of resources. However, the level of granularity of one function of this business process is not the same as with the other functions; so a new business process is assigned to this function. This new business process also includes 6 functions initiated by events. Totally, two distinct 
diagrams consisting of 14 functions were created to model existing business processes of organization unit by using the eEPC notation. The reason why these business processes are selected is to include opportunities for possible improvements. Firstly, measurement procedure is applied to the business processes, and then refinements have been identified through this measurement procedure.

In order to find any shortcomings during the method procedure, every step was monitored. The summary of the measurement results of the first case study using the e-Cosmic FSE method is given in Table 11 in the case study results part.

\subsubsection{Case Study 2: Comparing Estimation Methods}

Second case study is more related to the performance of the proposed e-Cosmic method. This case study addresses two research questions. The first question is whether there is a significant deviation between proposed early size estimation method and software size obtained by applying COSMIC FSM. Second question we ask is by how much software size estimation is improved by e-Cosmic method with respect to the available methods in the literature. In order to answer these questions, results from e-Cosmic FSE method are compared with another early estimation method; Early and Quick COSMIC FFP.

The second case study is performed on "Perform Project Payments" (PPP) business process models of Development Agency. This case study is deliberately chosen as a bigger boundary than first case study. The first case study included 14 functions whereas the second case study involves three distinct diagrams consisting of 29 functions to model existing business processes of organization unit by using the eEPC notation. This increase creates higher complexity and presents a better ground for comparing the performances of e-Cosmic to Early and Quick COSMIC FFP. The second case study consists of the PPP activities. Business processes of this case study contain arrangement of payment system for each project. The conduct of each payment phase such as prepayment, interim payment and final payment is handled. In addition, project contractor related issues are also solved in this phase. 
The conduct of the second case study is the same as the first case study. Firstly, we determined requirement specifications. Uses cases were created to extract FURs so as to apply COSMIC FSM method procedure and then proposed early size estimation method was applied to find functional size of the software product. The case study result is explained in the case study results part.

The implementation of Early and Quick COSMIC FFP is that this method makes use of both analogical and analytical classification of functionalities (Meli and Santillo, 1999). The key factor defining detail level of the method is determined as function of eEPC model. Each function of the eEPC model is classified in terms of their complexity and a set of FP values (min, avg, max) based on analytical tables are assigned to each object. The sum of values generates estimate of software product size.

\subsubsection{Case Study 3: Implementation of e-Cosmic FSE method}

The aim of the third case study is quite similar to the purpose of conducting the second case study. Same research questions are addressed. Firstly, we investigate the existence of deviation between proposed early size estimation method and software size obtained by applying COSMIC FSM. Secondly, we try to assess the software size estimation improvements brought about by the proposed early size estimation method. This second research question is tackled by comparisons to the available methods in the literature. Even though the research questions of the two case studies are identical, the third case study involves automation of the proposed e-Cosmic method.

When we decided to select the third and last case study, we have attempted finishing the script which executes the automation procedure of the e-Cosmic FSE method. After finishing the script of the e-Cosmic FSE method in the ARIS tool environment, we determined business processes of the third case study as input for script to estimate functional size of the last case study. We also determined requirements. Uses cases were created to extract FURs so as to apply COSMIC FSM method procedure. 
In order to answer the formulated research questions, the written script is executed and obtained results are compared with the result of the software products obtained by applying COSMIC FSM. Thus, with the last case study, we validate not only the result of the measurement procedure but the result of the automation procedure as well. The last case study is of nearly the same boundary size as the second case study.

The last case study consists of the "Problem Management" (PM) activities. Early warning, infraction of rules and contract termination works are conducted in the last case study. The third case study involves three distinct diagrams consisting of 29 functions to model existing business processes of organization unit. This case, as in the second case study, provides a complex environment to compare results of different methods. It is also complex enough to challenge an automated software size estimation method. The last case study result is explained in the case study results part.

\subsection{General Discussions on the Case Studies and the Results}

The first case study is deliberately more detailed than other case studies for we want to increase the comprehensibility of the steps of the e-Cosmic measurement procedure and then the case study results and our inferences based on these results are explained in the following parts. The estimation results of the "Extending Independent Auditor Pool" business processes are given in Table 11.

Table 11: Summary of e-Cosmic FP of the "Extending Independent Auditor Pool"

\begin{tabular}{|c|c|c|c|c|c|}
\hline Functional Process & $\begin{array}{l}\# \text { of } \\
\text { Entry }\end{array}$ & $\begin{array}{l}\# \text { of } \\
\text { Exit }\end{array}$ & $\begin{array}{l}\# \text { of } \\
\text { Read }\end{array}$ & $\begin{array}{l}\# \quad \text { of } \\
\text { Write }\end{array}$ & $\begin{array}{l}\text { CFP } \\
\text { count }\end{array}$ \\
\hline Create IA selection criteria & 3 & 3 & 3 & 1 & 10 \\
\hline Create IA advertisement text & 3 & 1 & 1 & 1 & 6 \\
\hline Create IA reference documents & 1 & 0 & 0 & 1 & 2 \\
\hline $\begin{array}{l}\text { Plan IA advertisement time, } \\
\text { advertisement tool, and application }\end{array}$ & 1 & 0 & 0 & 1 & 2 \\
\hline
\end{tabular}


Table 11 (Continued)

\begin{tabular}{|c|c|c|c|c|c|}
\hline Send outputs to approve & 2 & 1 & 1 & 1 & 5 \\
\hline Review IA outputs & 1 & 5 & 5 & 1 & 12 \\
\hline Update IA outputs & 5 & 5 & 5 & 4 & 19 \\
\hline Prepare for advertisement tools & 1 & 0 & 1 & 1 & 3 \\
\hline Announce acquisition advertisement & 1 & 4 & 4 & 0 & 9 \\
\hline Receive IA applications & 2 & 0 & 1 & 1 & 4 \\
\hline Determine selection committee & 2 & 1 & 1 & 1 & 5 \\
\hline Select IA applications & 5 & 2 & 2 & 4 & 13 \\
\hline Approve selected IA & 3 & 2 & 2 & 2 & 9 \\
\hline Save selected IA & 2 & 0 & 1 & 1 & 4 \\
\hline List IA selection criteria & 1 & 1 & 1 & 0 & 3 \\
\hline Update IA selection criteria & 1 & 0 & 0 & 1 & 2 \\
\hline Delete IA selection criteria & 1 & 0 & 0 & 1 & 2 \\
\hline List IA advertisement text & 1 & 1 & 1 & 0 & 3 \\
\hline Update IA advertisement text & 1 & 0 & 0 & 1 & 2 \\
\hline Delete IA advertisement text & 1 & 0 & 0 & 1 & 2 \\
\hline List IA reference documents & 1 & 1 & 1 & 0 & 3 \\
\hline Update IA reference documents & 1 & 0 & 0 & 1 & 2 \\
\hline Delete reference documents & 1 & 0 & 0 & 1 & 2 \\
\hline List IA acquisition plan & 1 & 1 & 1 & 0 & 3 \\
\hline Update IA acquisition plan & 1 & 0 & 0 & 1 & 2 \\
\hline Delete IA acquisition plan & 1 & 0 & 0 & 1 & 2 \\
\hline \multicolumn{5}{|c|}{ TOTAL CFP } & 131 \\
\hline
\end{tabular}

The results obtained from the COSMIC FSM method are represented for each functional process of the business processes and data movements are also represented for each function in Table 12. 
Table 12: Cosmic Function Point of "Extending Independent Auditor Pool" by means of COSMIC

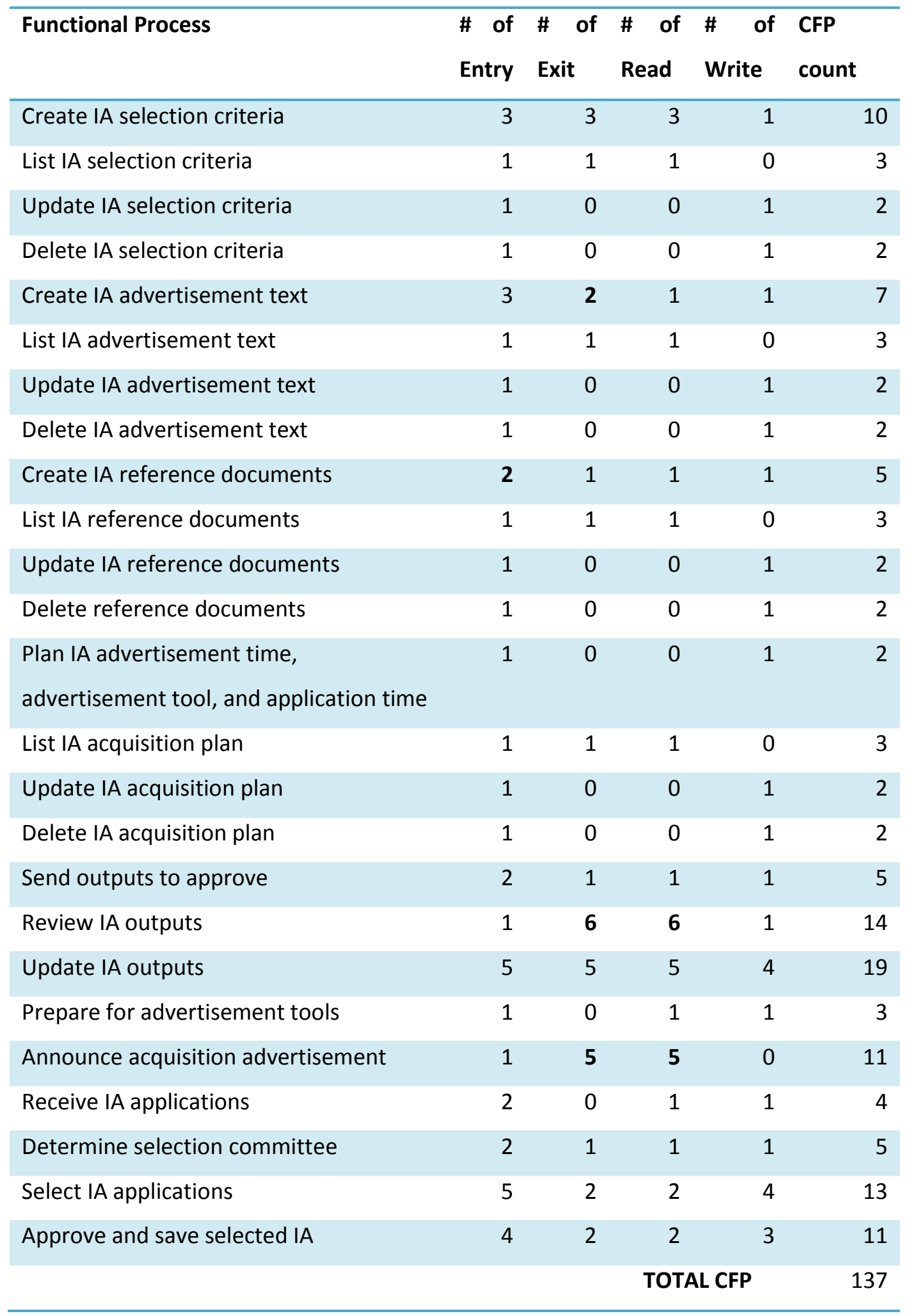


When the COSMIC functional processes which are extracted from the requirement specifications depicted in Table 12 are compared with the functional processes of the eCosmic FSE procedure in Table 11, we find out few differences. Also, the quantity of functions of the use case model is one function less than the quantity of proposed measurement procedure functions. The difference resulted from the combination of two functions as one function in COSMIC FSM approach. Since identification of use cases is left to the measurer, such deviations may occur in the COSMIC FSM method, legitimizing the concern for subjectivity. Still, software product size estimation from the use case brought about few refinement potentials on the proposed measurement procedure. These improvements are listed below.

- User interactions have to be taken into account. For this purpose we revised the view relationship type. The differences of view and read relationship types are not only quantity of data movements but their measurement view point differs as well since read does not take into account any user interaction. On the other hand view relationship type is identified to reflect user interactions better.

- For each function, we added one triggering entry in order to consider user role effects.

- We also clarify effect of sub-entity type; if an entity lies on sub-entities, we have to increase quantity of data movements depending on quantity of sub-entities.

The other improvement is to find that create relationship requires list, delete and update relationships for the size estimation. When we need to use create relationships, an entity is created, and so each created entity would be updated and deleted by users. To perform this operation, we also require list relationship type for each entity. Update, delete and list data movements pattern is given in Table 13 below.

In Table 13, data movements that are allowed in the relationship type are marked with an * sign.

Table 13: Update, delete, and list pattern for an entity

\begin{tabular}{|c|c|c|c|c|}
\hline Relationships type & Entry & Exit & Read & Write \\
\hline Update & $*$ & & & $*$ \\
\hline
\end{tabular}


Table 13 (Continued)

\begin{tabular}{llll} 
Delete & $*$ & & $*$ \\
List & $*$ & $*$ & $*$ \\
\hline
\end{tabular}

The business processes of the software products was calculated by means of this pattern for four functions that require create relationship. Therefore, software product size would be $131 \mathrm{FP}$. This increase is inevitable for a business process model because of the addition of the size of list, delete and update operations.

When the results obtained from e-Cosmic which is 131 CFP and COSMIC FSM (Table 12) which is 137 are compared, it is found that the difference between the results is 6 CFP. The software product size estimation from the business process model for this particular example resulted in 5\% lower result than the COSMIC FSM value that was produced by using the use case model. The functional processes where differences from Table 11 occurred are represented with bold numbers in Table 12.

The reason for such a difference is that the measurement by using use case model considers triggering event for each function that starts without any triggering event. However, this difference is not based on COSMIC measurement procedure as a special rule. This variance purely resulted from measurer's interpretations of the FUR. The other differences also reflect measurer's interpretations. For instance, when a function completes its task, the last purpose of such a function either saves results or shows results to the user. However, if we want to do both operations for some functions, these operations also increase data movements and contribute to the size of software product.

We continue explaining relationship types and measurement procedure by giving two function allocation diagrams in order to clarify steps. The first function of the EIAP business process, "create IA selection criteria", depicts relationships and sub-entity situations (Figure $11)$. 


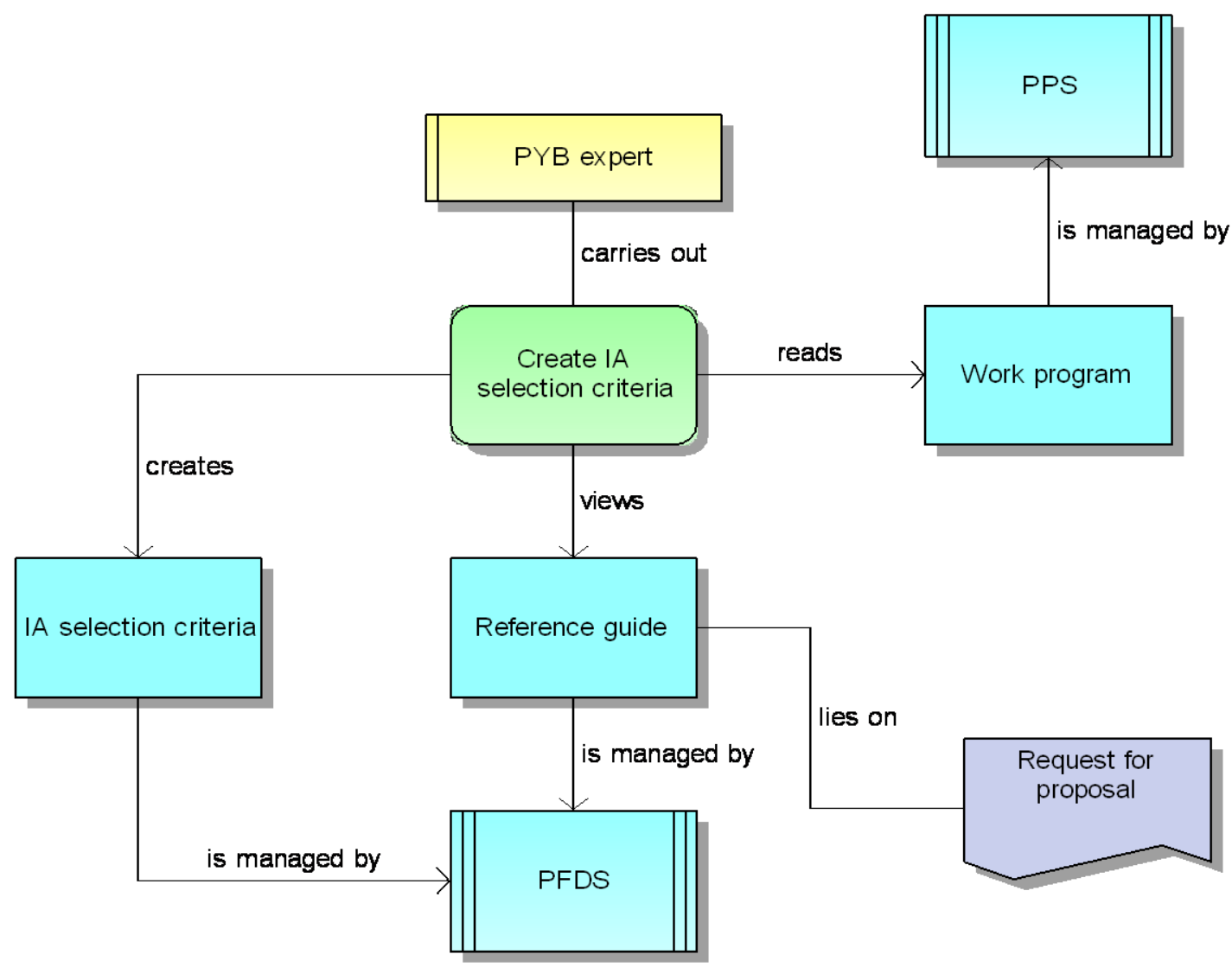

Figure 11: Function allocation diagram of "create IA selection criteria"

In Table 14, data movements that are allowed in the relationship type are marked with an * sign.

Table 14: Mapping of relationship types into data movements for "create IA selection criteria"

\begin{tabular}{lcccc}
\hline Relationships Type & Entry & Exit & Read & Write \\
\hline Reads & $*$ & $*$ & $*$ & \\
Views & $*$ & & $*$ & $*$ \\
Creates & $*$ & & \\
\hline
\end{tabular}

The function depicted in Figure 11 includes two application systems; however, both of them are in the same measurement scope. Therefore, we do not have to take into account the application system so that there are not any effects to increase the data movements. 
The other important part is sub-entity type. "Reference guide" entity includes request for proposal sub-entity. So according to proposed measurement procedure, we have to add data movements of "request for proposal" for each set of data movements of "reference guide". We can also see roles relationship types as "carries out". The second function of the EIAP business process, "update IA outputs", is given in the detail in Figure 12 to depict measurement procedure steps.

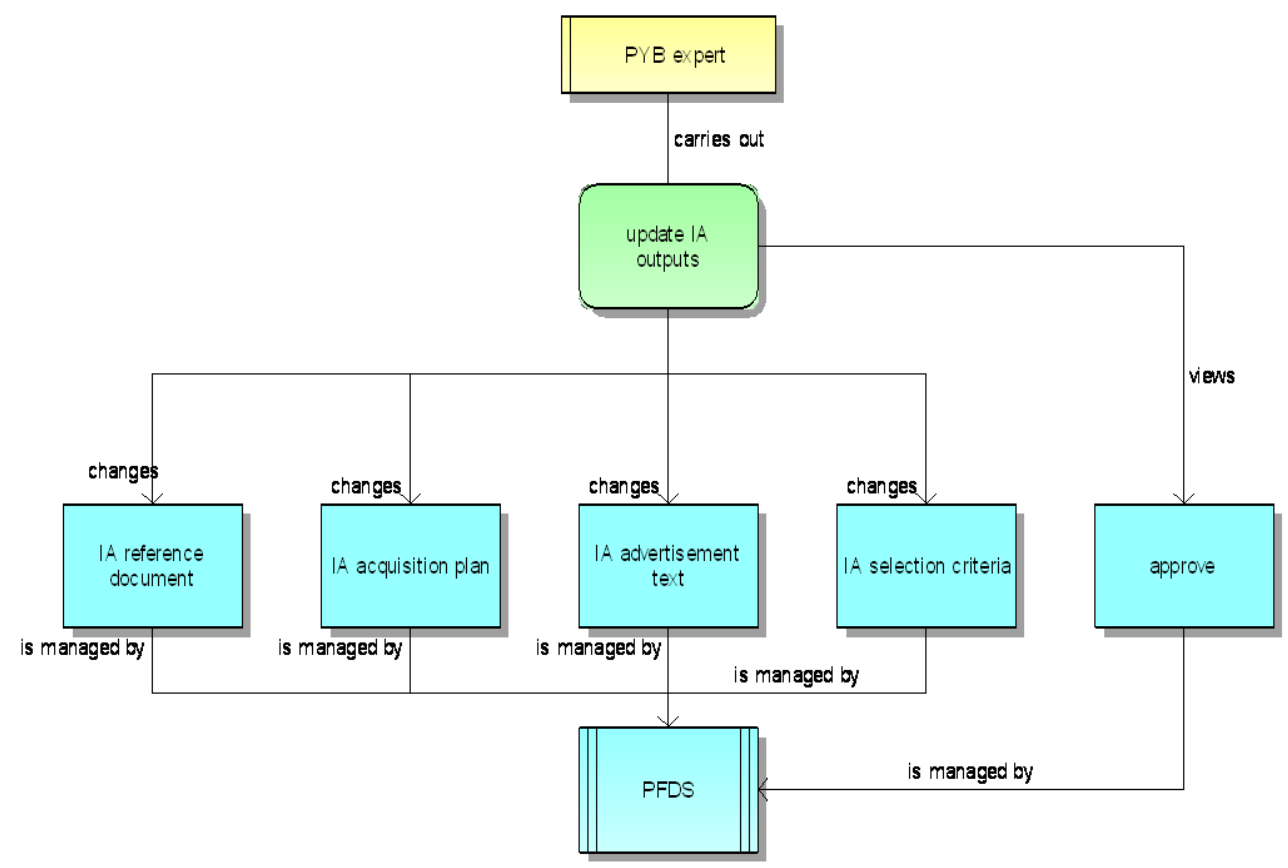

Figure 12: Function allocation diagram of "update IA outputs"

Table 15: Mapping of relationship types into data movements for "update IA outputs"

\begin{tabular}{lllll}
\hline Relationships & Entry & Exit & Read & Write \\
\hline Views & $*$ & $*$ & $*$ & \\
Changes & $*$ & $*$ & $*$ & $*$ \\
\hline
\end{tabular}

The function in Figure 12 explains an important part of measurement procedure in terms of the change relationship types. Change relationship type includes both update and listbefore update data movements. Also, view relationship type differs from read with respect 
to quantity of data movements. User interactions are classified as list, list-before update, and list-before create. View relationships type covers all of them.

Functional sizes are computed by the e-Cosmic method for each functional process separately. FP count values of each software product are given in Table 16. This table provides data for a statistical analysis.

Table 16: CFP count of each functional process for software products by e-Cosmic

\begin{tabular}{|c|c|c|c|}
\hline $\begin{array}{l}\text { Functional } \\
\text { Process }\end{array}$ & $\begin{array}{c}\text { CS-1 } \\
\text { (CFP Count) }\end{array}$ & $\begin{array}{c}\text { CS-2 } \\
\text { (CFP Count) }\end{array}$ & $\begin{array}{c}\text { CS-3 } \\
\text { (CFP Count) }\end{array}$ \\
\hline$f p-1$ & 10 & 25 & 6 \\
\hline$f p-2$ & 7 & 7 & 15 \\
\hline$f p-3$ & 6 & 12 & 7 \\
\hline$f p-4$ & 7 & 7 & 7 \\
\hline$f p-5$ & 2 & 4 & 6 \\
\hline$f p-6$ & 7 & 6 & 8 \\
\hline$f p-7$ & 2 & 6 & 7 \\
\hline$f p-8$ & 7 & 7 & 8 \\
\hline$f p-9$ & 5 & 7 & 15 \\
\hline$f p-10$ & 12 & 6 & 6 \\
\hline$f p-11$ & 19 & 22 & 7 \\
\hline$f p-12$ & 3 & 14 & 7 \\
\hline$f p-13$ & 9 & 9 & 15 \\
\hline$f p-14$ & 4 & 7 & 7 \\
\hline$f p-15$ & 5 & 16 & 3 \\
\hline$f p-16$ & 13 & 7 & 6 \\
\hline$f p-17$ & 9 & 12 & 3 \\
\hline$f p-18$ & 4 & 7 & 10 \\
\hline fp-19 & - & 6 & 7 \\
\hline$f p-20$ & - & 24 & 7 \\
\hline
\end{tabular}


Table 16 ( continued)

\begin{tabular}{|cccc|}
$\mathrm{fp-21}$ & - & 7 & 3 \\
\hline $\mathrm{fp}-22$ & - & 8 & 3 \\
\hline $\mathrm{fp}-23$ & - & 24 & 5 \\
\hline $\mathrm{fp}-24$ & - & 7 & 15 \\
\hline $\mathrm{fp}-25$ & - & 12 & 3 \\
\hline $\mathrm{fp}-26$ & - & 7 & 7 \\
\hline $\mathrm{fp}-27$ & - & 9 & 10 \\
\hline $\mathrm{fp}-28$ & - & 6 & 8 \\
\hline $\mathrm{fp}-29$ & - & 7 & 3 \\
\hline
\end{tabular}

Based on the data available in Table 16 and Table 17 summarizes the mean and standard deviation of the functional processes of three software products. Software product in case Study 2 has the highest mean and standard deviation values with respect to functional size of each functional process. Comparing columns 1 and 2 in Table 17 shows that the average functional size of the functional processes and the related standard deviation increase with the number of functional processes of the software product. However, comparing columns 1 and 3 shows that while the average functional size of the functional processes may remain unchanged, standard deviation may even decrease as the number of functional processes of the software product increases. Finally, columns 2 and 3 taken together imply that the average functional size of the functional processes and the related standard deviation may be independent of the number of functional processes of the software product.

Table 17: Statistical analysis of the case studies with respect to size of the functional processes

\begin{tabular}{rccc}
\hline & CS-1 & CS-2 & CS-3 \\
\hline Sum (CFP) & 131 & 298 & 214 \\
Mean & 7.28 & 10.28 & 7.38 \\
Std & 4.30 & 6.11 & 3.67 \\
\hline
\end{tabular}


Table 18 shows that estimation deviations of the e-Cosmic FSE method from the COSMIC FSM method for software products are $4.38 \%, 6.29 \%$ and $5.31 \%$ respectively. As shown in Figure 13, the deviation of results obtained from e-Cosmic FSE method with respect to COSMIC FSM method are seen to increase with the increase in the functional size of the software products. Also, estimation deviations are acceptable in order to validate the eCosmic FSE method according to the other early functional size estimation ranges. There are not any differences between quantity of functional sizes of the e-Cosmic FSE and COSMIC FSM. We have not observed any effect of the quantity of the functional processes on the functional sizes clearly.

Table 18: Deviation between total functional sizes of the software products with respect to the methods

\begin{tabular}{rccc}
\hline & CS-1 & CS-2 & CS-3 \\
\hline E-Cosmic FSE (Total CFP) & 131 & 298 & 214 \\
\hline COSMIC FSM (Total CFP) & 137 & 318 & 226 \\
\hline Estimation deviation(CFP) & 6 & 20 & 12 \\
\% Estimation deviation & 4.38 & 6.29 & 5.31 \\
\# of Functional Process & 18 & 29 & 29 \\
\hline
\end{tabular}

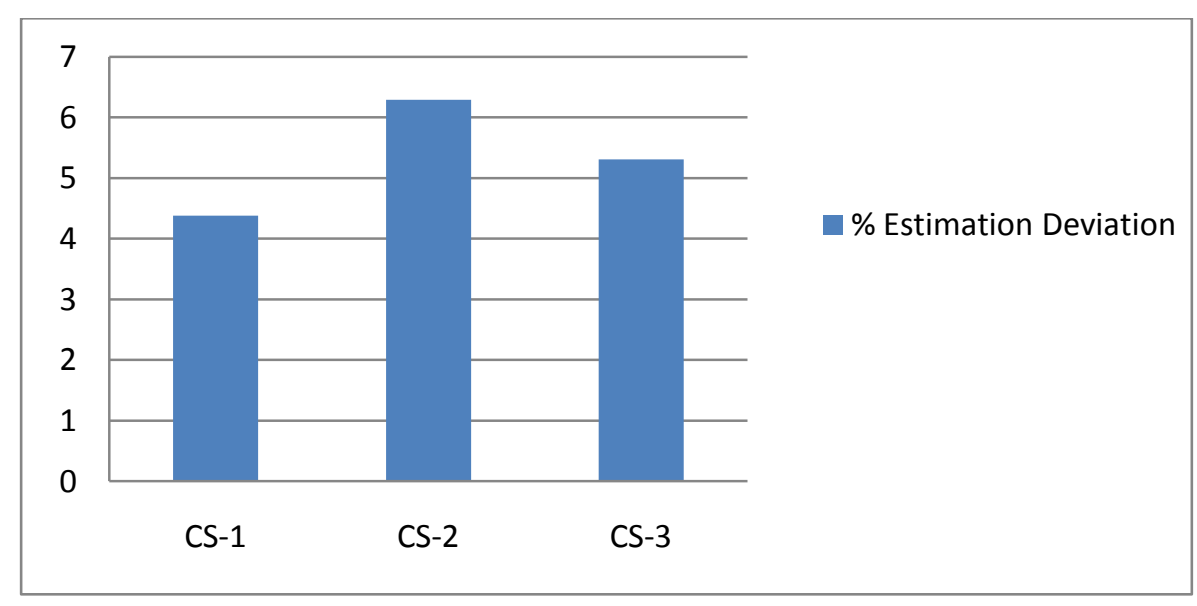

Figure 13: Estimation deviations between total functional sizes of the software products with respect to the methods

Early and Quick COSMIC FFP method, another functional size estimation method, was applied to the three case studies according to the values based on analytical tables as 
standard by Early and Quick COSMIC method's developers. Results are given in Table 19. We have used values published by Conte et al. (2004).

Table 19: Implementation of Early and Quick COSMIC FFP method on the case studies

\begin{tabular}{lccc}
\hline & Min. CFP & Most likely CFP & Max. CFP \\
\hline CS-1 & 123.00 & 190.80 & 241.00 \\
CS-2 & 223.00 & 345.30 & 438.00 \\
CS-3 & 178.00 & 275.70 & 348.00 \\
\hline
\end{tabular}

Table 20: Size estimates by Early and Quick COSMIC FFP and the deviations with respect to COSMIC FSM.

\begin{tabular}{lccc}
\hline & Min. & Most likely & Max. \\
\hline CS-1 & -10.22 & 39.27 & 75.91 \\
CS-2 & -29.87 & 8.58 & 37.74 \\
CS-3 & -21.24 & 21.68 & 53.98 \\
\hline
\end{tabular}

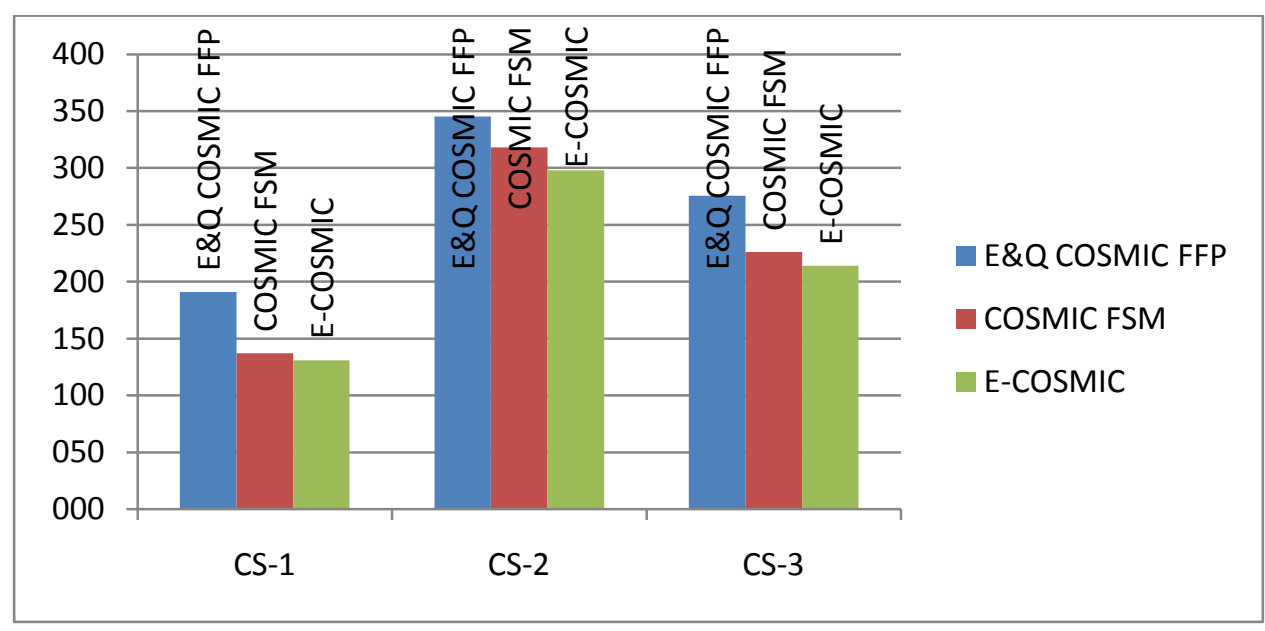

Figure 14: Comparison of the functional size of the software products with respect to the employed methods

As shown in Figure 14, if we compare the functional size of e-Cosmic FSE method with results of COSMIC FSM method, we can observe that functional sizes are underestimated 
by using e-Cosmic FSE. However, the differences are not significant if one considers $10 \%$ as a deviation benchmark for significance, a benchmark proposed by Santillo and Meli (1998). In addition, the functional sizes are overestimated by using the E\&Q COSMIC FFP 2.0 (Conte et al., 2004). We used average values of the E\&Q COSMIC FFP 2.0 method for comparison in Table 20. The results of the E\&Q COSMIC FFP 2.0 are not so reliable according to the results of the other two methods. On the other hand, upon comparing e-Cosmic and E\&Q COSMIC FFP 2.0 values with COSMIC FSM values, we can see that e-Cosmic values are closer to COSMIC FSM values than E\&Q COSMIC FFP 2.0 values.

Effort values of COSMIC FSM and e-Cosmic FSE method are summarized in Table 21. As shown in Table 21, the effort needed to make an e-Cosmic estimation is found to be about $44 \%$ less than the effort to make a measurement with COSMIC FSM for the software products. We can conclude that e-Cosmic FSE method reduces the required effort for measurement.

Table 21: Effort values for COSMIC FSM and e-Cosmic

\begin{tabular}{llccc}
\cline { 3 - 4 } Method & Phase & CS-1 & CS-2 & CS-3 \\
\hline COSMIC FSM & $\begin{array}{l}\text { Requirement Specification } \\
\text { (man-hours) }\end{array}$ & 14 & 10 & 10 \\
& $\begin{array}{l}\text { Size Measurement } \\
\text { (man-hours) }\end{array}$ & 10 & 9 & 9 \\
\hline e-Cosmic & Size Measurement & & & \\
& (man-hours) & 6 & 5 & 5 \\
\hline
\end{tabular}

In summary, compared to a benchmark case of COSMIC FSM method, e-Cosmic performs at least no worse than the E\&Q COSMIC FFP method. e-Cosmic method differs from E\&Q COSMIC FFP method in determination of components to be used in software size measurement. e-Cosmic is based on business process models, a relatively well formulated framework that is less prone to deviations caused by subjectivity. E\&Q COSMIC FFP 
method, however, lacks such a foundation. Therefore, the analysis conducted so far implies non-negligible gains from formalization of software size estimation methods. 


\section{CHAPTER 5}

\section{CONCLUSION AND FUTURE WORK}

This chapter summarizes results, contribution, and significance of this research and suggests future research directions.

\subsection{Conclusion}

In this study, a method of early functional size estimation based on Business Process Models is developed. Business process model artifacts, which are widely used in information system environment, are used as input to e-Cosmic FSE method.

We also developed a software that automates parts of the methodology. In order to construct and verify the applicability of e-Cosmic method, we performed three case studies. COSMIC FSM method, E\&Q COSMIC FFP and e-Cosmic FSE methods were applied during these case studies in order to find the functional size. The improvement opportunities have been observed by comparing the results.

Based on the three case studies conducted we have found out that e-Cosmic FSE method can successfully estimate the size of the software to be developed. Santillo and Meli (1998) suggested $10 \%$ deviation benchmark for significance. Our results have consistently displayed less than $10 \%$ deviation. The estimation deviations vary from $4.38 \%$ to $6.29 \%$ with respect to COSMIC FSM results. These deviations resulted from additionally identified exit data movements in the COSMIC FSM method in order to display function 
results to the users and the list relationships. E-Cosmic FSE method underestimated the software product size.

The estimation deviations of E\&Q COSMIC FFP vary from $8.58 \%$ to $39.27 \%$ with respect to COSMIC FSM results. When we compare estimation deviations of E\&Q COSMIC FFP and eCosmic FSE methods values for each case study, we can see that the estimation deviations of e-Cosmic FSE are significantly smaller than the estimation deviations of the E\&Q COSMIC FFP. Based on these comparisons, we can conclude that e-Cosmic FSE method produced more precise result than the other method in the literature.

In addition, since the reliability of the E\&Q COSMIC FFP is directly proportional to the estimator's ability to "recognize" the components of the system as part of one of the proposed classes, E\&Q COSMIC FFP method entails a large degree of subjectivity. We have largely eliminated the subjectivity by e-Cosmic FSE by precisely defining the counting rules based on the process models. This study showed that business process models can be used for decreasing subjectivity and increasing reliability of the early size estimation technique.

Conventional FSM methods accomplished automation of the measurement procedure based on software model artifacts at a late phase of the software life cycle. We also show that e-Cosmic method provides software size estimation at an early phase of the software life cycle when business process model is available. Business process model artifacts are chosen due to the fact that it is suitable for formalization of the user requirements. They are widely used in information system domain and available at the beginning of the software life cycle.

Another result is that the effort needed to make e-Cosmic FSE is less than the effort to make E\&Q COSMIC FFP and COSMIC FSM. The effort needed to make manual calculation by using COSMIC FSM was 9 man-hours. On the other hand, the effort needed to make estimation based on e-Cosmic FSE was a few man-minutes for the same product. This reduction in man-hours is due to automation of the size estimation process in e-Cosmic FSE. 
The constructed algorithm enabled automation of the size measurement process. The automation, in turn, led to improvements in effort needed for size estimation process.

The automation of the measurement procedure eliminates measurer dependency and manual calculation effort in conventional early functional size estimation methods. This also decreases advanced measurement training needs.

\subsection{Future Work}

E-Cosmic FSE method can be applied to different application domains. The performed case studies were in management information systems. In order to make method more general, we should apply the method to different functional domains such as real-time systems or control strong systems. We also should apply method to more case studies.

This study can be further improved by making use of different notations in business process model and adjusting or modifying the method if necessary in order to widen its applicability.

Given that the e-Cosmic method underestimates the real software size, further research can be conducted on the e-Cosmic method to see if this underestimation is systematic. Then, it may be possible to understand if the underestimation takes place by a constant ratio. Once this constant has been identified, e-Cosmic results can be increased by making use of the identified constant to make the results converge to real software sizes. 


\section{REFERENCES}

Abran, A. (1999). COSMIC FFP 2.0: An Implementation of COSMIC Functional Size Measurement Concepts, FESMA'99, October7, Amsterdam, Holland.

Abran, A., Desharnais, J.-M., Oligny, S., St-Pierre, D. \& Symons, C. (2003). COSMIC FFP Measurement Manual - the COSMIC Implementation Guide for ISO/IEC 19761: January.

Abran, A., Desharnais, J.M., Lesterhuis, A., Londeix, B., Meli, R., Morris, P., Oligny, S., O'Neil, M., Rollo, T., Rule, G., Santillo, L., Symons, C. \& Toivonen, H. (2007). The COSMIC Functional Size Measurement Method Manual, version 3.0. GELOG.

Abrahao, S., and Insfran, E., (2008). A Metamodeling Approach to Estimate Software Size from Requirements Specifications, 34 th Euromicro Conference Software Engineering and Advanced Applications,SEAA.2008.53.

Albrecht, A. (1979). Measuring Application Development Productivity. Proceedings of the Joint SHARE/GUIDE/IBM Application Development Symposium, (pp. 83-92).

Azzouz, S. \& Abran, A. (2004). A proposed measurement role in the Rational Unified Process (RUP) and its implementation with ISO 19761: COSMIC FFP. Proceedings of the Software Measurement European Forum 2004, Rome, Italy.

Boehm, B. (1981). Software Engineering Economics. New Jersey: Prentice Hall.

Condori-Fernández, N., Abrahão, S. \& Pastor, O. (2007). On the Estimation of Software Functional Size from Requirements Specifications. Journal of Computer Science and Technology, 22(3), 358-370.

Conte, M. Iorio, T. Meli, R. \& Santillo, L. (2004). E\&Q: An Early \& Quick Approach to Functional Size Measurement Methods, in Software Measurement European Forum (SMEF), Rome, Italy.

Davis, R. \& Brabander, E. (2007). ARIS Design Platform Getting Started with BPM, London: Springer- Verlag. 
Demirörs, O. \& Gencel, Ç. (2004). A Comparison of Size Estimation Techniques Applied Early in the Life Cycle, European Software Process Improvement Conference (EurSPI 2004), Lecture Notes in Computer Science (LNCS), pp.184-194.

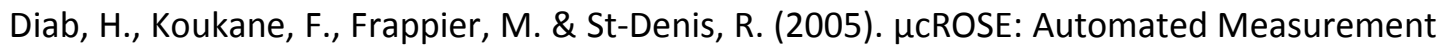
of COSMIC-FFP for Rational Rose Real Time. Information and Software Technology, $47(3), 151-166$.

Fenton, N. E. \& Pfleeger, S. L. (1997). Software Metrics: A Rigorous and Practical Approach, Second Edition. Boston, MA :International Thomson Computer Press.

Fetcke, T. (1999). A generalized structure for function point analysis. Proceedings of International Workshop on Software Measurement (IWSM'99), Mont-Tremblant, Canada, $1-11$.

Fetcke, T., Abran, A. \& Nguyen, T. (1997). Mapping the $0 O$ - Jacobson, Approach into Function Point Analysis, Software. Proceedings of Technology of Object-Oriented Languages and Systems 23. Santa Barbara, CA, USA, 192-202.

Galorath D. D. \& Evans M. W. (2006). Software sizing, estimation, and risk management : when performance is measured performance improves. USA : Auerbach Publications.

Glass, R.L. (2003). Facts and Fallacies of Software Engineering. Boston, MA : Addison Wesley.

Hericko, M., Rozman, I. \& Zivkovic, A. (2006). A formal representation of functional size measurement methods. The journal of Systems and Software, 79(9), 1341-1358.

Hlupic, V. \& Robinson, S., (1998). Business Process Modeling and Analysis Using DiscreteEvent Simulation, Proceedings of the Winter Simulation Conference, 2, (pp. 1363-1369).

ISO/IEC (1998). 14143R1: Information Technology - Software Measurement Functional Size Measurement Part 1: Definition of Concepts.

ISO/IEC (2002). 20968:2002: Software Engineering - Mark II Function Point AnalysisCounting Practices Manual.

ISO/IEC (2003a). 19761:2003: Software Engineering COSMIC FFP: A Functional Size Measurement Method.

ISO/IEC (2003b). 20926:2003: Software Engineering - IFPUG 4.1 Unadjusted FSM MethodCounting Practices Manual.

Jones, C. (2007). Estimating Software Costs : Bringing Realism to Estimating. New York : McGraw-Hill Companies. 
Jones, C. (2008). Applied Software Measurement : Global Analysis of Productivity and Quality. New York : McGraw-Hill.

Lamma, E., Mello, P. \& Riguzzi, F. (2004). A System for Measuring Function Points. Computer journal, 47( 3) , 358-372.

Levesque, G., Bevo, V. \& Cao, D.T. (2008). Estimating software size with UML models. Proceedings of the 2008 C3S2E Conference, Montreal, 81-87.

Marin, B., Giachetti, G. \& Pastor, O. (2008). Measurement of Functional Size in Conceptual Models: A Survey of Measurement Procedures Based on COSMIC , IWSM / MetriKon / Mensura 2008, LNCS, vol 5338/2008, (pp. 170-183).

Meli, R. (1997). Early and Extended Function Point: A New Method for Function Points Estimation, IFPUG-Fall Conference, September 15-19, Scottsdale, Arizona, USA.

Meli, R. \& Santillo L. (1999). Function Point Estimation Methods: A Comparative overview, FESMA 98-The European Software Measurement Conference, October 6-8. , Amsterdam, Holland.

Meli, R., Abran, A., Ho, V.T. \& Oligny, S. (2000). On the Applicability of COSMIC FFP for Measuring Software Throughout Its Life Cycle, Proceedings of the ESCOM-SCOPE 2000, April, Munich, Germany, Shaker Publ., ( pp. 289-297).

Poels, G. (2003). Functional Size Measurement of Multi-Layer Object-Oriented Conceptual Models. Proceedings of the 9th International Object-Oriented Information Systems Conference, Geneva, (pp. 334-345).

Poels, G. (2002). A Functional Size Measurement Method for Event-Based Object-Oriented Enterprise Models. Proceedings of the 4th International Conference on Enterprise Information Systems -ICEIS, Ciudad Real, ( pp. 667-675).

Rask, R. (1991). Algorithms for Counting Unadjusted Function points from Dataflow Diagrams, Research report, University of Joensuu, Finland.

Santillo, L. \& Meli, R. (1998). Early Function Points: some practical experiences of use, ESCOM-ENCRESS 98, May 18, Roma, Italy.

Scheer, A.W. (2001). ARIS Methods, Berlin: Springer.

Symons, C. (2001). Come Back Function Point Analysis (Modernized) - All is Forgiven!), Proceedings of the 4th European Conference on Software Measurement and ICT Control, FESMA-DASMA 2001, Germany,( pp. 413-426).

Uemura, T., Kusumoto, S. \& Inoue, K. (1999). Function Point Measurement Tool for UML Design Specification. Proceedings of the 5th International Software Metrics Symposium, IEEE Metrics, Florida, USA, ( pp. 62-71). 
van den Berg, K.G., Dekkers, T. \& Oudshoorn, R. (2005). Functional Size Measurement applied to UML-based user requirements. Proceedings of the 2nd Software Measurement European Forum (SMEF2005), 16-18 March 2005, Rome, Italy.

Vogelezang, F. (2005). Early estimating using COSMIC-FFP, SMEF'05 Conference proceedings, Rome, 16-18 March. 


\section{APPENDICES}

APPENDIX A: BUSINESS PROCESS MODEL

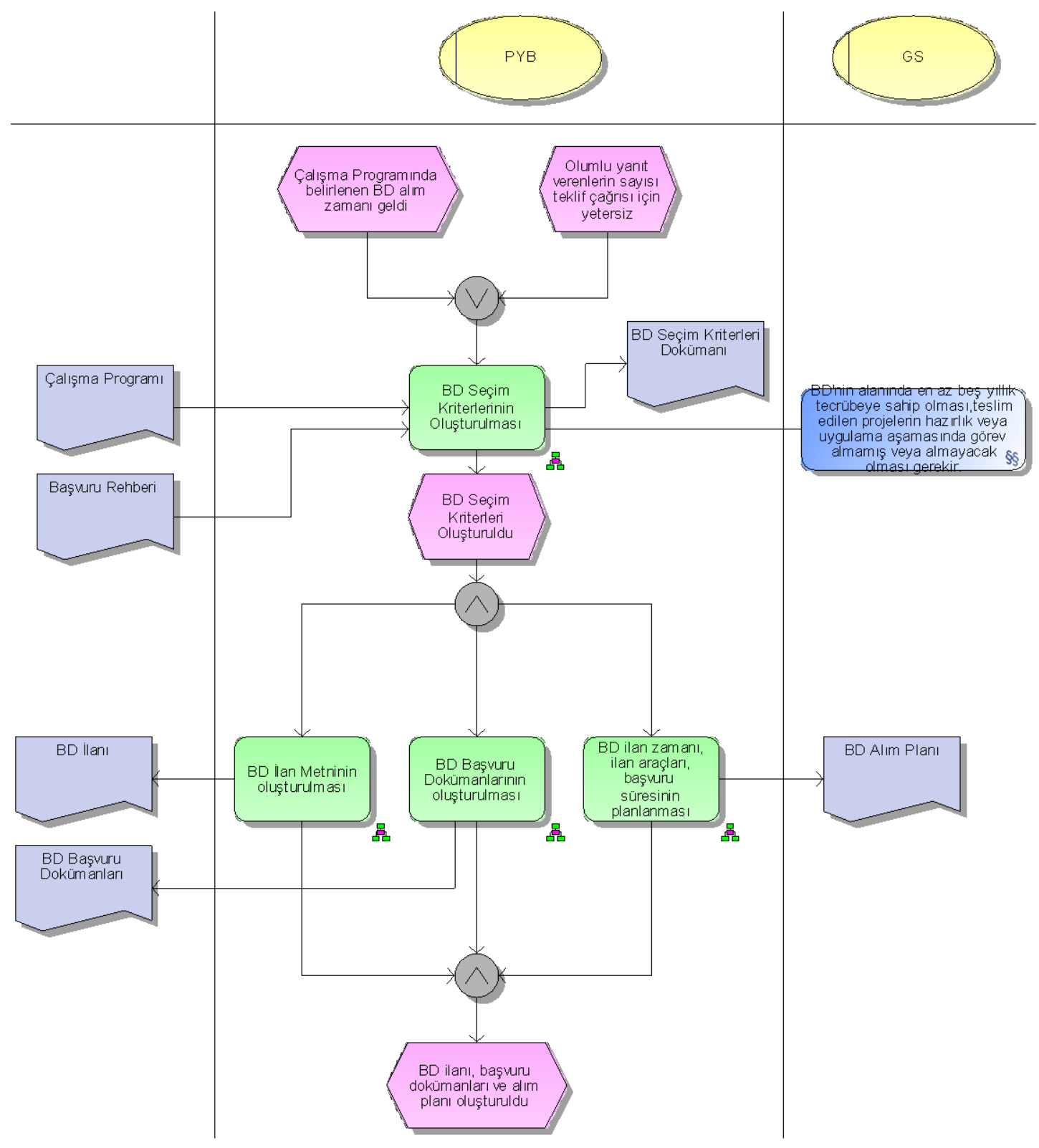




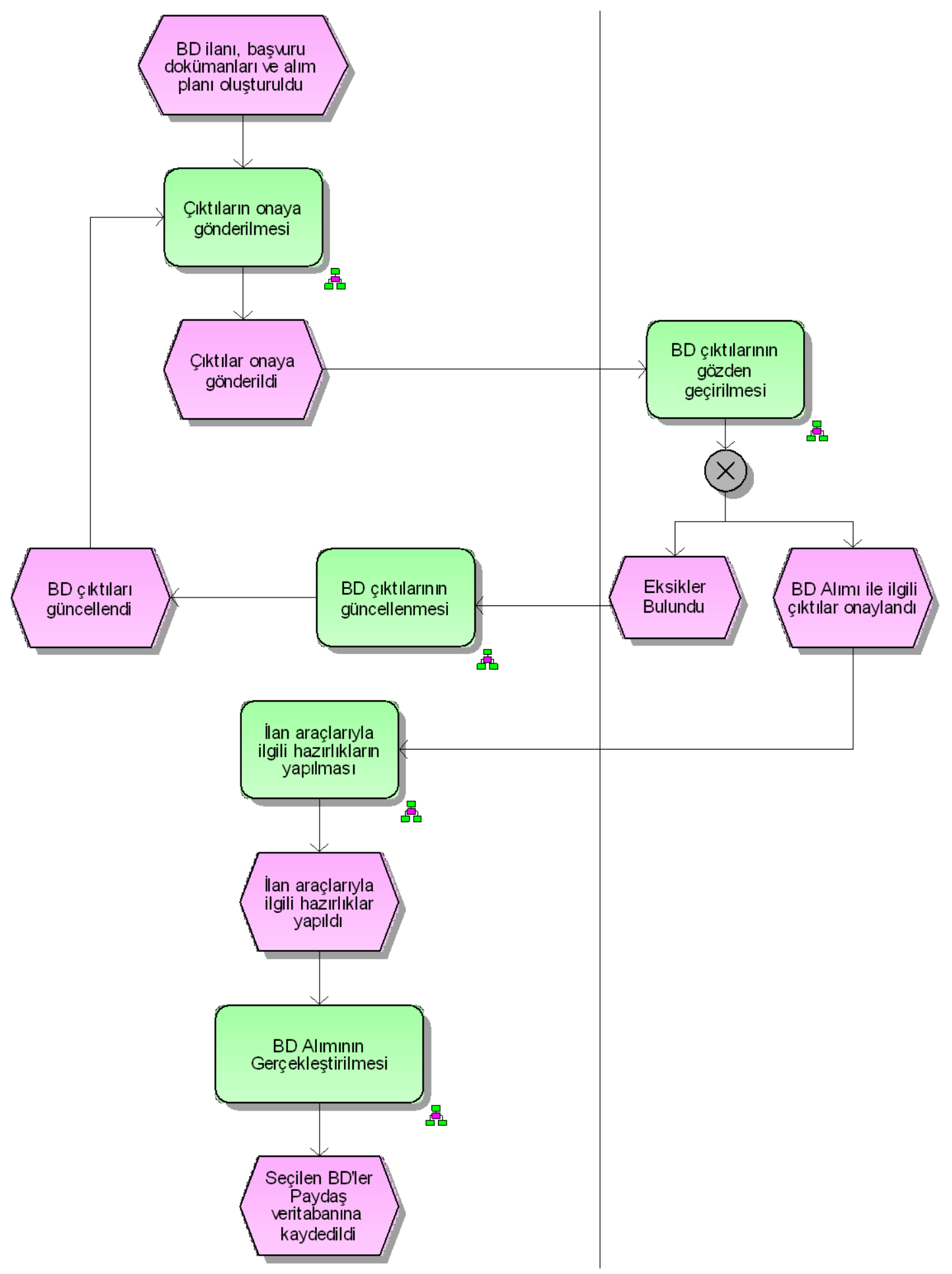

Figure 16 : Business Process Model instance 
APPENDIX B: USE CASE MODEL AND COSMIC FSM

BAĞIMSIZ DEĞERLENDIRICILERIN BELIRLENMESI SÜRECi

\begin{tabular}{|c|c|}
\hline Use Case & \#1: BD seçim kriterlerinin oluşturulması \\
\hline Primary Actor & PYB Uzmanı \\
\hline Stakeholders & PYB Uzmanı \\
\hline Minimal Guarantees & - \\
\hline Success Guarantees & Seçim kriterleri oluşturuldu. \\
\hline Preconditions & - \\
\hline Triggers & Çalışma programında belirlenen BD alım zamanının gelmesi. \\
\hline Main Scenario Success & 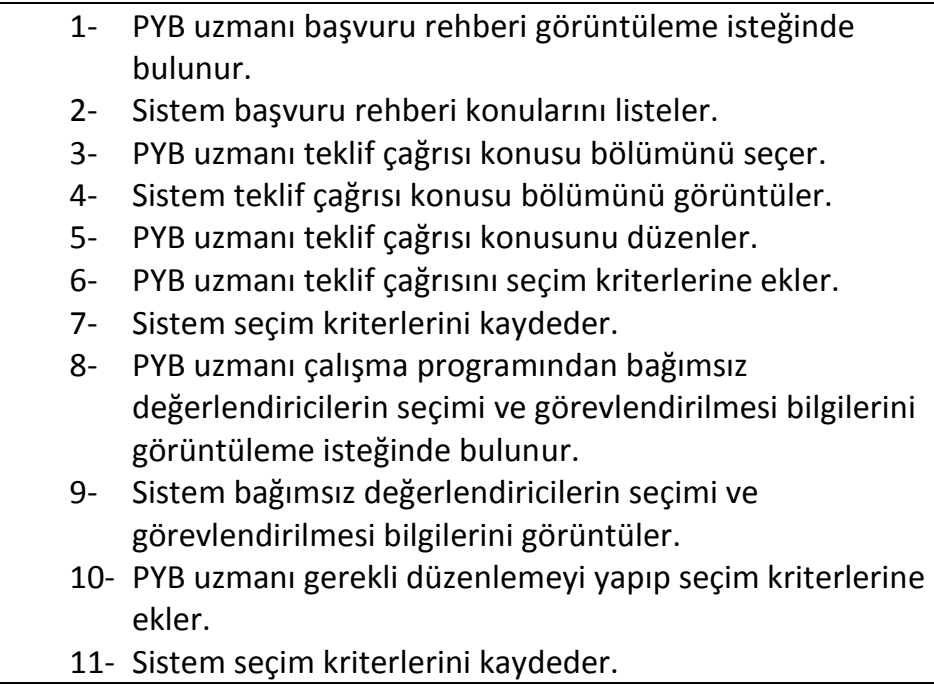 \\
\hline Extensions & $\begin{array}{l}\text { 6-11 a- PYB uzmanı seçim kriterlerini silme isteğinde bulunur. } \\
\text { 1-PYB uzmanı seçim kriterlerini seçer. } \\
\text { 2- PYB uzmanı seçilen seçim kriterlerini siler. } \\
\text { 3- Sistem değişikleri kayıt eder. }\end{array}$ \\
\hline & $\begin{array}{l}\text { 6-11 b- PYB uzmanı seçim kriterlerini değiştirme isteğinde } \\
\text { bulunur. }\end{array}$ \\
\hline & $\begin{array}{l}\text { 1- } \quad \text { PYB uzmanı seçim kriterlerini değiştirir. } \\
\text { 2- } \quad \text { Sistem değişiklikleri kaydeder. }\end{array}$ \\
\hline
\end{tabular}




\begin{tabular}{|c|c|}
\hline Use Case & \#2: BD ilan metninin oluşturulması \\
\hline Primary Actor & PYB Uzmanı \\
\hline Stakeholders & PYB Uzmanı \\
\hline Minimal Guarantees & - \\
\hline Success Guarantees & illan metni oluşturuldu. \\
\hline Preconditions & Seçim kriterleri oluşturuldu. \\
\hline Triggers & Seçim kriterleri oluşturuldu. \\
\hline Main Scenario Success & 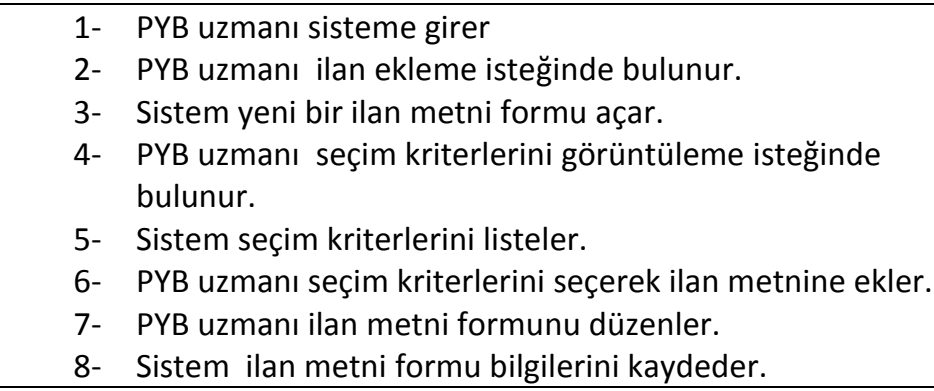 \\
\hline Extensions & 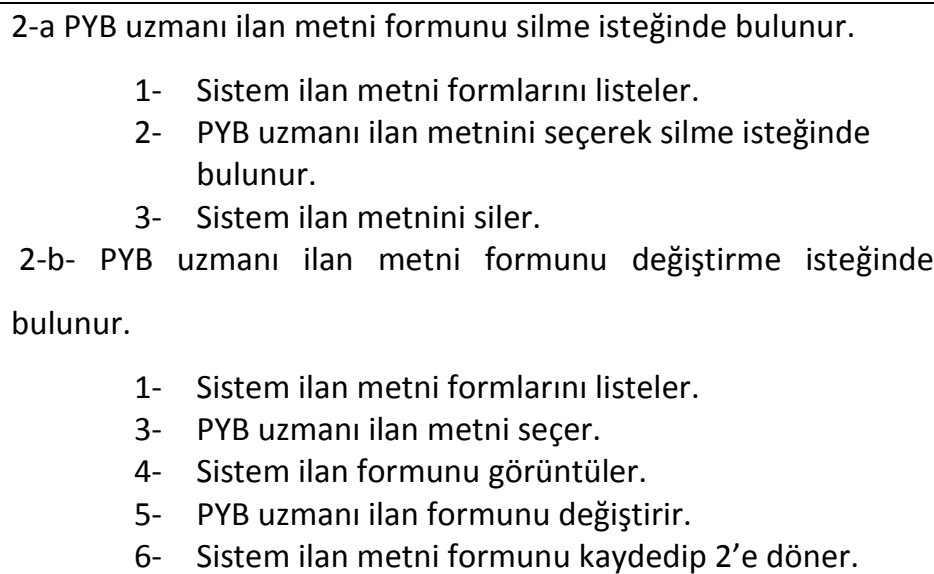 \\
\hline
\end{tabular}

\begin{tabular}{|c|c|}
\hline Use Case & \#3: BD başvuru dökümanlarının oluşturulması \\
\hline Primary Actor & PYB Uzmanı \\
\hline Stakeholders & PYB Uzmanı \\
\hline Minimal Guarantees & - \\
\hline Success Guarantees & BD başvuru dökümanı oluşturuldu. \\
\hline Preconditions & Seçim kriterleri oluşturuldu. \\
\hline Triggers & Seçim kriterleri oluşturuldu. \\
\hline Main Scenario Success & $\begin{array}{l}\text { 1- } \text { PYB uzmanı sisteme girer. } \\
\text { 2- } \quad \text { PYB uzmanı yeni BD başvuru dökümanını oluşturma } \\
\text { isteğinde bulunur. } \\
\text { 3- } \\
\text { 4- }\end{array}$ \\
\hline
\end{tabular}




\begin{tabular}{|c|c|}
\hline & $\begin{array}{ll} & \text { şekilde şablonu doldurur. } \\
\text { 5- } & \text { Sistem şablonu kaydeder. } \\
\text { 6- } & \text { Sistem BD başvuru dökümanını görüntüler. }\end{array}$ \\
\hline Extensions & 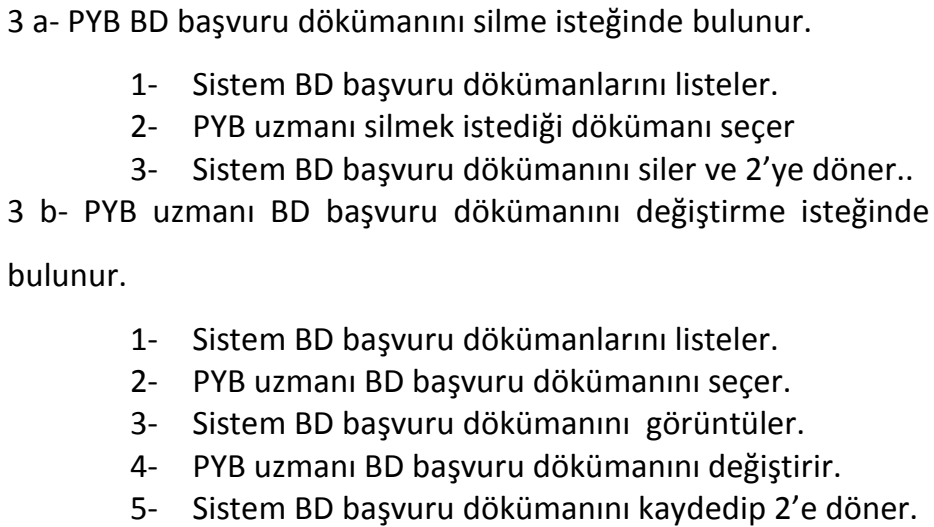 \\
\hline
\end{tabular}

\begin{tabular}{|c|c|}
\hline Use Case & \#4: BD ilan zamanı, ilan araçları, başvuru süresinin planlaması \\
\hline Primary Actor & PYB Uzmanı \\
\hline Stakeholders & PYB Uzmanı \\
\hline Minimal Guarantees & - \\
\hline Success Guarantees & BD alım planı oluşturuldu. \\
\hline Preconditions & Seçim kriterleri oluşturuldu. \\
\hline Triggers & Seçim kriterleri oluşturuldu. \\
\hline Main Scenario Success & $\begin{array}{l}\text { 1- PYB uzmanı sisteme girer } \\
\text { 2- } \quad \text { PYB uzmanı yeni BD alım planını oluşturma isteğinde } \\
\text { bulunur. } \\
\text { 3- } \\
\text { 4- } \\
\text { PYstem alım planı şablonunu görüntüler. } \\
\text { bilgilerini girer. } \\
\text { 5- }\end{array}$ \\
\hline Extensions & 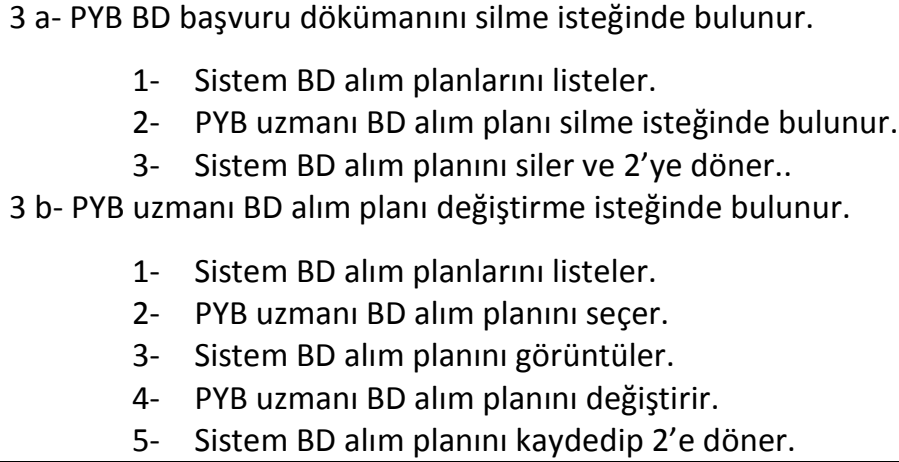 \\
\hline
\end{tabular}




\begin{tabular}{|c|c|}
\hline Use Case & \#5: Çıktıların onaya gönderilmesi \\
\hline Primary Actor & PYB Uzmanı \\
\hline Stakeholders & GS, PYB Uzmanı \\
\hline Minimal Guarantees & - \\
\hline Success Guarantees & Çıktılar onaya gönderildi. \\
\hline Preconditions & BD ilanı, başvuru dökümanları ve alım planı oluşturuldu. \\
\hline Triggers & BD ilanı, başvuru dökümanları ve alım planı oluşturuldu. \\
\hline Main Scenario Success & $\begin{array}{l}\text { 1- } \begin{array}{l}\text { PYB uzmanı BD ilanı, başvuru dökümanları ve alım } \\
\text { planının onaya gönderilmesi isteğinde bulunur. }\end{array} \\
\text { 2- } \begin{array}{l}\text { Sistem BD ilanı, başvuru dökümanları ve alım planılarını } \\
\text { listeler. }\end{array} \\
\text { 3- } \begin{array}{l}\text { PYB uzmanı ilgili BD ilanı, başvuru dökümanları ve alım } \\
\text { planlarını seçer ve onay isteğinde bulunur. }\end{array} \\
\text { 4- } \begin{array}{l}\text { Sistem alım planı şablonunu seçilen BD ilanı, başvuru } \\
\text { dökümanları ve alım planını onay için sorumlu GS'ye } \\
\text { gönderir . }\end{array} \\
\text { 5- } \begin{array}{l}\text { Sistem gönderme zamanı ve onay isteği bilgilerini } \\
\text { kaydeder. }\end{array}\end{array}$ \\
\hline Extensions & - \\
\hline
\end{tabular}

\begin{tabular}{|c|c|}
\hline Use Case & \#6: BD çıktılarının gözden geçirilmesi. \\
\hline Primary Actor & GS uzmanı \\
\hline Stakeholders & GS uzmanı \\
\hline Minimal Guarantees & - \\
\hline Success Guarantees & Çıktılar onaylandı. \\
\hline Preconditions & Çıktılar onaya gönderildi. \\
\hline Triggers & Çıktılar onaya gönderildi. \\
\hline Main Scenario Success & $\begin{array}{l}\text { 1- } \text { GS uzmanı çıktıların listelenmesi isteğinde bulunur. } \\
\text { 2- } \\
\text { Sistem onay isteği, BD başvuru dökümanları, BD alım } \\
\text { planı, BD ilan metni, BD seçim kriterlerini listeler. } \\
\text { 3- } \quad \text { GS uzmanı ilgili dökümanı seçerek görüntüleme } \\
\text { isteğinde bulunur. } \\
\text { 4- } \\
\text { 5- } \\
\text { 6- }\end{array}$ \\
\hline Extensions & $\begin{array}{l}5 \text { a- GS uzmanı dökümandaki eksiklikleri belirler. } \\
\begin{aligned} 1- & \text { Ilgili dökümandaki eksikleri yorum alanına yazar. } \\
\text { 2- } & \text { Sistem yorumları kaydeder } 1 \text { 'e döner. }\end{aligned}\end{array}$ \\
\hline
\end{tabular}




\begin{tabular}{|c|c|}
\hline Use Case & \#7: BD çıktılarının güncellenmesi. \\
\hline Primary Actor & PYB uzmanı \\
\hline Stakeholders & PYB uzmanı \\
\hline Minimal Guarantees & - \\
\hline Success Guarantees & BD çıktıları güncellendi \\
\hline Preconditions & Eksiklikler bulundu. \\
\hline Triggers & Eksiklikler bulundu. \\
\hline Main Scenario Success & $\begin{array}{l}\text { 1- PYB uzmanı çıktıların güncellenmesi isteğinde bulunur. } \\
\text { 2- } \\
\text { Sistem onay isteği, BD başvuru dökümanları, BD alım } \\
\text { planı, BD ilan metni, BD seçim kriterlerini ve onay } \\
\text { durumunu listeler. } \\
\text { 3- } \quad \begin{array}{l}\text { PYB uzmanı ilgili dökümanı seçerek görüntüleme } \\
\text { isteğinde bulunur. }\end{array} \\
\text { 4- Sistem dökümanı ve GS uzmanının yorumlarını } \\
\text { görüntüler. } \\
\text { 5- PYB uzmanı dökümanları günceller. } \\
\text { 6- Sistem dökümanları kaydedip, onaya gönderir. }\end{array}$ \\
\hline Extensions & - \\
\hline
\end{tabular}

\begin{tabular}{|l|l|}
\hline Use Case & \#8: Illan araçlarıyla ilgili hazırlıkların yapılması \\
\hline Primary Actor & PYB uzmanı \\
\hline Stakeholders & PYB uzmanı \\
\hline Minimal Guarantees & - \\
\hline Success Guarantees & Ilan araçları ile ilgili hazırlıklar yapıldı. \\
\hline Preconditions & BD alımı ile ilgili çıktılar onaylandı. \\
\hline Triggers & BD alımı ile ilgili çıktılar onaylandı. \\
\hline Main Scenario Success & $\begin{array}{l}\text { 1- PYB uzmanı ilan araçları bilgisini görüntüleme isteğinde } \\
\text { bulunur. } \\
\text { 2- Sistem ilan araçlarını ve zaman bilgilerini görüntüler. } \\
\text { PYB uzmanı ilgili tarih ve ilan araç bilgilerini düzenler. } \\
\text { 4- Sistem ilan araçları bilgilerini kaydeder. }\end{array}$ \\
\hline Extensions & \begin{tabular}{l} 
\\
\hline
\end{tabular} \\
\hline
\end{tabular}

\begin{tabular}{|l|l|}
\hline Use Case & \#9: BD alım ilanının internet sitesinde yayınlanması. \\
\hline Primary Actor & PYB uzmanı \\
\hline Stakeholders & PYB uzmanı \\
\hline Minimal Guarantees & - \\
\hline
\end{tabular}




\begin{tabular}{|c|c|}
\hline Success Guarantees & BD alım ilanı internet sitesinde yayınlandı. \\
\hline Preconditions & $\begin{array}{l}\text { BD alım planında belirlenen ilan zamanı ve ilan araçları } \\
\text { hazırlıkları yapıldı. }\end{array}$ \\
\hline Triggers & $\begin{array}{l}\text { BD alım planında belirlenen ilan zamanı ve ilan araçları } \\
\text { hazırlıkları yapıldı. }\end{array}$ \\
\hline Main Scenario Success & 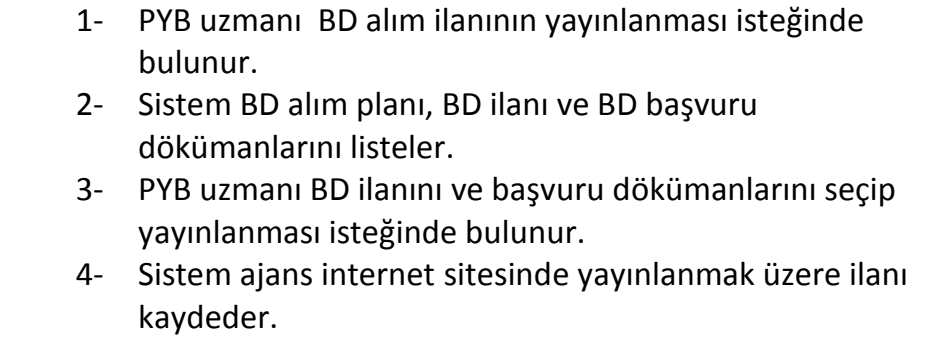 \\
\hline Extensions & - \\
\hline
\end{tabular}

\begin{tabular}{|l|l|}
\hline Use Case & \#10: BD Başvurularının alınması. \\
\hline Primary Actor & BD adayı \\
\hline Stakeholders & BD adayı, PYB uzmanı \\
\hline Minimal Guarantees & - \\
\hline Success Guarantees & BD başvuruları alındı. \\
\hline Preconditions & BD alım ilanı internet sitesinde yayınlandı. \\
\hline Triggers & BD alım ilanı internet sitesinde yayınlandı. \\
\hline Main Scenario Success & $\begin{array}{l}\text { 1- } \quad \text { BD adayı BD başvuru formu doldurma isteğinde } \\
\text { bulunur. } \\
\text { 2- }\end{array}$ \\
& $\begin{array}{l}\text { Sistem BD başvuru formunu görüntüler. } \\
\text { BD adayı başvuru formunu doldurur. } \\
\text { 4- Sistem BD başvuru formunu kaydeder. }\end{array}$ \\
\hline Extensions & $-\quad$ \\
\hline
\end{tabular}

\begin{tabular}{|l|l|}
\hline Use Case & \#11: Seçim komisyonunun belirlenmesi. \\
\hline Primary Actor & GS \\
\hline Stakeholders & GS \\
\hline Minimal Guarantees & - \\
\hline Success Guarantees & seçim komisyonu belirlendi \\
\hline Preconditions & BD alım ilanı internet sitesinde yayınlandı. \\
\hline Triggers & BD alım ilanı internet sitesinde yayınlandı. \\
\hline Main Scenario Success & 1- GS uzmanı seçim komisyonunu belirleme isteğinde \\
\hline
\end{tabular}




\begin{tabular}{|c|c|}
\hline & $\begin{array}{l}\text { bulunur. } \\
\text { 2- Sistem ajans uzmanlarını, birim ve pozisyon bilgileri ile } \\
\text { listeler. } \\
\text { 3- GS uzmanı } 3 \text { tane seçim kurulu komisyonu üyesini } \\
\text { listeden seçer. } \\
\text { 4- } \quad \text { Sistem BD seçim komisyonu üye bilgilerini kaydeder. }\end{array}$ \\
\hline Extensions & $\begin{array}{l}\text { 4-a . üye sayısının } 3 \text { den az seçilmesi ve seçim kurallarına } \\
\text { uyulmaması durumu } \\
\text { 1. Sistem hata mesajı verir. } \\
\text { 2. Sistem } 2 \text {. Adıma geri döner }\end{array}$ \\
\hline
\end{tabular}

\begin{tabular}{|c|c|}
\hline Use Case & \#12: BD başvurularının değerlendirilmesi. \\
\hline Primary Actor & BD seçim komisyonu \\
\hline Stakeholders & BD seçim komisyonu \\
\hline Minimal Guarantees & - \\
\hline Success Guarantees & BD başvuruları değerlendirildi. \\
\hline Preconditions & BD başvuruları alındı ve seçim komisyonu belirlendi. \\
\hline Triggers & BD başvuruları alındı ve seçim komisyonu belirlendi. \\
\hline Main Scenario Success & $\begin{array}{l}\text { 1- } \quad \text { BD seçim komisyonu üyesi BD başvuru değerlendirme } \\
\text { isteğinde bulunur. } \\
\text { 2- } \\
\text { 3- } \quad \text { Sistem BD adaylarını ve seçim kriterlerini listeler. } \\
\text { adaya geçer. } \\
\text { 3-4 bütün adaylar bitene kadar devam eder. } \\
\text { 4- } \quad \text { Sistem seçilen adayları listeler. }\end{array}$ \\
\hline Extensions & $\begin{array}{l}\text { 3-a. BD seçim komisyonu üyesi aday değerlendirme bilgisi } \\
\text { değiştirme isteğinde bulunur. } \\
\text { 1. Sistem aday bilgisini görüntüler. } \\
\text { 2. BD seçim komisyonu üyesi değişiklikleri yapar. } \\
\text { 3. Sistem değişiklikleri kaydeder. }\end{array}$ \\
\hline
\end{tabular}




\begin{tabular}{|c|c|}
\hline Use Case & $\begin{array}{l}\text { \#13: Seçilen BD'lerin onaylanması ve paydaş veri tabanına kayıt } \\
\text { edilmesi }\end{array}$ \\
\hline Primary Actor & GS,PYB \\
\hline Stakeholders & GS,PYB \\
\hline Minimal Guarantees & - \\
\hline Success Guarantees & Seçilen BD’ler onaylandı ve paydaş veri tabanına kayıt edildi \\
\hline Preconditions & BD başvuruları değerlendirildi. \\
\hline Triggers & BD başvuruları değerlendirildi. \\
\hline Main Scenario Success & $\begin{array}{l}\text { 1- GS uzmanı seçilen adayları onaylama isteğinde bulunur. } \\
\text { 2- Sistem seçilen BD listesini görüntüler. } \\
\text { 3- } \text { GS uzmanı BD listesini onaylar. } \\
\text { 4- } \quad \text { Sistem onayı kaydeder. } \\
\text { 5- PYB uzmanı onaylanan seçilen BD’leri paydas veri } \\
\text { tabanına aktarma isteğinde bulunur. } \\
\text { 6- System BD’leri paydaş veri tabanına kaydeder. }\end{array}$ \\
\hline Extensions & $\begin{array}{l}\text { 3-a. GS uzmanı seçilen BD lerin yeniden değelendirmesi isteğinde } \\
\text { bulunur. } \\
\text { 1. Sistem BD seçim komisyonu üyelerini uyarır 1'e döner }\end{array}$ \\
\hline
\end{tabular}

\begin{tabular}{|c|c|c|c|}
\hline FP\# & FP name & $\begin{array}{l}\text { Data } \\
\text { Mov. }\end{array}$ & OOI/Data Group \\
\hline \multirow[t]{11}{*}{1} & \multirow[t]{11}{*}{ BD seçim kriterlerinin oluşturulması } & & \\
\hline & & $\mathrm{E}$ & Bd seçim kriterleri oluşturma isteği \\
\hline & & $E$ & Başvuru rehberi \\
\hline & & $\mathrm{R}$ & Başvuru rehberi \\
\hline & & $x$ & Başvuru rehberi \\
\hline & & $\mathrm{E}$ & Teklif çağrısı \\
\hline & & $\mathrm{R}$ & Teklif çağrısı \\
\hline & & $\mathrm{x}$ & Teklif çağrısı \\
\hline & & $\mathrm{R}$ & Çalışma programı \\
\hline & & W & Bd seçim kriterleri \\
\hline & & $x$ & Hata bilgisi \\
\hline \multirow[t]{3}{*}{2} & \multirow[t]{3}{*}{ BD seçim kriterlerinin listelenmesi } & $E$ & Seçim kriterleri parametresi \\
\hline & & $\mathrm{R}$ & Seçim kriterleri \\
\hline & & $x$ & Seçim kriterleri \\
\hline
\end{tabular}




\begin{tabular}{|c|c|c|c|}
\hline FP\# & FP name & $\begin{array}{l}\text { Data } \\
\text { Mov. }\end{array}$ & OOI/Data Group \\
\hline \multirow[t]{2}{*}{3} & \multirow[t]{2}{*}{ BD seçim kriterlerinin silinmesi } & $E$ & Seçim kriterleri parametresi \\
\hline & & W & Seçim kriterleri \\
\hline \multirow[t]{2}{*}{4} & \multirow[t]{2}{*}{$\begin{array}{l}\text { BD seçim } \quad \text { kriterlerinin } \\
\text { güncellenmesi }\end{array}$} & $E$ & Seçim kriterleri parametresi \\
\hline & & W & Seçim kriterleri \\
\hline \multirow[t]{7}{*}{5} & \multirow[t]{7}{*}{ BD ilan metninin oluşturulması } & $\mathrm{E}$ & Bd ilan metni isteği \\
\hline & & $\mathrm{R}$ & Seçim kriterleri bilgisi \\
\hline & & $x$ & Seçim kriterleri bilgisi \\
\hline & & $\mathrm{E}$ & Seçim kriterleri bilgisi \\
\hline & & $\mathrm{E}$ & Bd ilan metni bilgisi \\
\hline & & W & Bd ilan metni bilgisi \\
\hline & & $\mathrm{x}$ & Bd ilan metni bilgisi \\
\hline \multirow[t]{3}{*}{6} & \multirow[t]{3}{*}{ BD ilan metninin listelenmesi } & $E$ & Bd ilan metni listeleme isteği \\
\hline & & $\mathrm{R}$ & Bd ilan metinleri bilgisi \\
\hline & & $x$ & Bd ilan metinleri bilgisi \\
\hline \multirow[t]{2}{*}{7} & \multirow[t]{2}{*}{ BD ilan metninin silinmesi } & $\mathrm{E}$ & Ilan metni parametresi \\
\hline & & W & Ilan metni bilgisi \\
\hline \multirow[t]{2}{*}{8} & \multirow[t]{2}{*}{ BD ilan metninin güncellenmesi } & $E$ & Ilan metni parametresi \\
\hline & & W & Ilan metni bilgisi \\
\hline \multirow[t]{6}{*}{9} & \multirow[t]{6}{*}{$\begin{array}{l}\text { BD Başvuru dökümanlarının } \\
\text { oluşturulması }\end{array}$} & $\mathrm{E}$ & $\begin{array}{l}\text { Bd başvuru dökümanları oluşturma } \\
\text { isteği }\end{array}$ \\
\hline & & $\mathrm{R}$ & Bd başvuru döküman alanları \\
\hline & & $x$ & Bd başvuru döküman alanları \\
\hline & & $\mathrm{E}$ & Başvuru döküman alan bilgisi \\
\hline & & W & Bd başvuru döküman alan bilgisi \\
\hline & & & \\
\hline
\end{tabular}




\begin{tabular}{|c|c|c|c|}
\hline FP\# & FP name & $\begin{array}{l}\text { Data } \\
\text { Mov. }\end{array}$ & OOI/Data Group \\
\hline \multirow[t]{3}{*}{10} & \multirow[t]{3}{*}{$\begin{array}{l}\text { BD başvuru dökman alanlarının } \\
\text { listelenmesi }\end{array}$} & $E$ & Bd başvuru döküman alan bilgisi \\
\hline & & $\mathrm{R}$ & Bd başvuru döküman alan bilgisi \\
\hline & & $x$ & Bd başvuru döküman alan bilgisi \\
\hline \multirow[t]{2}{*}{11} & \multirow[t]{2}{*}{$\begin{array}{l}\text { BD başvuru döküman alanlarının } \\
\text { silinmesi }\end{array}$} & $\mathrm{E}$ & Bd başvuru döküman alan bilgisi \\
\hline & & W & Bd başvuru döküman alan bilgisi \\
\hline \multirow[t]{2}{*}{12} & $\begin{array}{l}\text { BD başvuru döküman alanlarının } \\
\text { güncellenmesi }\end{array}$ & $\mathrm{E}$ & Bd başvuru döküman alan bilgisi \\
\hline & & W & Bd başvuru döküman alan bilgisi \\
\hline \multirow[t]{2}{*}{13} & \multirow[t]{2}{*}{$\begin{array}{l}\text { BD ilan zamanı, ilan araçları, } \\
\text { başvuru süresinin planlanması }\end{array}$} & $\mathrm{E}$ & Alım planı bilgisi \\
\hline & & W & Alım planı bilgisi \\
\hline \multirow[t]{3}{*}{14} & \multirow[t]{3}{*}{ BD alım planının listelenmesi } & $\mathrm{E}$ & Bd alım planı \\
\hline & & $\mathrm{R}$ & Bd alım planı \\
\hline & & $x$ & Bd alım planı \\
\hline \multirow[t]{2}{*}{15} & \multirow[t]{2}{*}{ BD alım planının silinmesi } & $\mathrm{E}$ & Alım planı parametresi \\
\hline & & W & Alım planı bilgisi \\
\hline \multirow[t]{2}{*}{16} & \multirow[t]{2}{*}{ BD alım planının güncellenmesi } & $E$ & Alım planı parametresi \\
\hline & & W & Alım planı bilgisi \\
\hline \multirow[t]{5}{*}{17} & \multirow[t]{5}{*}{ Çıktıların onaya gönderilmesi } & $E$ & Onay isteği \\
\hline & & $\mathrm{R}$ & Çıktı dökümanları bilgisi \\
\hline & & $x$ & Çıktı dökümanları bilgisi \\
\hline & & $E$ & Çıktı dökümanları bilgisi-onay \\
\hline & & W & Çıktı dökümanları bilgisi-onay \\
\hline
\end{tabular}




\begin{tabular}{|c|c|c|c|}
\hline FP\# & FP name & $\begin{array}{l}\text { Data } \\
\text { Mov. }\end{array}$ & OOI/Data Group \\
\hline \multirow{15}{*}{18} & \multirow{15}{*}{ BD çıktılarının gözden geçirilmesi } & $E$ & \\
\hline & & & Çıktı bilgileri görüntüleme isteği \\
\hline & & $\mathrm{R}$ & $\begin{array}{l}\text { Çıktı bilgileri (başvuru dök., alım } \\
\text { planı, ilan metni, seçim kriterleri) }\end{array}$ \\
\hline & & $x$ & $\begin{array}{l}\text { Çıktı bilgileri (başvuru dök., alım } \\
\text { planı, ilan metni, seçim kriterleri) }\end{array}$ \\
\hline & & $\mathrm{R}$ & Onay bilgisi \\
\hline & & $\mathrm{R}$ & Bd başvuru dökümanları \\
\hline & & $\mathrm{R}$ & Bd alım planı \\
\hline & & $\mathrm{R}$ & Bd ilan metni \\
\hline & & $\mathrm{R}$ & Bd seçim kriterleri \\
\hline & & $x$ & Onay bilgisi \\
\hline & & $x$ & Bd başvuru dökümanları \\
\hline & & $x$ & Bd alım planı \\
\hline & & $\mathrm{X}$ & Bd ilan metni \\
\hline & & $x$ & Bd seçim kriterleri \\
\hline & & W & Onay bilgisi \\
\hline \multirow[t]{16}{*}{19} & \multirow[t]{16}{*}{ BD çıktılarının güncellenmesi } & $E$ & Çıktı bilgileri görüntüleme isteği \\
\hline & & $\mathrm{R}$ & Onay durum bilgisi \\
\hline & & $\mathrm{R}$ & Bd başvuru dökümanları \\
\hline & & $\mathrm{R}$ & Bd alım planı \\
\hline & & $\mathrm{R}$ & Bd ilan metni \\
\hline & & $\mathrm{R}$ & Seçim kriterleri \\
\hline & & $x$ & Onay durum bilgisi \\
\hline & & $x$ & Bd başvuru dökümanları \\
\hline & & $x$ & Bd alım planı \\
\hline & & $x$ & Bd ilan metni \\
\hline & & $x$ & Seçim kriterleri \\
\hline & & $\mathrm{E}$ & Bd başvuru dökümanları \\
\hline & & $\mathrm{E}$ & Bd alım planı \\
\hline & & $\mathrm{E}$ & Bd ilan metni \\
\hline & & $E$ & Bd seçim kriterleri \\
\hline & & W & Bd başvuru dökümanları \\
\hline
\end{tabular}




\begin{tabular}{|c|c|c|c|}
\hline FP\# & FP name & $\begin{array}{l}\text { Data } \\
\text { Mov. }\end{array}$ & OOI/Data Group \\
\hline & & W & Bd alım planı \\
\hline & & W & Bd ilan metni \\
\hline & & W & Bd seçim kriterleri \\
\hline \multirow[t]{3}{*}{20} & \multirow[t]{3}{*}{$\begin{array}{l}\text { Ilan araçlarıyla ilgili hazırlık } \\
\text { yapılması }\end{array}$} & $E$ & Ilan araçları bilgisi isteği \\
\hline & & $\mathrm{R}$ & Bd alım planı bilgisi \\
\hline & & $\mathrm{x}$ & Ilan araçları bilgisi \\
\hline \multirow[t]{11}{*}{21} & \multirow[t]{11}{*}{$\begin{array}{l}\text { BD alım ilanının internet sitesinde } \\
\text { yayınlanması }\end{array}$} & $E$ & İnternet ilanı isteği \\
\hline & & $\mathrm{R}$ & $\begin{array}{l}\text { Internet ilanı bilgisi( başvuru } \\
\text { dökümanları, alım planı, ilan metni) }\end{array}$ \\
\hline & & $x$ & $\begin{array}{l}\text { Internet ilanı bilgisi( başvuru } \\
\text { dökümanları, alım planı, ilan metni) }\end{array}$ \\
\hline & & $\mathrm{R}$ & Bd başvuru dökümanları \\
\hline & & $\mathrm{R}$ & Bd alım planı \\
\hline & & $\mathrm{R}$ & Bd ilan metni \\
\hline & & $\mathrm{R}$ & Bd seçim kriterleri \\
\hline & & $x$ & Bd başvuru dökümanları \\
\hline & & $x$ & Bd alım planı \\
\hline & & $x$ & Bd ilan metni \\
\hline & & $x$ & Bd seçim kriterleri \\
\hline \multirow[t]{4}{*}{22} & \multirow[t]{4}{*}{ Başvuruların alınması } & $\mathrm{E}$ & Başvuru alınması isteği \\
\hline & & $\mathrm{R}$ & Başvuru dökümanları \\
\hline & & $E$ & Başvuru aday bilgisi \\
\hline & & W & Başvuru aday bilgisi \\
\hline \multirow[t]{5}{*}{23} & \multirow[t]{5}{*}{ Seçim komisyonun belirlenmesi } & $\mathrm{E}$ & Seçim komisyonu parametre bilgisi \\
\hline & & $\mathrm{R}$ & Seçim komisyonu üyeleri \\
\hline & & $x$ & Seçim komisyonu üyeleri \\
\hline & & $\mathrm{E}$ & Seçim komisyonu bilgisi \\
\hline & & W & Seçim komisyonu bilgisi \\
\hline
\end{tabular}




\begin{tabular}{|c|c|c|c|}
\hline FP\# & FP name & $\begin{array}{l}\text { Data } \\
\text { Mov. }\end{array}$ & OOI/Data Group \\
\hline \multirow[t]{13}{*}{24} & \multirow[t]{13}{*}{ BD başvuru değerlendirme } & $E$ & Değerlendirme isteği \\
\hline & & $\mathrm{R}$ & Bd seçim kriterleri \\
\hline & & $x$ & Bd seçim kriterleri \\
\hline & & $\mathrm{R}$ & Bd başvuru bilgisi \\
\hline & & $x$ & Bd başvuru bilgisi \\
\hline & & $E$ & Onay isteği \\
\hline & & W & Onay isteği \\
\hline & & $\mathrm{E}$ & Kabul listesi \\
\hline & & W & Kabul listesi \\
\hline & & $\mathrm{E}$ & Seçim komisyonu raporu \\
\hline & & W & Seçim komisyonu raporu \\
\hline & & $\mathrm{E}$ & $\mathrm{Bd}$ \\
\hline & & W & $\mathrm{Bd}$ \\
\hline \multirow[t]{12}{*}{25} & \multirow[t]{11}{*}{$\begin{array}{l}\text { Seçilen BD lerin onaylanması ve } \\
\text { kayıt }\end{array}$} & $E$ & Onaylama isteği \\
\hline & & $\mathrm{R}$ & Onay bilgisi \\
\hline & & $x$ & Onay bilgisi \\
\hline & & $\mathrm{R}$ & Kabul listesi onay bilgisi \\
\hline & & $x$ & Kabul listesi onay bilgisi \\
\hline & & $\mathrm{E}$ & Kabul listesi onay bilgisi \\
\hline & & W & Kabul listesi onay bilgisi \\
\hline & & $\mathrm{E}$ & Onay durumu \\
\hline & & W & Onay durumu \\
\hline & & $E$ & $\mathrm{Bd}$ \\
\hline & & W & $\mathrm{Bd}$ \\
\hline & Toplam CFP & 137 & \\
\hline
\end{tabular}


ÖDEMELERIN GERÇEKLEŞTIRILIMESI SÜRECi

\begin{tabular}{|c|c|}
\hline Use Case & $\begin{array}{l}\text { \#1: Ön ödeme, ara ödeme ve nihai ödeme oranlarının } \\
\text { belirlenmesi }\end{array}$ \\
\hline Primary Actor & İDB uzmanı \\
\hline Stakeholders & İB uzmanı \\
\hline Minimal Guarantees & - \\
\hline Success Guarantees & Ödeme oranları belirlendi \\
\hline Preconditions & - \\
\hline Triggers & Sözleşme imzalama dönemi tamamlandı \\
\hline $\begin{array}{l}\text { Main Scenario } \\
\text { Success }\end{array}$ & 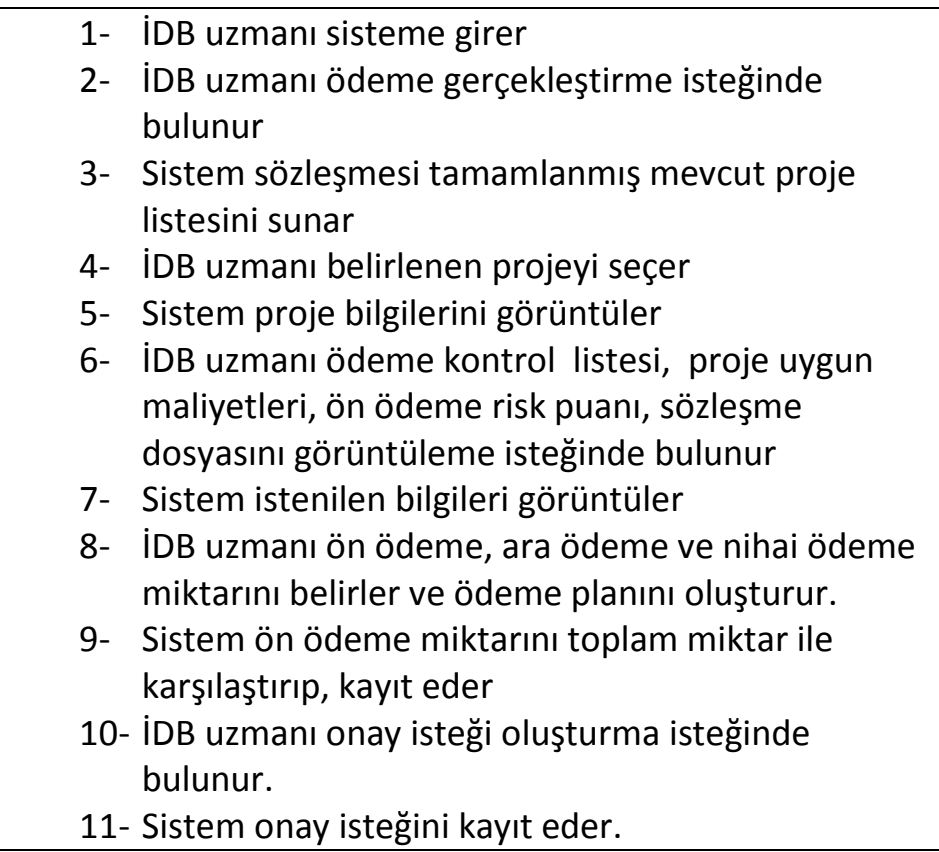 \\
\hline Extensions & $\begin{array}{l}\text { 9a sistem hata verir, gerekli koşulların sağlanmadığına dair } \\
\text { 1. iDB uzmanı hata mesajını görüntüler } \\
\text { 2. Sistem ön ödeme miktarının alt ve üst sınııını gösterir } \\
\text { 3. iDB uzmanı yeni ön ödeme miktarını sisteme girer } \\
\text { 1a sistem hata verir } \\
\text { 9a.1. den devam eder } \\
\text { 4. MSS da } 9 \text { dan devam eder } \\
\text { 8a iDB uzmanı ön ödeme miktarını değiştirmek ister } \\
\text { 1. Sistem değişiklikleri kayıt eder. } \\
3 \text { den devam eder }\end{array}$ \\
\hline
\end{tabular}


8b iDB uzmanı ön ödeme miktarını silmek ister

1. Sistem ön ödeme miktarını siler 3 den devam eder

\begin{tabular}{|c|c|}
\hline Use Case & \#2: Ödeme oranlarının onaylanması \\
\hline Primary Actor & GS uzmanı \\
\hline Stakeholders & GS uzmanı \\
\hline Minimal Guarantees & - \\
\hline Success Guarantees & ön ödeme oranı onaylandı, azaltıldı, artırıldı, iptal edildi. \\
\hline Preconditions & ödeme oranları belirlendi \\
\hline Triggers & ödeme oranları belirlendi \\
\hline $\begin{array}{ll}\text { Main } & \text { Scenario } \\
\text { Success } & \end{array}$ & $\begin{array}{l}\text { 1- GS uzmanı sisteme girer } \\
\text { 2- } \text { GS uzmanı onay isteklerini görüntüleme isteğinde } \\
\text { bulunur } \\
\text { 3- Sistem onay isteklerini listeler } \\
\text { 4- GS uzmanı onay isteği detaylarını görüntüleme } \\
\text { isteğinde bulunur, } \\
\text { 5- Sistem onay isteği detaylarını görüntüler } \\
\text { 6- GS uzmanı ön ödeme miktarı ve ödeme planını } \\
\text { görüntüleme isteğinde bulunur } \\
\text { 7- Sistem ön ödeme miktarını ve ödeme planını } \\
\text { sunar } \\
\text { 8- GS uzmanı onay durumunu yaratır } \\
\text { 9- Sistem kayıt eder. }\end{array}$ \\
\hline Extensions & $\begin{array}{l}\text { 8a GS uzmanı ön ödeme miktarının azaltılmasını ister } \\
\text { 1. Sistem uyarı verir. } \\
\text { 2. GS uzmanı ödeme planını görüntüleme isteğinde } \\
\text { bulunur. } \\
\text { 3. Sistem ödeme planını görüntüler } \\
\text { 4. GS uzmanı ön ödeme oranı değişikliği bilgisini } \\
\text { yaratır. } \\
\text { 5. Sistem değişiklik bilgisini ödeme planına yansıtarak } \\
\text { yararlanıcıya bilgi verir } \\
\text { 8b GS uzmanı ön ödeme miktarının artırılmasını ister. } \\
\text { 1. 8a. 1. den devam eder } \\
\text { 8c GS uzmanı ön ödeme miktarının iptalini ister. } \\
\text { 1. 8a.1. den devam eder } \\
\text { 8d GS onay durumunu değiştirmek ister }\end{array}$ \\
\hline
\end{tabular}


1. Sistem değişiklikleri kayıt edip 3 ' döner

8e GS onay durumunu silmek ister

1. Sistem değişiklikleri kayıt eder 3'e döner

\begin{tabular}{|c|c|}
\hline Use Case & \#3: Başvuru sahibinden ön ödeme talebi alınması \\
\hline Primary Actor & Yararlanıcı \\
\hline Stakeholders & Yararlanıcı \\
\hline Minimal Guarantees & - \\
\hline Success Guarantees & Başvuru sahibinden ön ödeme talebi alındı. \\
\hline Preconditions & \\
\hline Triggers & \\
\hline $\begin{array}{ll}\text { Main Scenario } \\
\text { Success }\end{array}$ & $\begin{array}{ll}\text { 1- } & \text { Yararlanıcı sisteme girer. } \\
\text { 2- } & \text { Yararlanıcı ön ödeme talebi oluşturma isteğinde } \\
& \text { bulunur } \\
\text { 3- } & \text { Sistem ödeme talebi şartlarını görüntüler } \\
\text { 4- } & \text { Yararlanıcı ödeme şartlarına uygunluğunu kabul } \\
& \text { eder. } \\
\text { 5- } & \text { Sistem ön ödeme talebini kayıt eder. } \\
\text { 6- } & \text { Yararlanıcı teminat bilgilerini girer } \\
\text { 7- } & \text { Sistem teminat bilgilerini kontrol eder. } \\
\text { 8- } & \text { Sistem teminat bilgilerini kayıt eder. }\end{array}$ \\
\hline Extensions & $\begin{array}{l}\text { 8a . sistem hata mesajı verir, teminatın uygun } \\
\text { olmadığına dair } \\
\text { 1. Yararlanıcı teminat bilgilerini tekrar girer } \\
7 \text { den devam eder } \\
\text { 6a yararlanıcı teminat bilgilerini değiştirmek ister } \\
\text { 1. Sistem değişiklikleri kayıt eder } 3 \text { 'e döner } \\
\text { 6b yararlanıcı teminat bilgilerini silmek ister } \\
\text { 1. Sistem değişiklikleri kayıt eder } 3 \text { 'e döner }\end{array}$ \\
\hline
\end{tabular}

\begin{tabular}{|l|l|}
\hline Use Case & \#4: Ön ödeme miktarının hesap numarasına aktarılması. \\
\hline Primary Actor & IDB Uzmanı \\
\hline Stakeholders & iDB Uzmanı \\
\hline
\end{tabular}




\begin{tabular}{|l|l|}
\hline Minimal Guarantees & - \\
\hline Success Guarantees & Ön ödeme gerçekleştirildi \\
\hline Preconditions & Teminat var \\
\hline Triggers & Scenario \\
\hline Main & $\begin{array}{l}\text { 1- IDB Uzmanı Proje detaylarını seçer } \\
\text { 3- }\end{array}$ \\
Success & IDB Uzmanı belirtilen hesap numarasına ön \\
& ödeme talimatı oluşturur. \\
& Sistem muhasebe departmanına ödeme talimatını \\
& \\
\hline Extensions & \\
\hline
\end{tabular}

\begin{tabular}{|c|c|}
\hline Use Case & $\begin{array}{l}\text { \#5: hakediş esasına göre ön ödeme harcamalarını } \\
\text { değerlendirme }\end{array}$ \\
\hline Primary Actor & İDB Uzmanı \\
\hline Stakeholders & İDB Uzmanı \\
\hline Minimal Guarantees & - \\
\hline Success Guarantees & $\begin{array}{l}\text { Ön ödeme miktarı kullanılmamış, ön ödeme miktarı } \\
\text { kullanıımamış }\end{array}$ \\
\hline Preconditions & Ön ödeme gerçekleştirildi \\
\hline Triggers & \\
\hline $\begin{array}{l}\text { Main } \\
\text { Success }\end{array}$ & $\begin{array}{l}\text { 1- } \text { IDB Uzmanı sisteme girer } \\
\text { 2- } \text { iDB Uzmanı proje detaylarını görüntüleme } \\
\text { isteğinde bulunur } \\
\text { 3- } \text { Sistem proje detaylarını görüntüler. } \\
\text { 4- } \text { iDB Uzmanı eş finansman oranı, ön ödeme miktarı, } \\
\text { ödeme talebi, ödeme planı, ara dönem hakediş } \\
\text { miktarını ve ödeme kontrol listesini görüntüleme } \\
\text { isteğinde bulunur } \\
\text { 5- Sistem eş finansman oranı, ön ödeme miktarı, } \\
\text { ödeme talebi, ödeme planı, ara dönem hakediş } \\
\text { miktarını ve ödeme kontrol listesini görüntüler } \\
\text { 6- iDB Uzmanı ön ödemenin kapatılması isteğinde } \\
\text { bulunur. } \\
\text { 7- Sistem ödeme planını görüntüler } \\
\text { 8- } \text { iDB Uzmanı ödeme planının değiştirir } \\
\text { 9- Sistem değişikliği kayıt eder. }\end{array}$ \\
\hline
\end{tabular}




\begin{tabular}{|c|c|}
\hline Extensions & $\begin{array}{l}\text { 6a iDB Uzmanı ön ödemede kalan harcanmamış miktarı } \\
\text { tespit eder } \\
\text { 1. iDB Uzmanı ön ödeme miktarı ve ara dönem } \\
\text { hakediş miktarını görüntüleme isteğinde bulunur. } \\
\text { 2. Sistem ön ödeme miktarını ve ara dönem hakediş } \\
\text { miktarını görüntüler } \\
\text { 3. iDB Uzmanı hakediş gerçekleşmemiş ödeme } \\
\text { miktarını oluşturur } \\
\text { 3a- hakediş gerçekleşmemiş ödeme miktarını } \\
\text { değiştirmek ister } \\
\text { 1. Sistem değişiklikleri kayıt eder } \\
\text { 3b -hakediş gerçekleşmemiş ödeme miktarını } \\
\text { silmek ister } \\
\text { 1. Sistem değişiklikleri kayıt eder } \\
\text { 4. Sistem kayıt eder. }\end{array}$ \\
\hline
\end{tabular}

\begin{tabular}{|c|c|}
\hline Use Case & \#6: Ara ödeme miktarının oluşturulması \\
\hline Primary Actor & IDB Uzmanı \\
\hline Stakeholders & IDB Uzmanı \\
\hline Minimal Guarantees & - \\
\hline Success Guarantees & Ara ödeme miktarı belirlendi \\
\hline Preconditions & Ön ödeme kapatıldı \\
\hline Triggers & Ön ödeme kapatıldı \\
\hline $\begin{array}{l}\text { Main } \quad \text { Scenario } \\
\text { Success }\end{array}$ & $\begin{array}{l}\text { 1- IDB Uzmanı sisteme girer } \\
\text { 2- } \text { iDB Uzmanı proje detaylarını görüntüleme } \\
\text { isteğinde bulunur } \\
\text { 3- } \\
\text { 4- } \text { istem proje detaylarını görüntüler } \\
\text { proje uygun maliyetleri görüntüleme isteğinde } \\
\text { bulunur } \\
\text { 5- Sistem eş finansman oranı, başvuru rehberi ve } \\
\text { proje uygun maliyetleri görüntüler } \\
\text { 6- } \quad \text { iDB Uzmanı ödeme planı görüntüleme isteğinde } \\
\text { bulunur } \\
\text { 7- Sistem ödeme planını görüntüler } \\
\text { 8- iDB Uzmanı ödeme planını değiştirir } \\
\text { 9- Sistem değişikliği kayıt eder } \\
\text { 10- iDB Uzmanı onay isteği oluşturur } \\
\text { 11- Sistem onay isteğini kayıt eder }\end{array}$ \\
\hline
\end{tabular}




\begin{tabular}{|l|c|}
\hline Extensions & $\begin{array}{c}\text { 10a -iDB uzmanı onay isteğini değiştirmek ister } \\
1 . \quad \text { Sistem değişiklikleri kayıt eder } \\
\text { 10b- IDB uzmanı onay isteğini silmek ister }\end{array}$ \\
\hline
\end{tabular}

\begin{tabular}{|c|c|}
\hline Use Case & $\begin{array}{l}\text { \#7: Ara dönem ödeme miktarının onaylanması ve hesaba } \\
\text { transferi }\end{array}$ \\
\hline Primary Actor & iDB Uzmanı, GS \\
\hline Stakeholders & İDB Uzmanı, GS, yararlanıcı \\
\hline Minimal Guarantees & - \\
\hline Success Guarantees & Ara ödeme miktarı yararlanıcı hesabına aktarıldı. \\
\hline Preconditions & Ara dönem ödeme miktarı tespit edildi \\
\hline \multicolumn{2}{|l|}{ Triggers } \\
\hline $\begin{array}{ll}\text { Main } & \text { Scenario } \\
\text { Success }\end{array}$ & $\begin{array}{l}\text { 1- GS sisteme girer } \\
\text { 2- GS onay isteklerini görüntüleme isteğinde bulunur } \\
\text { 3- } \text { Sistem onay isteklerini görüntüler } \\
\text { 4- } \text { GS ara dönem ödeme miktarı ödeme planı ve onay } \\
\text { isteği yazısını görüntüleme isteğinde bulunur } \\
\text { 5- } \quad \text { Sistem ara dönem ödeme miktarı ödeme planı ve } \\
\text { onay isteği yazısını görüntüler. } \\
\text { 6- GS onay Durumu oluşturur } \\
\text { 7- Sistem onay durumunu kayıt eder } \\
\text { 8- iDB uzmanı onay durumlarını görüntüleme } \\
\text { isteğinde bulunur. } \\
\text { 9- Sistem onay durumlarını görüntüler } \\
\text { 10- iDB uzmanı onaylanmış miktarları sözleşme hesap } \\
\text { numaralarına aktarır } \\
\text { 11- Sistem para aktarma işlemini kayıt eder. }\end{array}$ \\
\hline Extensions & 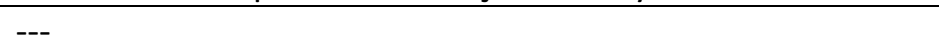 \\
\hline
\end{tabular}




\begin{tabular}{|c|c|}
\hline Use Case & \#8: Proje toplam uygun maliyetlerinin belirlenmesi \\
\hline Primary Actor & iDB uzmanı \\
\hline Stakeholders & iDB uzmanı \\
\hline Minimal Guarantees & - \\
\hline Success Guarantees & Eş finansman gerçekleşme oranı saptandı \\
\hline Preconditions & Ara veya nihai rapor incelenmesi tamamlandı \\
\hline Triggers & Proje ara ödemesi gerçekleşti \\
\hline $\begin{array}{ll}\text { Main } & \text { Scenario } \\
\text { Success } & \end{array}$ & 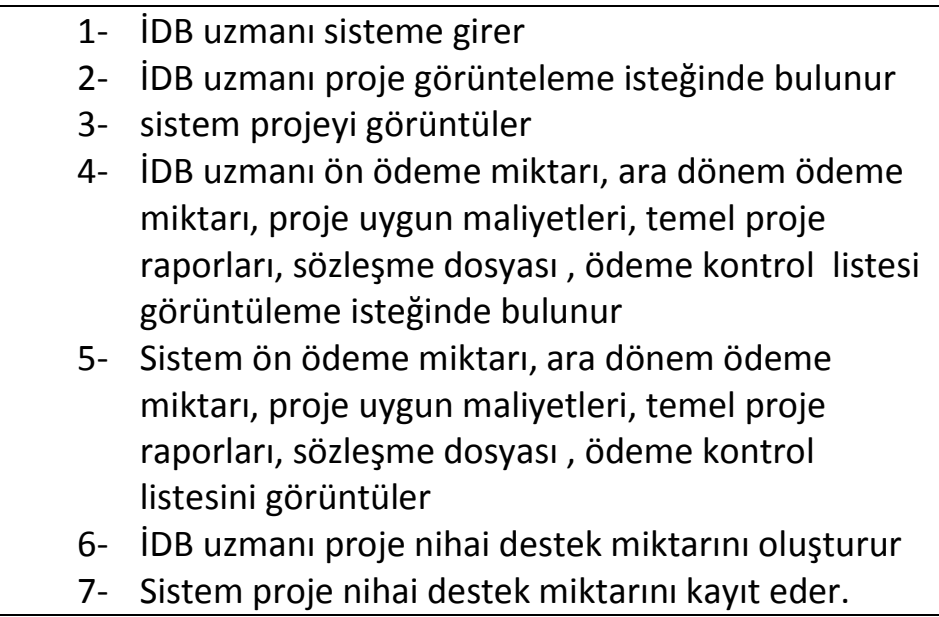 \\
\hline Extensions & $\begin{array}{l}\text { 6a - IDB uzmanı nihai destek miktarını değiştirmek ister } \\
\text { 1. Sistem değişiklikleri kayıt eder } \\
\text { 6b- iDB uzmanı nihai destek miktarını silmek ister } \\
\text { 1. Sistem değişiklikleri kayıt eder } \\
\text { 7a sistem eş finansman gerçekleşme oranı hakkında hata } \\
\text { verir } \\
\text { 1. iDB uzmanı başvuru rehberini görüntüleme } \\
\text { isteğinde bulunur } \\
\text { 2. Sistem başvuru rehberini görüntüler } \\
\text { 3. iDB uzmanı eş finansman gerçekleşme oranında } \\
\text { proje nihai destek miktarını indirir } \\
\text { 4. Sistem yeni proje destek miktarını kayıt eder. }\end{array}$ \\
\hline
\end{tabular}

\begin{tabular}{|l|l|}
\hline Use Case & $\# 9:$ Nihai ödemenin belirlenmesi \\
\hline Primary Actor & iDB uzmanı \\
\hline Stakeholders & iDB uzmanı \\
\hline
\end{tabular}




\begin{tabular}{|c|c|}
\hline Minimal Guarantees & - \\
\hline Success Guarantees & Nihai ödeme miktarı belirlendi \\
\hline Preconditions & Toplam ödeme miktarı belirlendi \\
\hline Triggers & Toplam ödeme miktarı belirlendi \\
\hline $\begin{array}{ll}\text { Main } & \text { Scenario } \\
\text { Success } & \end{array}$ & 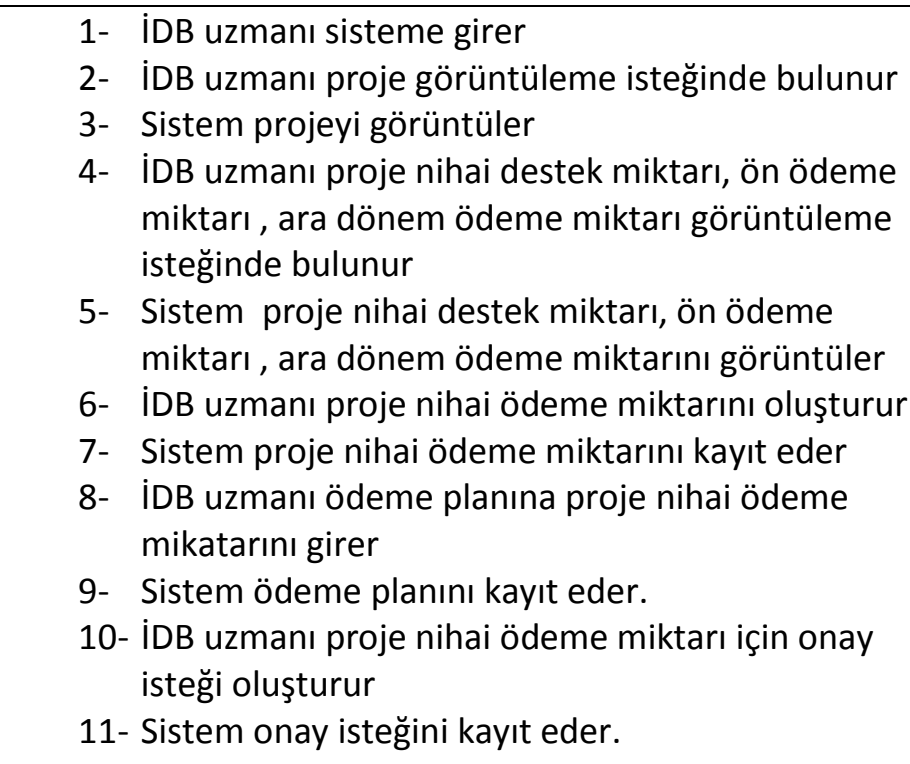 \\
\hline Extensions & $\begin{array}{l}\text { 6a - IDB uzmanı nihai ödeme miktarını değiştirmek ister } \\
\text { 2. Sistem değişiklikleri kayıt eder } \\
\text { 6b- iDB uzmanı nihai ödeme miktarını silmek ister } \\
\text { 2. Sistem değişiklikleri kayıt eder }\end{array}$ \\
\hline
\end{tabular}

\begin{tabular}{|l|l|}
\hline Use Case & \#2: Nihai ödeme miktarının onaylanması \\
\hline Primary Actor & GS uzmanı \\
\hline Stakeholders & GS uzmanı \\
\hline Minimal Guarantees & - \\
\hline Success Guarantees & Nihai ödeme gerçekleşti \\
\hline Preconditions & Nihai ödeme miktarı belirlendi. \\
\hline Triggers Scenario & $\begin{array}{r}\text { 1- GS sisteme girer } \\
\text { 2- GS onay isteklerini görüntüleme isteğinde bulunur }\end{array}$ \\
\hline Main &
\end{tabular}




\begin{tabular}{|c|c|}
\hline Success & $\begin{array}{l}\text { 3- } \begin{array}{l}\text { Sistem onay isteklerini görüntüler } \\
\text { 4- }\end{array} \text { GS proje nihai ödeme miktarı ve ödeme planı } \\
\text { görüntüleme isteğinde bulunur } \\
\text { 5- } \\
\text { Sistem proje nihai ödeme miktarı ve ödeme planı } \\
\text { görüntüler } \\
\text { 6- } \\
\text { 7- }\end{array}$ \\
\hline Extensions & $\begin{array}{l}\text { 6a - GS onay durumunu değiştirmek ister } \\
\text { 1. Sistem değişiklikleri kayıt eder } \\
\text { 6b- GS onay durumunu silmek ister } \\
\text { 1. Sistem değişiklikleri kayıt eder }\end{array}$ \\
\hline
\end{tabular}

\begin{tabular}{|c|c|}
\hline Use Case & \#9: Nihai ödeme miktarının hesap numarasına aktarılması \\
\hline Primary Actor & İDB uzmanı \\
\hline Stakeholders & İDB uzmanı \\
\hline Minimal Guarantees & - \\
\hline Success Guarantees & Proje nihai ödemesi gerçekleşti \\
\hline Preconditions & Nihai ödeme miktarı onaylandı \\
\hline Triggers & Toplam ödeme miktarı belirlendi \\
\hline $\begin{array}{l}\text { Main Scenario } \\
\text { Success }\end{array}$ & 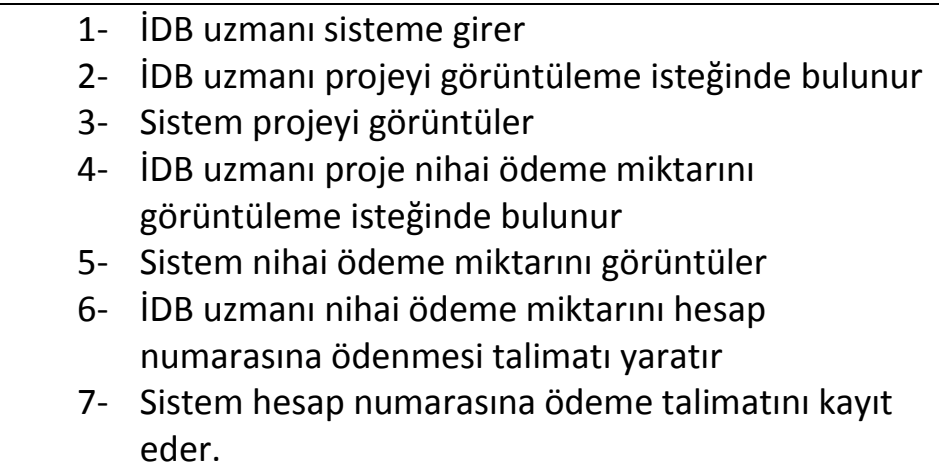 \\
\hline Extensions & $\begin{array}{l}\text { 6a- iDB uzmanı kalan eksi değerin ajans hesabına } \\
\text { ödenmesi talimatını yaratır } \\
\text { 1. Sistem geri ödeme talimatını kayıt eder } \\
\text { 2. iDB uzmanı yararlanıcıya geri ödeme miktarını } \\
\text { iletir } \\
\text { 3. Sistem yararlanıcıya uyarı mesajı atar, } \\
\text { yararlanıcıdan geri ödeme alınana kadar blok } \\
\text { işlemi gerçekleşir. }\end{array}$ \\
\hline
\end{tabular}




\begin{tabular}{|c|c|c|c|}
\hline FP\# & FP name & Data Mov. & OOI/Data Group \\
\hline \multirow[t]{28}{*}{1} & \multirow{28}{*}{$\begin{array}{ll}\text { Ödeme } & \text { oranlarının } \\
\text { belirlenmesi } & \end{array}$} & $\mathrm{E}$ & Ödeme oranları \\
\hline & & $E$ & Proje listesi \\
\hline & & $\mathrm{R}$ & Proje listesi \\
\hline & & $\mathrm{x}$ & Proje listesi \\
\hline & & $\mathrm{E}$ & Proje \\
\hline & & $\mathrm{R}$ & Proje \\
\hline & & $x$ & Proje \\
\hline & & $\mathrm{E}$ & Ödeme kontrol listesi \\
\hline & & $\mathrm{R}$ & Ödeme kontrol listesi \\
\hline & & $\mathrm{X}$ & Ödeme kontrol listesi \\
\hline & & $E$ & Proje uygun maliyetleri \\
\hline & & $\mathrm{R}$ & Proje uygun maliyetleri \\
\hline & & $x$ & Proje uygun maliyetleri \\
\hline & & $E$ & Ön ödeme risk puanı \\
\hline & & $R$ & Ön ödeme risk puanı \\
\hline & & $x$ & Ön ödeme risk puanı \\
\hline & & $E$ & Sözleşme dosyası \\
\hline & & $\mathrm{R}$ & Sözleşme dosyası \\
\hline & & $x$ & Sözleşme dosyası \\
\hline & & $E$ & Iş kuralları \\
\hline & & $\mathrm{R}$ & Iş kuralları \\
\hline & & $x$ & Iş kuralları \\
\hline & & $E$ & Ön ödeme miktarı \\
\hline & & W & Ön ödeme miktarı \\
\hline & & $E$ & Ödeme planı \\
\hline & & $\mathrm{W}$ & Ödeme planı \\
\hline & & $\mathrm{E}$ & Onay isteği \\
\hline & & W & Onay isteği \\
\hline \multirow[t]{5}{*}{2} & \multirow[t]{3}{*}{$\begin{array}{l}\text { Ön ödeme miktarı } \\
\text { listelenmesi }\end{array}$} & $\mathrm{E}$ & Ön ödeme miktarı \\
\hline & & $\mathrm{R}$ & Ön ödeme miktarı \\
\hline & & $x$ & Ön ödeme miktarı \\
\hline & \multirow[t]{2}{*}{$\begin{array}{l}\text { Ön ödeme miktarı } \\
\text { güncellenmesi }\end{array}$} & $\mathrm{E}$ & Ön ödeme miktarı \\
\hline & & $\mathrm{W}$ & Ön ödeme miktarı \\
\hline
\end{tabular}




\begin{tabular}{|c|c|c|c|}
\hline FP\# & FP name & Data Mov. & OOI/Data Group \\
\hline & & $F$ & \\
\hline & silinmesi & & \\
\hline & & W & Ön ödeme miktarı \\
\hline \multirow[t]{15}{*}{3} & \multirow{15}{*}{$\begin{array}{ll}\text { Ödeme } & \text { oranlarının } \\
\text { onaylanması } & \end{array}$} & $E$ & Onay isteği görüntüleme \\
\hline & & $E$ & Onay istekleri \\
\hline & & $\mathrm{R}$ & Onay istekleri \\
\hline & & $x$ & Onay istekleri \\
\hline & & $E$ & Onay isteği \\
\hline & & $R$ & Onay isteği \\
\hline & & $\mathrm{X}$ & Onay isteği \\
\hline & & $\mathrm{E}$ & Ön ödeme miktarı \\
\hline & & $R$ & Ön ödeme miktarı \\
\hline & & $x$ & Ön ödeme miktarı \\
\hline & & $E$ & Ödeme planı \\
\hline & & $R$ & Ödeme planı \\
\hline & & $x$ & Ödeme planı \\
\hline & & $E$ & Onay durumu \\
\hline & & W & Onay durumu \\
\hline \multirow[t]{7}{*}{4} & \multirow[t]{3}{*}{ Onay durumu listelenmesi } & $E$ & Onay durumu \\
\hline & & $R$ & Onay durumu \\
\hline & & $x$ & Onay durumu \\
\hline & \multirow{2}{*}{$\begin{array}{ll}\text { Onay } & \text { durumu } \\
\text { güncellenmesi } & \end{array}$} & $\mathrm{E}$ & Onay durumu \\
\hline & & W & Onay durumu \\
\hline & \multirow[t]{2}{*}{ Onay durumu silinmesi } & $\mathrm{E}$ & Onay durumu \\
\hline & & W & Onay durumu \\
\hline \multirow[t]{5}{*}{5} & \multirow{5}{*}{$\begin{array}{l}\text { Başvuru sahibinden ön } \\
\text { ödeme talebi alınması }\end{array}$} & $E$ & Talep alınması isteği \\
\hline & & $E$ & Ödeme talebi şartları \\
\hline & & $R$ & Ödeme talebi şartları \\
\hline & & $x$ & Ödeme talebi şartları \\
\hline & & $E$ & Ön ödeme talebi \\
\hline
\end{tabular}




\begin{tabular}{|c|c|c|c|}
\hline FP\# & FP name & Data Mov. & OOI/Data Group \\
\hline & & W & Ön ödeme talebi \\
\hline & & $E$ & Iş kuralları \\
\hline & & $R$ & Iş kuralları \\
\hline & & $x$ & Iş kuralları \\
\hline & & $E$ & Teminat \\
\hline & & W & Teminat \\
\hline \multirow[t]{5}{*}{6} & \multirow[t]{3}{*}{ Teminatın listelenmesi } & $\mathrm{E}$ & Teminat \\
\hline & & $R$ & Teminat \\
\hline & & $x$ & Teminat \\
\hline & \multirow[t]{2}{*}{ Teminatın güncellenmesi } & $E$ & Teminat \\
\hline & & $W$ & Teminat \\
\hline & \multirow[t]{2}{*}{ Teminatın silinmesi } & $E$ & Teminat \\
\hline & & $W$ & Teminat \\
\hline \multirow[t]{3}{*}{7} & \multirow{3}{*}{$\begin{array}{ll}\text { Ödeme } & \text { talebinin } \\
\text { listelenmesi } & \end{array}$} & $E$ & Ödeme talebi \\
\hline & & $\mathrm{R}$ & Ödeme talebi \\
\hline & & $x$ & Ödeme talebi \\
\hline & \multirow{2}{*}{$\begin{array}{ll}\text { Ödeme } & \text { talebinin } \\
\text { güncellenmesi } & \end{array}$} & $E$ & Ödeme talebi \\
\hline & & $\mathrm{W}$ & Ödeme talebi \\
\hline & \multirow[t]{2}{*}{ Ödeme talebinin silinmesi } & $\mathrm{E}$ & Ödeme talebi \\
\hline & & $W$ & Ödeme talebi \\
\hline \multirow[t]{9}{*}{8} & \multirow{9}{*}{$\begin{array}{lr}\text { Ön ödeme } & \text { miktarının } \\
\text { hesap } & \text { numarasına } \\
\text { aktarılması } & \end{array}$} & $E$ & Aktarım isteği \\
\hline & & $\mathrm{E}$ & Proje \\
\hline & & $\mathrm{R}$ & Proje \\
\hline & & $x$ & Proje \\
\hline & & $E$ & Ön ödeme miktarı \\
\hline & & $\mathrm{R}$ & Ön ödeme miktarı \\
\hline & & $x$ & Ön ödeme miktarı \\
\hline & & $E$ & Ön ödeme miktarı talimatı \\
\hline & & $\mathrm{W}$ & Ön ödeme miktarı talimatı \\
\hline
\end{tabular}




\begin{tabular}{|c|c|c|c|}
\hline FP\# & FP name & Data Mov. & OOI/Data Group \\
\hline \multirow[t]{22}{*}{9} & \multirow[t]{22}{*}{$\begin{array}{l}\text { Hakediş esasına göre ön } \\
\text { ödeme harcamalarını } \\
\text { değerlendirme }\end{array}$} & $E$ & Değerlendirme isteği \\
\hline & & $E$ & Proje \\
\hline & & $\mathrm{R}$ & Proje \\
\hline & & $\mathrm{x}$ & Proje \\
\hline & & $E$ & Eş finansman oranı \\
\hline & & $E$ & Ön ödeme miktarı \\
\hline & & $E$ & Ödeme talebi \\
\hline & & $\mathrm{E}$ & Ödeme planı \\
\hline & & $E$ & Ara dönem hakediş miktarı \\
\hline & & $E$ & Ödeme kontrol listesi \\
\hline & & $\mathrm{R}$ & Eş finansman oranı \\
\hline & & $\mathrm{R}$ & Ön ödeme miktarı \\
\hline & & $\mathrm{R}$ & Ödeme talebi \\
\hline & & $\mathrm{R}$ & Ödeme planı \\
\hline & & $\mathrm{R}$ & Ara dönem hakediş miktarı \\
\hline & & $\mathrm{R}$ & Ödeme kontrol listesi \\
\hline & & $x$ & Eş finansman oranı \\
\hline & & $x$ & Ön ödeme miktarı \\
\hline & & $x$ & Ödeme talebi \\
\hline & & $x$ & Ödeme planı \\
\hline & & $x$ & Ara dönem hakediş miktarı \\
\hline & & $x$ & Ödeme kontrol listesi \\
\hline \multirow[t]{13}{*}{10} & \multirow[t]{13}{*}{ Ön ödemenin kapatılması } & $E$ & Kapatılması isteği \\
\hline & & $E$ & Ödeme planı \\
\hline & & $E$ & Ön ödeme miktarı \\
\hline & & $\mathrm{E}$ & Ara dönem hakediş miktarı \\
\hline & & $E$ & Eş finansman oranı \\
\hline & & $\mathrm{R}$ & Ödeme planı \\
\hline & & $\mathrm{R}$ & Ön ödeme miktarı \\
\hline & & $\mathrm{R}$ & Ara dönem hakediş miktarı \\
\hline & & $\mathrm{R}$ & Eş finansman oranı \\
\hline & & $x$ & Ödeme planı \\
\hline & & $x$ & Ön ödeme miktarı \\
\hline & & $x$ & Ara dönem hakediş miktarı \\
\hline & & $\mathrm{x}$ & Eş finansman oranı \\
\hline
\end{tabular}




\begin{tabular}{|c|c|c|c|}
\hline FP\# & FP name & Data Mov. & OOI/Data Group \\
\hline & & W & Ödeme planı \\
\hline \multirow[t]{9}{*}{11} & \multirow{9}{*}{$\begin{array}{l}\text { Ön ödemede kalan } \\
\text { miktarın belirlenmesi }\end{array}$} & $E$ & Kalan miktar isteği \\
\hline & & $E$ & Ön ödeme miktarı \\
\hline & & $E$ & Ara dönem hakediş miktarı \\
\hline & & $\mathrm{R}$ & Ön ödeme miktarı \\
\hline & & $R$ & Ara dönem hakediş miktarı \\
\hline & & $x$ & Ön ödeme miktarı \\
\hline & & $x$ & Ara dönem hakediş miktarı \\
\hline & & $E$ & $\begin{array}{l}\text { Hakediş gerçekleşmemiş } \\
\text { miktar }\end{array}$ \\
\hline & & W & $\begin{array}{l}\text { Hakediş gerçekleşmemiş } \\
\text { miktar }\end{array}$ \\
\hline \multirow[t]{3}{*}{12} & \multirow[t]{3}{*}{$\begin{array}{l}\text { Hakediş gerçekleşmemiş } \\
\text { miktarın listelenmesi }\end{array}$} & $E$ & gerçekleşmemiş \\
\hline & & $R$ & gerçekleşmemiş \\
\hline & & $\mathrm{X}$ & gerçekleşmemiş \\
\hline & \multirow[t]{2}{*}{$\begin{array}{l}\text { Hakediş gerçekleşmemiş } \\
\text { miktarın güncellenmesi }\end{array}$} & $E$ & gerçekleşmemiş \\
\hline & & W & $\begin{array}{ll}\text { Hakediş } & \text { gerçekleşmemiş } \\
\text { miktar }\end{array}$ \\
\hline & \multirow[t]{2}{*}{$\begin{array}{l}\text { Hakediş gerçekleşmemiş } \\
\text { miktarın silinmesi }\end{array}$} & $\mathrm{E}$ & $\begin{array}{l}\text { Hakediş gerçekleşmemiş } \\
\text { miktar }\end{array}$ \\
\hline & & W & $\begin{array}{l}\text { Hakediş gerçekleşmemiş } \\
\text { miktar }\end{array}$ \\
\hline \multirow[t]{8}{*}{13} & \multirow[t]{8}{*}{$\begin{array}{l}\text { Ara ödeme miktarının } \\
\text { oluşturulması }\end{array}$} & $E$ & Ödeme miktarı isteği \\
\hline & & $E$ & Proje \\
\hline & & $\mathrm{R}$ & Proje \\
\hline & & $x$ & Proje \\
\hline & & $E$ & Eş finansman oranı \\
\hline & & $\mathrm{E}$ & Başvuru rehberi \\
\hline & & $E$ & Proje uygun maliyetleri \\
\hline & & $\mathrm{E}$ & Ödeme planı \\
\hline
\end{tabular}




\begin{tabular}{|c|c|c|c|}
\hline FP\# & FP name & Data Mov. & OOI/Data Group \\
\hline & & $\mathrm{R}$ & Eş finansman oranı \\
\hline & & $R$ & Başvuru rehberi \\
\hline & & $\mathrm{R}$ & Proje uygun maliyetleri \\
\hline & & $R$ & Ödeme planı \\
\hline & & $x$ & Eş finansman oranı \\
\hline & & $x$ & Başvuru rehberi \\
\hline & & $x$ & Proje uygun maliyetleri \\
\hline & & $\mathrm{X}$ & Ödeme planı \\
\hline & & $W$ & Ödeme planı \\
\hline & & $E$ & Onay isteği \\
\hline & & W & Onay isteği \\
\hline \multirow[t]{7}{*}{14} & \multirow[t]{3}{*}{ Onay isteği listelenmesi } & $E$ & Onay isteği \\
\hline & & $\mathrm{R}$ & Onay isteği \\
\hline & & $x$ & Onay isteği \\
\hline & \multirow[t]{2}{*}{ Onay isteği güncellenmesi } & $\mathrm{E}$ & Onay isteği \\
\hline & & W & Onay isteği \\
\hline & \multirow[t]{2}{*}{ Onay isteği silinmesi } & $\mathrm{E}$ & Onay isteği \\
\hline & & 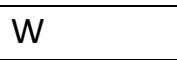 & Onay isteği \\
\hline \multirow[t]{13}{*}{15} & \multirow[t]{13}{*}{$\begin{array}{l}\text { Ara dönem ödeme } \\
\text { miktarının onaylanması }\end{array}$} & $E$ & Onama isteği \\
\hline & & $\mathrm{E}$ & Onay istekleri listesi \\
\hline & & $R$ & Onay istekleri listesi \\
\hline & & $x$ & Onay istekleri listesi \\
\hline & & $\mathrm{E}$ & Onay \\
\hline & & $\mathrm{R}$ & Onay \\
\hline & & $x$ & Onay \\
\hline & & $\mathrm{E}$ & Ara dönem ödeme miktarı \\
\hline & & $\mathrm{E}$ & Ödeme planı \\
\hline & & $R$ & Ara dönem ödeme miktarı \\
\hline & & $R$ & Ödeme planı \\
\hline & & $x$ & Ara dönem ödeme miktarı \\
\hline & & $x$ & Ödeme planı \\
\hline \multirow[t]{2}{*}{16} & \multirow[t]{2}{*}{ Onay durumu listelenmesi } & $\mathrm{E}$ & Onay durumu \\
\hline & & $R$ & Onay durumu \\
\hline
\end{tabular}




\begin{tabular}{|c|c|c|c|}
\hline \multirow[t]{2}{*}{ FP\# } & \multirow[t]{2}{*}{ FP name } & \multirow{2}{*}{$\frac{\text { Data Mov. }}{\mathrm{X}}$} & \multirow{2}{*}{$\begin{array}{l}\text { OOI/Data Group } \\
\text { Onay durumu }\end{array}$} \\
\hline & & & \\
\hline & \multirow{2}{*}{$\begin{array}{ll}\text { Onay } & \text { durumu } \\
\text { güncellenmesi } & \end{array}$} & $\mathrm{E}$ & Onay durumu \\
\hline & & W & Onay durumu \\
\hline & \multirow[t]{2}{*}{ Onay durumu silinmesi } & $\mathrm{E}$ & Onay durumu \\
\hline & & W & Onay durumu \\
\hline \multirow[t]{9}{*}{17} & \multirow[t]{9}{*}{$\begin{array}{ll}\text { Ara ödeme } & \text { miktarının } \\
\text { hesap } & \text { numarasına } \\
\text { aktarılması } & \end{array}$} & $E$ & Aktarım talebi \\
\hline & & $\mathrm{E}$ & Proje \\
\hline & & $R$ & Proje \\
\hline & & $x$ & Proje \\
\hline & & $\mathrm{E}$ & Ara ödeme miktarı \\
\hline & & $R$ & Ara ödeme miktarı \\
\hline & & $x$ & Ara ödeme miktarı \\
\hline & & $\mathrm{E}$ & Ara ödeme miktarı talimatı \\
\hline & & W & Ara ödeme miktarı talimatı \\
\hline \multirow[t]{18}{*}{18} & \multirow[t]{18}{*}{$\begin{array}{l}\text { Proje toplam uygun } \\
\text { maliyetlerin belirlenmesi }\end{array}$} & $E$ & Nihai maliyet belirleme isteği \\
\hline & & $\mathrm{E}$ & Proje \\
\hline & & $R$ & Proje \\
\hline & & $x$ & Proje \\
\hline & & $\mathrm{E}$ & Ön ödeme miktarı \\
\hline & & $\mathrm{E}$ & Ara dönem ödeme miktarı \\
\hline & & $E$ & Proje uygun maliyetleri \\
\hline & & $\mathrm{E}$ & Temel proje raporları \\
\hline & & $\mathrm{E}$ & Sözleşme dosyası \\
\hline & & $\mathrm{E}$ & Ödeme kontrol listesi \\
\hline & & $\mathrm{R}$ & Ön ödeme miktarı \\
\hline & & $R$ & Ara dönem ödeme miktarı \\
\hline & & $R$ & Proje uygun maliyetleri \\
\hline & & $\mathrm{R}$ & Temel proje raporları \\
\hline & & $R$ & Sözleşme dosyası \\
\hline & & $\mathrm{R}$ & Ödeme kontrol listesi \\
\hline & & $x$ & Ön ödeme miktarı \\
\hline & & $x$ & Ara dönem ödeme miktarı \\
\hline
\end{tabular}




\begin{tabular}{|c|c|c|c|}
\hline FP\# & FP name & Data Mov. & OOI/Data Group \\
\hline & & $\mathrm{X}$ & Proje uygun maliyetleri \\
\hline & & $x$ & Temel proje raporları \\
\hline & & $x$ & Sözleşme dosyası \\
\hline & & $x$ & Ödeme kontrol listesi \\
\hline & & $E$ & Proje nihai destek miktarı \\
\hline & & $W$ & Proje nihai destek miktarı \\
\hline \multirow[t]{5}{*}{19} & \multirow{3}{*}{$\begin{array}{l}\text { Proje nihai destek miktarı } \\
\text { listelenmesi }\end{array}$} & $E$ & Proje nihai destek miktarı \\
\hline & & $R$ & Proje nihai destek miktarı \\
\hline & & $x$ & Proje nihai destek miktarı \\
\hline & \multirow[t]{2}{*}{$\begin{array}{l}\text { Proje nihai destek miktarı } \\
\text { güncellenmesi }\end{array}$} & $E$ & Proje nihai destek miktarı \\
\hline & & W & Proje nihai destek miktarı \\
\hline & \multirow[t]{2}{*}{$\begin{array}{l}\text { Proje nihai destek miktarı } \\
\text { silinmesi }\end{array}$} & $E$ & Proje nihai destek miktarı \\
\hline & & W & Proje nihai destek miktarı \\
\hline \multirow[t]{8}{*}{20} & \multirow[t]{8}{*}{$\begin{array}{l}\text { Eş finansman oranında } \\
\text { nihai destek miktarının } \\
\text { indirilmesi }\end{array}$} & $E$ & Indirim isteği \\
\hline & & $\mathrm{E}$ & Başvuru rehberi \\
\hline & & $\mathrm{R}$ & Başvuru rehberi \\
\hline & & $x$ & Başvuru rehberi \\
\hline & & $E$ & Proje nihai destek miktarı \\
\hline & & $\mathrm{R}$ & Proje nihai destek miktarı \\
\hline & & $x$ & Proje nihai destek miktarı \\
\hline & & W & Proje nihai destek miktarı \\
\hline \multirow[t]{8}{*}{21} & \multirow[t]{8}{*}{$\begin{array}{ll}\text { Nihai } & \text { ödemenin } \\
\text { belirlenmesi } & \end{array}$} & $E$ & Nihai ödeme isteği \\
\hline & & $\mathrm{E}$ & Proje \\
\hline & & $R$ & Proje \\
\hline & & $x$ & Proje \\
\hline & & $\mathrm{E}$ & Business rule \\
\hline & & $\mathrm{R}$ & Business rule \\
\hline & & $x$ & Business rule \\
\hline & & $E$ & Proje nihai destek miktarı \\
\hline
\end{tabular}




\begin{tabular}{|c|c|c|c|}
\hline FP\# & FP name & Data Mov. & OOI/Data Group \\
\hline & & $\mathrm{E}$ & Ön ödeme miktarı \\
\hline & & $E$ & Ara dönem ödeme miktarı \\
\hline & & $\mathrm{E}$ & Ödeme planı \\
\hline & & $R$ & Proje nihai destek miktarı \\
\hline & & $\mathrm{R}$ & Ön ödeme miktarı \\
\hline & & $\mathrm{R}$ & Ara dönem ödeme miktarı \\
\hline & & $R$ & Ödeme planı \\
\hline & & $x$ & Proje nihai destek miktarı \\
\hline & & $x$ & Ön ödeme miktarı \\
\hline & & $x$ & Ara dönem ödeme miktarı \\
\hline & & $x$ & Ödeme planı \\
\hline & & W & Ödeme planı \\
\hline & & $E$ & Onay isteği \\
\hline & & $\mathrm{W}$ & Onay isteği \\
\hline & & $E$ & Proje nihai ödeme miktarı \\
\hline & & $W$ & Proje nihai ödeme miktarı \\
\hline \multirow[t]{7}{*}{22} & \multirow[t]{3}{*}{$\begin{array}{l}\text { Proje nihai ödeme miktarı } \\
\text { listelenmesi }\end{array}$} & $E$ & Proje nihai destek miktarı \\
\hline & & $R$ & Proje nihai destek miktarı \\
\hline & & $x$ & Proje nihai destek miktarı \\
\hline & \multirow[t]{2}{*}{$\begin{array}{l}\text { Proje nihai ödeme miktarı } \\
\text { güncellenmesi }\end{array}$} & $E$ & Proje nihai destek miktarı \\
\hline & & $W$ & Proje nihai destek miktarı \\
\hline & \multirow[t]{2}{*}{$\begin{array}{l}\text { Proje nihai ödeme miktarı } \\
\text { silinmesi }\end{array}$} & $E$ & Proje nihai destek miktarı \\
\hline & & $W$ & Proje nihai destek miktarı \\
\hline \multirow[t]{9}{*}{23} & \multirow[t]{9}{*}{$\begin{array}{l}\text { Nihai ödeme miktarının } \\
\text { onaylanması }\end{array}$} & $E$ & Onay \\
\hline & & $E$ & Onay istekleri \\
\hline & & $R$ & Onay istekleri \\
\hline & & $x$ & Onay istekleri \\
\hline & & $\mathrm{E}$ & Onay isteği \\
\hline & & $E$ & Ödeme planı \\
\hline & & $E$ & Proje nihai ödeme miktarı \\
\hline & & $R$ & Onay isteği \\
\hline & & $R$ & Ödeme planı \\
\hline
\end{tabular}




\begin{tabular}{|c|c|c|c|}
\hline FP\# & FP name & Data Mov. & OOI/Data Group \\
\hline & & $\mathrm{R}$ & Proje nihai ödeme miktarı \\
\hline & & $x$ & Onay isteği \\
\hline & & $\mathrm{X}$ & Ödeme planı \\
\hline & & $\mathrm{X}$ & Proje nihai ödeme miktarı \\
\hline & & $\mathrm{E}$ & Onay durumu \\
\hline & & W & Onay durumu \\
\hline \multirow[t]{7}{*}{24} & \multirow[t]{3}{*}{ Onay durumu listelenmesi } & $\mathrm{E}$ & Onay durumu \\
\hline & & $R$ & Onay durumu \\
\hline & & $\mathrm{X}$ & Onay durumu \\
\hline & \multirow[t]{2}{*}{$\begin{array}{ll}\text { Onay } & \text { durumu } \\
\text { güncellenmesi } & \end{array}$} & $E$ & Onay durumu \\
\hline & & W & Onay durumu \\
\hline & \multirow[t]{2}{*}{ Onay durumu silinmesi } & $E$ & Onay durumu \\
\hline & & $\mathrm{W}$ & Onay durumu \\
\hline \multirow[t]{12}{*}{25} & \multirow[t]{12}{*}{$\begin{array}{l}\text { Nihai ödeme miktarının } \\
\text { hesap r numarasına } \\
\text { aktarıması }\end{array}$} & $\mathrm{E}$ & Hesaba aktarım isteği \\
\hline & & $E$ & Proje \\
\hline & & $R$ & Proje \\
\hline & & $x$ & Proje \\
\hline & & $\mathrm{E}$ & Business rule \\
\hline & & $R$ & Business rule \\
\hline & & $x$ & Business rule \\
\hline & & $\mathrm{E}$ & Proje nihai ödeme miktarı \\
\hline & & $R$ & Proje nihai ödeme miktarı \\
\hline & & $x$ & Proje nihai ödeme miktarı \\
\hline & & $\mathrm{E}$ & Ödeme talimatı \\
\hline & & W & Ödeme talimatı \\
\hline \multirow[t]{6}{*}{26} & \multirow[t]{6}{*}{$\begin{array}{l}\text { Kalan eksi değerin ajans } \\
\text { hesabına aktarılması }\end{array}$} & $E$ & Hesaba aktarım isteği \\
\hline & & $E$ & Proje \\
\hline & & $\mathrm{R}$ & Proje \\
\hline & & $x$ & Proje \\
\hline & & $\mathrm{E}$ & Proje nihai ödeme miktarı \\
\hline & & $\mathrm{R}$ & Proje nihai ödeme miktarı \\
\hline
\end{tabular}




\begin{tabular}{|c|c|c|c|}
\hline FP\# & FP name & Data Mov. & OOI/Data Group \\
\hline & & $x$ & Proje nihai ödeme miktarı \\
\hline & & $E$ & $\begin{array}{l}\text { Ajans hesabına geri aktarım } \\
\text { talimatı }\end{array}$ \\
\hline & & W & $\begin{array}{l}\text { Ajans hesabına geri aktarım } \\
\text { talimatı }\end{array}$ \\
\hline 27 & Yararlanıcıdan geri ödeme & $E$ & Geri ödeme yapılması \\
\hline & & $\mathrm{E}$ & Proje geri ödeme miktarı \\
\hline & & $\mathrm{R}$ & Proje geri ödeme miktarı \\
\hline & & $x$ & Proje geri ödeme miktarı \\
\hline & & $E$ & Business rule \\
\hline & & $\mathrm{R}$ & Business rule \\
\hline & & $x$ & Business rule \\
\hline & Toplam CFP & 318 & \\
\hline
\end{tabular}

SORUN YÖNETIMI SÜRECI

\begin{tabular}{|c|c|}
\hline Use Case & \#1: Proje uygulama sorunu oluşturulması \\
\hline Primary Actor & IDB uzmanı \\
\hline Stakeholders & IDB uzmanı \\
\hline Minimal Guarantees & - \\
\hline Success Guarantees & Sorun kaydedildi \\
\hline Preconditions & - \\
\hline Triggers & $\begin{array}{l}\text { Sorun tespit edildi, yararlanıcıdan sorun geri bildirimi } \\
\text { yapıldı }\end{array}$ \\
\hline $\begin{array}{l}\text { Main Scenario } \\
\text { Success }\end{array}$ & $\begin{array}{l}\text { 1- } \text { IDB uzmanı sisteme girer } \\
\text { 2- } \\
\text { iDB uzmanı proje listesi görüntüleme isteğinde } \\
\text { bulunur } \\
\text { 3- } \\
\text { 4- } \\
\text { 5- } \\
\text { 5- Sistem projeleri görüntüler } \\
\text { 6- } \\
\text { iDB uzmanı proje uygulama sorunu oluşturur } \\
\text { dosyasını görüntüleme isteğinde bulunur. } \\
\text { 7- } \\
\text { Sistem proje uygulama sorunu ve sözleşme } \\
\text { dosyasını görüntüler } \\
\text { 8- iDB uzmanı proje uygulama sorunu raporunu } \\
\text { oluşturur. }\end{array}$ \\
\hline
\end{tabular}




\begin{tabular}{|c|c|}
\hline & $\begin{array}{l}\text { 9- Sistem proje uygulama sorunu raporunu kayıt } \\
\text { eder. }\end{array}$ \\
\hline Extensions & $\begin{array}{l}\text { 4a- IDB uzmanı proje uygulama sorunu listeleme isteğinde } \\
\text { bulunur } \\
\text { 1. Sistem proje uygulama sorunlarını listeler } \\
\text { 4b- iDB uzmanı proje uygulama sorunu güncelleme } \\
\text { isteğinde bulunur } \\
\text { 1. Sistem değişiklikleri kayıt eder } \\
\text { 4c- iDB uzmanı proje uygulama sorunu silme isteğinde } \\
\text { bulunur } \\
\text { 1. Sistem değişiklikleri kayıt eder } \\
\text { 8a- iDB uzmanı proje uygulama sorunu raporu listeleme } \\
\text { isteğinde bulunur } \\
\text { 2. Sistem proje uygulama sorunu raporlarını listeler } \\
\text { 8b- iDB uzmanı proje uygulama sorunu raporunu } \\
\text { güncelleme isteğinde bulunur } \\
\text { 2. Sistem değişiklikleri kayıt eder } \\
\text { 8c- iDB uzmanı proje uygulama sorunu raporunu silme } \\
\text { isteğinde bulunur } \\
\text { 2. Sistem değişiklikleri kayıt eder }\end{array}$ \\
\hline
\end{tabular}

\begin{tabular}{|c|c|}
\hline Use Case & \#2: Sorun uyarı mekanizmasının oluşturulması \\
\hline Primary Actor & iDB uzmanı \\
\hline Stakeholders & iDB uzmanı \\
\hline Minimal Guarantees & - \\
\hline Success Guarantees & Sorun uyarı mekaniması oluşturuldu \\
\hline Preconditions & Sorun değerlendirildi \\
\hline Triggers & Sorun değerlendirildi \\
\hline $\begin{array}{ll}\text { Main } & \text { Scenario } \\
\text { Success } & \end{array}$ & $\begin{array}{l}\text { 1- } \text { IDB uzmanı sisteme girer } \\
\text { 2- } \\
\text { iDB uzmanı Sorun uyarı mekanizması oluşturma } \\
\text { isteğinde bulunur. } \\
\text { 3- } \\
\text { 4- } \\
\text { iDBtem uyarı mekanizmaları seçeneğini listeler } \\
\text { isteğinde bulunur sorun mekanizması oluşturma } \\
\text { 5- } \\
\text { Sistem sözlü sorun mekanizması oluşturur. }\end{array}$ \\
\hline
\end{tabular}




\begin{tabular}{|c|c|}
\hline Extensions & $\begin{array}{l}\text { 4a IDB uzmanı erken uyarı mekanizması oluşturma } \\
\text { isteğinde bulnur } \\
\text { 1. Sistem erken uyarı mekanizmasını kayıt eder } \\
4 b \text { iDB uzmanı usulsüzlük mekanizması oluşturma } \\
\text { isteğinde bulnur } \\
\text { 1. Sistem usulsüzlük mekanizmasını kayıt eder. }\end{array}$ \\
\hline
\end{tabular}

\begin{tabular}{|c|c|}
\hline Use Case & \#3: Sözlü uyarı sonucunun takip edilmesi \\
\hline Primary Actor & İDB uzmanı \\
\hline Stakeholders & İDB uzmanı \\
\hline Minimal Guarantees & - \\
\hline Success Guarantees & Sorun belirlenen zamanda giderildi \\
\hline Preconditions & Sözlü uyarı mekanizması oluşturuldu \\
\hline \multicolumn{2}{|l|}{ Triggers } \\
\hline $\begin{array}{l}\text { Main Scenario } \\
\text { Success }\end{array}$ & $\begin{array}{l}\text { 1- } \text { iDB uzmanı sisteme girer. } \\
\text { 2- } \text { iDB uzmanı sözlü sorun takibi görüntüleme } \\
\text { isteğinde bulunur } \\
\text { 3- } \\
\text { 4- } \text { istem sözlü sorun takibini görüntüler } \\
\text { görüntüleme isteğinde bulunur } \\
\text { 5- } \begin{array}{l}\text { Sistem proje uygulama sorun raporunu } \\
\text { görüntüler. }\end{array} \\
\text { 6- } \\
\text { iDB uzmanı sorun aşamasını proje uygulama sorun } \\
\text { raporuna girer. } \\
\text { 7- } \begin{array}{l}\text { Sistem proje uygulama sorunu raporunu kayıt } \\
\text { eder. }\end{array}\end{array}$ \\
\hline Extensions & \\
\hline
\end{tabular}

\begin{tabular}{|l|l|}
\hline Use Case & $\begin{array}{l}\# 4: \text { Erken uyarıda izlenmesi gereken düzeltici tedbirlerin } \\
\text { hazırlanması }\end{array}$ \\
\hline Primary Actor & İzleme uzmanı \\
\hline Stakeholders & İzleme uzmanı \\
\hline
\end{tabular}




\begin{tabular}{|c|c|}
\hline Minimal Guarantees & - \\
\hline Success Guarantees & Erken uyarı çalışmaları gerçekleştirildi. \\
\hline Preconditions & Erken uyarı mekanizmasına karar verildi. \\
\hline \multicolumn{2}{|l|}{ Triggers } \\
\hline $\begin{array}{ll}\text { Main } & \text { Scenario } \\
\text { Success } & \end{array}$ & $\begin{array}{ll}\text { 1- } & \text { İleme uzmanı sisteme girer } \\
\text { 2- } & \text { İleme uzmanı sorunlu projeleri görüntüleme } \\
\text { isteğinde bulunur } \\
\text { 3- }\end{array}$ \\
\hline Extensions & 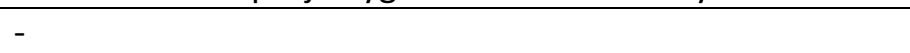 \\
\hline
\end{tabular}

\begin{tabular}{|c|c|}
\hline Use Case & \#5: Erken uyarı raporunun hazırlanması \\
\hline Primary Actor & İzleme uzmanı \\
\hline Stakeholders & İzleme uzmanı \\
\hline Minimal Guarantees & - \\
\hline Success Guarantees & Erken uyarı ön çalışmaları gerçekleştirildi. \\
\hline Preconditions & Erken uyarı raporu hazırlandı \\
\hline \multicolumn{2}{|l|}{ Triggers } \\
\hline $\begin{array}{ll}\text { Main Scenario } \\
\text { Success }\end{array}$ & $\begin{array}{l}\text { 1- } \\
\text { 2- } \\
\text { Izleme uzmanı sisteme uzmanı sorunlu projeleri görüntüleme } \\
\text { isteğinde bulunur } \\
\text { 3- }\end{array}$ \\
\hline
\end{tabular}




\begin{tabular}{|l|l|}
\hline Extensions & $\begin{array}{l}\text { 4a- izleme uzmanı erken uyarı raporu listeleme, } \\
\text { güncelleme ve silme isteğinde bulunur. }\end{array}$ \\
& $\begin{array}{l}\text { 8a- izleme uzmanı onay isteği listeleme, } \\
\text { güncelleme ve silme isteğinde bulunur. }\end{array}$ \\
\hline
\end{tabular}

\begin{tabular}{|c|c|}
\hline Use Case & \#6: Erken uyarı raporunun onaylanması \\
\hline Primary Actor & GS \\
\hline Stakeholders & GS \\
\hline Minimal Guarantees & - \\
\hline Success Guarantees & Erken uyarı raporu onaylandı \\
\hline \multicolumn{2}{|l|}{ Preconditions } \\
\hline \multicolumn{2}{|l|}{ Triggers } \\
\hline $\begin{array}{ll}\text { Main } & \text { Scenario } \\
\text { Success } & \end{array}$ & $\begin{array}{l}\text { 1- GS sisteme girer } \\
\text { 2- GS onay isteklerini görüntüleme isteğinde bulunur } \\
\text { 3- } \\
\text { 4- GStem onay isteklerini görüntüler } \\
\text { bulnur } \\
\text { 5- Sistem onay isteği detaylarını görüntüler } \\
\text { 6- GS erken uyarı raporunu görüntüleme isteğinde } \\
\text { bulunur } \\
\text { 7- Sistem erken uyarı raporunu görüntüler } \\
\text { 8- GS anlık izleme ziyareti oluşmaksızın onay durumu } \\
\text { oluşturur. } \\
\text { 9- Sistem onay durumunu kayıt eder }\end{array}$ \\
\hline Extensions & $\begin{array}{l}\text { 8a- GS anlık izleme durumu oluşturur } \\
\text { 1. Sistem anlık izleme durumunu kayıt eder } \\
\text { 2. İzleme uzmanı include: ANLIK IZLEME sonucunu } \\
\text { kayıt eder. } \\
\text { 8b- GS onay durumunu listeleme, güncellemek ve silme } \\
\text { isteğinde bulunur. }\end{array}$ \\
\hline
\end{tabular}




\begin{tabular}{|c|c|}
\hline Use Case & \#7: Erken uyarı raporu sorun giderilmesi \\
\hline Primary Actor & İzleme uzmanı \\
\hline Stakeholders & İzleme uzmanı \\
\hline Minimal Guarantees & - \\
\hline Success Guarantees & Sorun giderildi \\
\hline Preconditions & Erken uyarı raporu oluşturuldu \\
\hline \multicolumn{2}{|l|}{ Triggers } \\
\hline $\begin{array}{ll}\text { Main } & \text { Scenario } \\
\text { Success } & \end{array}$ & $\begin{array}{l}\text { 1- İleme uzmanı sisteme girer } \\
\text { 2- İzleme uzmanı Erken uyarı raporu görüntüleme } \\
\text { isteğinde bulunur } \\
\text { 3- } \\
\text { 4- İstem erken uyarı raporunu görüntüler } \\
\text { gönderir. } \\
\text { 5- } \\
\text { 6- İstem yararlanıcıya gönderildi bilgisini kayıt eder. } \\
\text { 7- Sistem yzmanırarlanıcı erken uyarı durum bilgisini } \\
\text { 8- İrüntüler. }\end{array}$ \\
\hline Extensions & $\begin{array}{l}\text { 7b - sistem erken uyarı sorunu düzeltilememe sebebini } \\
\text { görüntüler } \\
\text { 1. İzleme uzmanı erken uyarı durumunu görüntüleme } \\
\text { isteğinde bulunur } \\
\text { 2. Sistem erken uyarı durumunu görüntüler } \\
\text { 3. İzleme uzmanı erken uyarı raporu sorun bilgisini } \\
\text { oluşturur } \\
\text { 4. Sistem erken uyarı sorun bilgisini kayıt eder } \\
\text { 5. İzleme uzmanı erken uyarı onay isteği oluşturur } \\
\text { 5a- izleme uzmanı erken uyarı onayı listeleme, } \\
\text { güncelleme ve silme isteğinde bulunur. } \\
\text { 1. Sistem değişiklikleri kayıt eder. } \\
\text { 6. Sistem onay isteğini kayıt eder. }\end{array}$ \\
\hline
\end{tabular}




\begin{tabular}{|c|c|}
\hline Use Case & \#8: Sorun ile ilgili karar verilmesi \\
\hline Primary Actor & GS \\
\hline Stakeholders & GS \\
\hline Minimal Guarantees & - \\
\hline Success Guarantees & Erken uyarı işlemleri tamamlandı \\
\hline Preconditions & Ara veya nihai rapor incelenmesi tamamlandı \\
\hline Triggers & Proje ara ödemesi gerçekleşti \\
\hline $\begin{array}{ll}\text { Main } & \text { Scenario } \\
\text { Success } & \end{array}$ & $\begin{array}{l}\text { 1- GS sisteme girer } \\
\text { 2- GS erken uyarı raporu onay isteklerini görüntüler } \\
\text { 3- Sistem erken uyarı raporu onay isteklerini } \\
\text { görüntüler } \\
\text { 4- GS düzeltici tedbirlere devam edilmesi durumunu } \\
\text { oluşturur } \\
\text { 5- Sistem düzeltici tedbir durumunu kayıt eder }\end{array}$ \\
\hline Extensions & $\begin{array}{l}\text { 4a- GS usulsüzlük işlemleri mekanizması durumunu } \\
\text { oluşturur } \\
\text { 1- izleme uzmanı include : USULSÜZLÜK } \\
\text { MEKANIZMASI } \\
\text { 2- Sistem kayıt eder } \\
\text { 4b- GS sözleşmenin Feshi durumunu oluşturur. } \\
\text { 1- İzleme uzmanı include : SÖZLESSME FESHI } \\
\text { 4c- GS ödemenin durdurulması durumunu } \\
\text { oluşturur. } \\
\text { 1- GS sözleşme durumunu görüntüleme isteğinde } \\
\text { bulunur } \\
\text { 2- Sistem sözleşme durumunu görüntüler. } \\
\text { 3- GS sözleşme durumuna ödemenin } \\
\text { durdurulmasını girer } \\
\text { 4- Sistem ödemenin durdurulması durumunu } \\
\text { kayıt eder. }\end{array}$ \\
\hline
\end{tabular}

\begin{tabular}{|l|l|}
\hline Use Case & $\# 9:$ Usulsüzlük raporunun hazırlanması \\
\hline Primary Actor & izleme uzmanı \\
\hline Stakeholders & izleme uzmanı \\
\hline
\end{tabular}




\begin{tabular}{|c|c|}
\hline Minimal Guarantees & - \\
\hline Success Guarantees & Usulsüzlük raporu hazırlandı \\
\hline Preconditions & Usulsüzlük mekanizması uygun görüldü. \\
\hline \multicolumn{2}{|l|}{ Triggers } \\
\hline $\begin{array}{ll}\text { Main } & \text { Scenario } \\
\text { Success } & \end{array}$ & $\begin{array}{ll}\text { 1- } & \text { izleme uzmanı sisteme girer } \\
\text { 2- } & \text { izleme uzmanı usulsüzlük işlemlerine dair projeleri } \\
& \text { görüntüler } \\
\text { 3- } & \text { sistem usulsüzlük işlemi projesini görüntüler } \\
\text { 4- } & \text { izleme uzmanı proje uygulama sorun raporunu, } \\
& \text { proje uygulama sorun ve Ek I-15: usulsüzlük } \\
& \text { raporunu görüntüleme isteğinde bulunur. } \\
\text { 5- } & \text { Sistem proje uygulama sorun raporunu, proje } \\
& \text { uygulama sorun ve Ek I-15: usulsüzlük raporunu } \\
\text { görüntüler } & \\
\text { 6- } & \text { izleme uzmanı usulsüzlük raporu oluşturur } \\
\text { 7- } & \text { sistem usulsüzlük raporunu kayıt eder. } \\
\text { 8- } & \text { izleme uzmanı anlık izleme oluşturmaz } \\
\text { 9- } & \text { sistem anlık izleme oluşturulmadığını kayıt eder }\end{array}$ \\
\hline Extensions & $\begin{array}{l}\text { 8a izleme uzmanı anlık izleme oluşturur include: ANLIK } \\
\text { IZLEME use case } \\
\text { 1. sistem sonucu kayıt eder }\end{array}$ \\
\hline
\end{tabular}

\begin{tabular}{|c|c|}
\hline Use Case & \#2: Usulsüzlük durumunun değerlendirilmesi \\
\hline Primary Actor & GS \\
\hline Stakeholders & GS \\
\hline Minimal Guarantees & - \\
\hline Success Guarantees & - \\
\hline Preconditions & - \\
\hline Triggers & - \\
\hline $\begin{array}{ll}\text { Main } & \text { Scenario } \\
\text { Success } & \end{array}$ & $\begin{array}{l}\text { 1- GS sisteme girer } \\
\text { 2- GS usulsuzluk belirlenen projeleri görütüleme } \\
\text { isteğinde bulunur } \\
\text { 3- } \\
\text { 4- } \text { GS düzelticici tedbirlerin alınması̈ı isteğini yaratır } \\
\text { 5- }\end{array}$ \\
\hline Extensions & $\begin{array}{l}\text { 4a- GS usulsüzlük durumunu üptal eder } \\
\text { 1- Sistem usulsüzlük durumunu iptal edip, projenin } \\
\text { usulsüzlük değerini sıfırlar. }\end{array}$ \\
\hline
\end{tabular}


4b- GS sözleşmenin feshine karar verir

1- Sistem sözleşme fesih durumunu kayıt eder

\begin{tabular}{|c|c|}
\hline Use Case & \#9: İzlenmesi gereken düzeltici tedbirlerin alınması \\
\hline Primary Actor & izleme uzmanı \\
\hline Stakeholders & izleme uzmanı \\
\hline Minimal Guarantees & - \\
\hline Success Guarantees & İzlenmesi gereken düzeltici tedbirler hazırlandı. \\
\hline Preconditions & Durumun düzeltici tedbirlerle düzeltilmesine karar verildi \\
\hline Triggers & \\
\hline $\begin{array}{ll}\text { Main } & \text { Scenario } \\
\text { Success } & \end{array}$ & $\begin{array}{l}\text { 1- } \begin{array}{l}\text { İzleme uzmanı sisteme girer } \\
\text { 2- }\end{array} \text { İzleme uzmanı usulsüz projeleri görüntüleme } \\
\text { isteğinde bulunur } \\
\text { 3- }\end{array}$ \\
\hline Extensions & $\begin{array}{l}\text { 6a- izleme uzmanı proje uygulama sorun'u görüntüleme } \\
\text { isteğinde bulunur. } \\
\text { 1. Sistem düzeltici tedbir eklenmiş proje uygulama } \\
\text { sorun'unu görüntüler } \\
\text { 2. İzleme uzmanı sorun giderildi bilgisini ekler } \\
\text { 2a- sorun giderilmedi bilgisi eklenir } \\
\text { 1. GS uzmanı sözleşmeyi fesh eder. } \\
\text { 3. Sistem usulsüzlük işlemlerini tamamlar. }\end{array}$ \\
\hline
\end{tabular}

\begin{tabular}{|l|l|l|l|}
\hline FP\# & FP name & Data Mov. & OOI/Data Group \\
\hline 1 & $\begin{array}{l}\text { Proje uygulama sorunu } \\
\text { oluşturulması }\end{array}$ & $\mathrm{E}$ & Sorun oluşturma isteği \\
\cline { 3 - 4 } & & $\mathrm{E}$ & Proje listesi \\
\cline { 3 - 4 } & & $\mathrm{R}$ & Proje listesi \\
\cline { 3 - 4 } & $\mathrm{X}$ & Proje listesi \\
\cline { 3 - 4 } & $\mathrm{E}$ & Proje \\
\cline { 3 - 3 } & &
\end{tabular}




\begin{tabular}{|c|c|c|c|}
\hline FP\# & FP name & Data Mov. & OOI/Data Group \\
\hline & & $\mathrm{R}$ & Proje \\
\hline & & $\mathrm{x}$ & Proje \\
\hline & & $\mathrm{E}$ & Proje uygulama sorun \\
\hline & & W & Proje uygulama sorun \\
\hline \multirow[t]{15}{*}{2} & \multirow[t]{15}{*}{$\begin{array}{l}\text { Proje uygulama sorunu } \\
\text { raporu oluşturulması }\end{array}$} & $E$ & Sorun raporu isteği \\
\hline & & $\mathrm{E}$ & Proje \\
\hline & & $R$ & Proje \\
\hline & & $x$ & Proje \\
\hline & & $\mathrm{E}$ & Business rule \\
\hline & & $\mathrm{R}$ & Business rule \\
\hline & & $\mathrm{x}$ & Business rule \\
\hline & & $\mathrm{E}$ & Proje uygulama sorun \\
\hline & & $\mathrm{E}$ & Sözleşme dosyası \\
\hline & & $R$ & Proje uygulama sorun \\
\hline & & $R$ & Sözleşme dosyası \\
\hline & & $x$ & Proje uygulama sorun \\
\hline & & $\mathrm{x}$ & Sözleşme dosyası \\
\hline & & $\mathrm{E}$ & Proje uygulama sorunu raporu \\
\hline & & $W$ & Proje uygulama sorunu raporu \\
\hline 3 & $\begin{array}{l}\text { Proje uygulama sorun } \\
\text { raporu için listeleme, } \\
\text { güncelleme ve silme }\end{array}$ & $7 \mathrm{DM}$ & \\
\hline 4 & $\begin{array}{l}\text { Proje uygulama sorun } \\
\text { için } \\
\text { güncelleme ve silme }\end{array}$ & $7 \mathrm{DM}$ & \\
\hline \multirow[t]{6}{*}{5} & \multirow[t]{6}{*}{$\begin{array}{ll}\text { Sorun } & \text { uyarı } \\
\text { mekanizmasının } \\
\text { oluşturulması }\end{array}$} & $E$ & Sorun uyarı isteği \\
\hline & & $E$ & Sorun uyarı mekanizmları \\
\hline & & $\mathrm{R}$ & Sorun uyarı mekanizmları \\
\hline & & $x$ & Sorun uyarı mekanizmları \\
\hline & & $\mathrm{E}$ & Sorun tip belirleme \\
\hline & & W & Sorun tip belirleme \\
\hline 6 & Sözlü uyarı sonucunun & $E$ & Sözlü uyarı sonuç takip isteği \\
\hline
\end{tabular}




\begin{tabular}{|c|c|c|c|}
\hline FP\# & FP name & Data Mov. & OOI/Data Group \\
\hline \multirow{11}{*}{$1 \mathrm{rtH}$} & \multirow[t]{11}{*}{ izlenmesi } & & \\
\hline & & $E$ & Sözlü sorun listesi \\
\hline & & $R$ & Sözlü sorun listesi \\
\hline & & $x$ & Sözlü sorun listesi \\
\hline & & $\mathrm{E}$ & Proje uygulama sorun \\
\hline & & $\mathrm{E}$ & Proje uygulama sorunu rapor \\
\hline & & $R$ & Proje uygulama sorun \\
\hline & & $R$ & Proje uygulama sorunu rapor \\
\hline & & $\mathrm{X}$ & Proje uygulama sorun \\
\hline & & $\mathrm{X}$ & Proje uygulama sorunu rapor \\
\hline & & W & Proje uygulama sorunu rapor \\
\hline \multirow[t]{11}{*}{7} & \multirow{11}{*}{$\begin{array}{l}\text { Erken uyarıda izlenmesi } \\
\text { gereken düzeltici } \\
\text { tedbirlerin hazırlanması }\end{array}$} & $E$ & Düzeltici tedbirler isteği \\
\hline & & $E$ & Sorunlu proje \\
\hline & & $\mathrm{R}$ & Sorunlu proje \\
\hline & & $\mathrm{x}$ & Sorunlu proje \\
\hline & & $\mathrm{E}$ & Proje uygulama sorun \\
\hline & & $\mathrm{E}$ & Proje uygulama sorun rapor \\
\hline & & $R$ & Proje uygulama sorun \\
\hline & & $\mathrm{R}$ & Proje uygulama sorun rapor \\
\hline & & $x$ & Proje uygulama sorun \\
\hline & & $x$ & Proje uygulama sorun rapor \\
\hline & & W & Proje uygulama sorun \\
\hline \multirow[t]{12}{*}{8} & \multirow[t]{12}{*}{$\begin{array}{l}\text { Erken uyarı raporunun } \\
\text { hazırlanması }\end{array}$} & $E$ & Erken uyarı rapor isteği \\
\hline & & $\mathrm{E}$ & Sorunlu proje \\
\hline & & $R$ & Sorunlu proje \\
\hline & & $x$ & Sorunlu proje \\
\hline & & $\mathrm{E}$ & Iş kuralları \\
\hline & & $\mathrm{R}$ & Iş kuralları \\
\hline & & $\mathrm{x}$ & Iş kuralları \\
\hline & & $E$ & Proje uygulama sorun \\
\hline & & $E$ & Proje uygulama sorunu rapor \\
\hline & & $\mathrm{E}$ & Ek-13 erken uyarı raporu \\
\hline & & $R$ & Proje uygulama sorun \\
\hline & & $R$ & Proje uygulama sorunu rapor \\
\hline
\end{tabular}




\begin{tabular}{|c|c|c|c|}
\hline FP\# & FP name & Data Mov. & OOI/Data Group \\
\hline & & $\mathrm{R}$ & Ek-13 erken uyarı raporu \\
\hline & & $x$ & Proje uygulama sorun \\
\hline & & $x$ & Proje uygulama sorunu rapor \\
\hline & & $x$ & Ek-13 erken uyarı raporu \\
\hline & & $\mathrm{E}$ & Erken uyarı raporu \\
\hline & & W & Erken uyarı raporu \\
\hline \multirow[t]{6}{*}{9} & \multirow[t]{6}{*}{$\begin{array}{l}\text { Erken uyarı raporunun } \\
\text { onaya sunulması }\end{array}$} & $E$ & Onay isteği \\
\hline & & $E$ & Erken uyarı raporu \\
\hline & & $R$ & Erken uyarı raporu \\
\hline & & $x$ & Erken uyarı raporu \\
\hline & & $E$ & Onay isteği \\
\hline & & $W$ & Onay isteği \\
\hline 10 & $\begin{array}{l}\text { Erken uyarı raporu } \\
\text { listeleme, güncelleme ve } \\
\text { silme }\end{array}$ & $7 \mathrm{DM}$ & \\
\hline 11 & $\begin{array}{l}\text { Onay isteği listeleme, } \\
\text { güncelleme ve silme }\end{array}$ & $7 \mathrm{DM}$ & \\
\hline \multirow[t]{17}{*}{12} & \multirow[t]{17}{*}{$\begin{array}{l}\text { Erken uyarı raporunun } \\
\text { onaylanması }\end{array}$} & $E$ & Onaylama \\
\hline & & $E$ & Onay istekleri \\
\hline & & $\mathrm{R}$ & Onay istekleri \\
\hline & & $x$ & Onay istekleri \\
\hline & & E & Onay detayları \\
\hline & & $\mathrm{R}$ & Onay detayları \\
\hline & & $x$ & Onay detayları \\
\hline & & $\mathrm{E}$ & Iş kuralları \\
\hline & & $\mathrm{R}$ & Iş kuralları \\
\hline & & $x$ & Iş kuralları \\
\hline & & $E$ & Erken uyarı raporu \\
\hline & & $\mathrm{E}$ & Onay isteği \\
\hline & & $\mathrm{R}$ & Erken uyarı raporu \\
\hline & & $R$ & Onay isteği \\
\hline & & $x$ & Erken uyarı raporu \\
\hline & & $x$ & Onay isteği \\
\hline & & $\mathrm{E}$ & Onay durumu \\
\hline
\end{tabular}




\begin{tabular}{|c|c|c|c|}
\hline FP\# & FP name & Data Mov. & OOI/Data Group \\
\hline & & W & Onay durumu \\
\hline 13 & $\begin{array}{l}\text { Onay durumu listeleme, } \\
\text { güncelleme ve silme }\end{array}$ & $7 \mathrm{DM}$ & \\
\hline \multirow[t]{3}{*}{14} & \multirow{3}{*}{$\begin{array}{l}\text { Anlık izleme ziyareti } \\
\text { oluşturma }\end{array}$} & $E$ & Anlık izleme \\
\hline & & W & Anlık izleme \\
\hline & & W & Proje \\
\hline \multirow[t]{6}{*}{15} & \multirow[t]{6}{*}{$\begin{array}{l}\text { Erken uyarı raporu } \\
\text { sorun giderilmesi }\end{array}$} & $E$ & Erken uyarı gönderim isteği \\
\hline & & $\mathrm{E}$ & Erken uyarı raporu \\
\hline & & $\mathrm{R}$ & Erken uyarı raporu \\
\hline & & $\mathrm{x}$ & Erken uyarı raporu \\
\hline & & $\mathrm{E}$ & Erken uyarı-proje \\
\hline & & W & Erken uyarı-proje \\
\hline \multirow[t]{10}{*}{16} & \multirow[t]{10}{*}{$\begin{array}{l}\text { Erken uyarı } \\
\text { düzeltilememe durumu }\end{array}$} & $E$ & Erken uyarı düzeltme isteği \\
\hline & & $E$ & Erken uyarı durumu \\
\hline & & $\mathrm{R}$ & Erken uyarı durumu \\
\hline & & $x$ & Erken uyarı durumu \\
\hline & & $\mathrm{E}$ & Erken uyarı raporu \\
\hline & & $R$ & Erken uyarı raporu \\
\hline & & $\mathrm{X}$ & Erken uyarı raporu \\
\hline & & W & Erken uyarı raporu \\
\hline & & $\mathrm{E}$ & Onay isteği \\
\hline & & W & Onay isteği \\
\hline 17 & $\begin{array}{l}\text { Onay isteği listeleme, } \\
\text { güncelleme ve silme }\end{array}$ & $7 \mathrm{DM}$ & \\
\hline \multirow[t]{5}{*}{18} & \multirow[t]{5}{*}{$\begin{array}{l}\text { Düzeltici tedbirlere } \\
\text { devam edilmesi }\end{array}$} & $E$ & Karar isteği \\
\hline & & $\mathrm{E}$ & Erken uyarı onay isteği \\
\hline & & $\mathrm{R}$ & Erken uyarı onay isteği \\
\hline & & $x$ & Erken uyarı onay isteği \\
\hline & & $E$ & $\begin{array}{l}\text { Proje uygulama sorun-düzeltici } \\
\text { tedbirlere devam }\end{array}$ \\
\hline
\end{tabular}




\begin{tabular}{|c|c|c|c|}
\hline FP\# & FP name & Data Mov. & OOI/Data Group \\
\hline & & W & $\begin{array}{l}\text { Proje uygulama sorun-düzeltici } \\
\text { tedbirlere devam }\end{array}$ \\
\hline \multirow[t]{3}{*}{19} & \multirow{3}{*}{$\begin{array}{l}\text { Usulsüzlük mekanizması } \\
\text { oluşturma }\end{array}$} & $E$ & Usulsüzlük isteği \\
\hline & & $E$ & $\begin{array}{l}\text { Proje uygulama sorun- } \\
\text { usulsüzlük }\end{array}$ \\
\hline & & $\mathrm{W}$ & $\begin{array}{l}\text { Proje uygulama sorun- } \\
\text { usulsüzlük }\end{array}$ \\
\hline \multirow[t]{3}{*}{20} & \multirow[t]{3}{*}{ Sözleşme feshi } & $E$ & Sözleşme feshi isteği \\
\hline & & $E$ & $\begin{array}{l}\text { Proje uygulama sorun-sözleşme } \\
\text { feshi }\end{array}$ \\
\hline & & W & $\begin{array}{l}\text { Proje uygulama sorun-sözleşme } \\
\text { feshi }\end{array}$ \\
\hline \multirow[t]{5}{*}{21} & \multirow[t]{5}{*}{ Ödemenin durdurulması } & $E$ & $\begin{array}{l}\text { Sözleşme-ödeme durdurma } \\
\text { isteği }\end{array}$ \\
\hline & & $\mathrm{E}$ & Sözleşme durumu \\
\hline & & $\mathrm{R}$ & Sözleşme durumu \\
\hline & & $\mathrm{x}$ & Sözleşme durumu \\
\hline & & $W$ & Sözleşme durumu \\
\hline \multirow[t]{15}{*}{22} & \multirow[t]{15}{*}{$\begin{array}{l}\text { Usulsüzlük raporunun } \\
\text { hazırlanması }\end{array}$} & $E$ & Usulsüzlük rapor isteği \\
\hline & & $\mathrm{E}$ & Usulsüz-proje \\
\hline & & $\mathrm{R}$ & Usulsüz-proje \\
\hline & & $x$ & Usulsüz-proje \\
\hline & & $\mathrm{E}$ & Proje uygulama sorunu raporu \\
\hline & & $\mathrm{E}$ & Proje uygulama sorun \\
\hline & & $\mathrm{E}$ & Ek-15 usulsüzlük raporu \\
\hline & & $R$ & Proje uygulama sorunu raporu \\
\hline & & $\mathrm{R}$ & Proje uygulama sorun \\
\hline & & $\mathrm{R}$ & Ek-15 usulsüzlük raporu \\
\hline & & $x$ & Proje uygulama sorunu raporu \\
\hline & & $x$ & Proje uygulama sorun \\
\hline & & $x$ & Ek-15 usulsüzlük raporu \\
\hline & & $\mathrm{E}$ & Iş kuralları \\
\hline & & $\mathrm{R}$ & Iş kuralları \\
\hline
\end{tabular}




\begin{tabular}{|c|c|c|c|}
\hline FP\# & FP name & Data Mov. & OOI/Data Group \\
\hline & & $x$ & Iş kuralları \\
\hline & & $E$ & Usulsüzlük raporu \\
\hline & & $W$ & Usulsüzlük raporu \\
\hline \multirow[t]{3}{*}{23} & \multirow[t]{3}{*}{$\begin{array}{l}\text { Usulsüzlük anlık izleme } \\
\text { oluşturma }\end{array}$} & $E$ & Anlık izleme \\
\hline & & $E$ & Usulsüzlük rapor-anlık izleme \\
\hline & & W & Usulsüzlük rapor-anlık izleme \\
\hline 24 & $\begin{array}{l}\text { Usulsüzlük raporu } \\
\text { listeleme, güncelleme ve } \\
\text { silme }\end{array}$ & $7 \mathrm{DM}$ & \\
\hline \multirow[t]{10}{*}{25} & \multirow[t]{10}{*}{$\begin{array}{ll}\text { Usulsüzlük } & \text { durum } \\
\text { değerlendirme } & \end{array}$} & $E$ & $\begin{array}{ll}\text { Usulsüzlük } & \text { durum } \\
\text { değerlendirme } & \end{array}$ \\
\hline & & $E$ & Usulsüzlük durumu-proje \\
\hline & & $\mathrm{R}$ & Usulsüzlük durumu-proje \\
\hline & & $x$ & Usulsüzlük durumu-proje \\
\hline & & $E$ & Düzeltici tedbir \\
\hline & & $E$ & Usulsüzlük iptal \\
\hline & & $E$ & Sözleşme iptal \\
\hline & & W & Düzeltici tedbir \\
\hline & & W & Usulsüzlük iptal \\
\hline & & $W$ & Sözleşme iptal \\
\hline \multirow[t]{11}{*}{26} & \multirow[t]{11}{*}{$\begin{array}{l}\text { Durum düzeltici } \\
\text { tedbirler alınması }\end{array}$} & $E$ & Durum düzeltme \\
\hline & & $E$ & Usulsüz-proje \\
\hline & & $\mathrm{R}$ & Usulsüz-proje \\
\hline & & $x$ & Usulsüz-proje \\
\hline & & $E$ & Proje uygulama sorun \\
\hline & & $\mathrm{E}$ & Proje uygulama sorun raporu \\
\hline & & $\mathrm{R}$ & Proje uygulama sorun \\
\hline & & $\mathrm{R}$ & Proje uygulama sorun raporu \\
\hline & & $x$ & Proje uygulama sorun \\
\hline & & $x$ & Proje uygulama sorun raporu \\
\hline & & $\mathrm{W}$ & Proje uygulama sorun \\
\hline 27 & $\begin{array}{l}\text { Düzeltici tedbir eklenmiş } \\
\text { sözleşme feshi }\end{array}$ & $E$ & Fesih \\
\hline
\end{tabular}




\begin{tabular}{|l|l|l|l|}
\hline FP\# & FP name & Data Mov. & OOI/Data Group \\
\hline \multirow{3}{*}{} & \multirow{3}{*}{} & E & Proje uygulama sorun \\
\cline { 3 - 4 } & & R & Proje uygulama sorun \\
\cline { 3 - 4 } & & $\mathrm{X}$ & Proje uygulama sorun \\
\cline { 3 - 4 } & & $\mathrm{W}$ & Proje uygulama sorun \\
\cline { 3 - 4 } & & \\
\hline & Toplam CFP & 226 & \\
\hline
\end{tabular}

